\title{
Late Devonian-Carboniferous faulting and controlling structures and fabrics in NW Finnmark
}

\author{
Jean-Baptiste P. Koehl',2,3,4, Steffen G. Bergh 1,4, Per-Terje Osmundsen ${ }^{3,5,6}$, \\ Thomas F. Redfield7, Kjetil Indrevær ${ }^{8}$, Halldis Lea ${ }^{9} \&$ Espen Bergø ${ }^{10}$
}

${ }^{1}$ Department of Geosciences, UiT The Arctic University of Norway in Tromsø, N-9037 Tromsø, Norway.

${ }^{2}$ CAGE - Centre for Arctic Gas Hydrate, Environment and Climate, Department of Geosciences, UiT The Arctic University of Norway, Tromsø, Norway. ${ }^{3}$ Department of Geosciences, University of Oslo, P.O. Box 1047 Blindern, NO-0316 Oslo, Norway.

${ }^{4}$ Research Centre for Arctic Petroleum Exploration (ARCEx), UiT The Arctic University of Norway in Tromsø, N-9037 Tromsø, Norway.

${ }^{5}$ Department of Geoscience and Petroleum, NTNU-Norwegian University of Science and Technology, NO-7491 Trondheim, Norway.

${ }^{6}$ University Center in Svalbard, 9171 Longyearbyen, Norway.

${ }^{7}$ Geological Survey of Norway (NGU), Post Box 6315 Torgarden, 7491 Trondheim, Norway.

${ }^{8}$ Norges vassdrags- og energidirektorat, Vangsveien 73, Postboks 4223, 2307 Hamar, Norway.

${ }^{9}$ Equinor ASA, Forusbeen 50, 4035 Stavanger, Norway.

${ }^{10}$ Herøy Kommune, Rådhusgata 5, 6099 Fosnavåg, Norway.

E-mail corresponding author (Jean-Baptiste P. Koehl): jean-baptiste.koehl@uit.no

In the SW Barents Sea, Devonian-Carboniferous collapse led to the formation of major basins and faults, e.g., the Hammerfest Basin bounded by the Troms-Finnmark Fault Complex, and rhomboid- to sigma-shaped (half-)grabens on the Finnmark Platform. High-resolution aeromagnetic and bathymetry data from the shallow shelf show that analogue fault systems are present in coastal and onshore areas of NW Finnmark. We provide new documentation for the Langfjorden-Vargsundet fault, a post-Caledonian, NW-dipping, zigzag-shaped, margin-parallel fault complex consisting of alternating linear to sub-linear, NNE-SSW- and ENE-WSW-striking, down-NW normal fault segments. This fault formed as an extensional splay-fault of inverted, Caledonian, brittle-ductile thrusts, e.g, the Talvik and Kvenklubben faults, which the fault eventually truncated and offset. In northern Finnmark, the Langfjorden-Vargsundet fault is offset laterally by up to $28 \mathrm{~km}$ by a system of WNW-ESE-trending faults notably including potential segments and splays of the Trollfjorden-Komagelva Fault Zone, a reactivated Neoproterozoic, margin-orthogonal transfer fault, separating NW Finnmark from the eastern Finnmark Platform. This fault system likely dies out westwards, and portions of the system's process zone may crop out on the island of Magerøya. Similarly, the WNW-ESE- to ENE-WSW-striking Akkarfjord fault offsets the Langfjorden-Vargsundet fault by c. $2 \mathrm{~km}$ left-laterally. This fault may have formed as a conjugate to the Trollfjorden-Komagelva Fault Zone in Neoproterozoic (Timanian?) times. Steeply NW-plunging, upright and gently NE-plunging, inclined folds in Archaean-Palaeoproterozoic basement rocks and margin-parallel Caledonian thrusts may have controlled the formation and geometry of post-Caledonian faults. A Late Devonian-Carboniferous age for the Langfjorden-Vargsundet fault is supported by geochronological dating of onshore dykes and fault gouge, and by syn-tectonic sedimentary wedges along the offshore extension of the Langfjorden-Vargsundet fault. Mini-basins bounded by the LangfjordenVargsundet fault on the Finnmark Platform and on the shallow shelf, e.g., the Ryggefjorden trough, may represent analogues to deep, offshore, Devonian-Carboniferous basins, like the Nordkapp Basin, prior to the deposition of late Palaeozoic evaporites.

Keywords: inheritance, fault segment, fault splay, fault-tip process zone, inversion, Precambrian folds, Caledonian thrusts.

Received 11. April 2018 / Accepted 11. June 2019 / Published online 10. September 2019

Koehl, J.B.K., Bergh, S.G., Osmundsen, P.T., Redfield, T.F., Indrevær, K., Lea, H. \& Bergø, E. 2019: Late Devonian-Carboniferous faulting and controlling structures and fabrics in NW Finnmark. Norwegian Journal of Geology 99, 1-39. https://dx.doi.org/10.17850/njg99-3-5. 


\section{Introduction}

The North Atlantic passive margin off northern Norway and the Barents Sea evolved through multiple events of extension from the late Palaeozoic to the early Cenozoic that ended with continental breakup and seafloor spreading in the North Atlantic Ocean and the development of a transform plate margin extending from off the coasts of northern Norway to west Spitsbergen (Faleide et al., 1993, 2008; Doré et al., 1999; Cianfarra \& Salvini, 2015). The margin offshore Western Troms and NW Finnmark (Fig. 1) comprises the Finnmark Platform, a platform area adjacent to the onshore regions, and major NE-SW-trending, fault-bounded, deep offshore basins such as the Hammerfest and Nordkapp basins. These basins are bounded by major extensional faults like the Troms-Finnmark Fault Complex (Gabrielsen et al., 1990; Indrevær et al., 2013), while onshore fault complexes, like the SE-dipping Vestfjorden-Vanna Fault Complex, bound basement horsts such as the Lofoten Ridge and West Troms Basement Complex (Andresen \& Forslund, 1987; Forslund, 1988; Olesen et al., 1997; Bergh et al., 2010; Indrevær et al., 2013; Fig. 1). Another coastparallel major fault is the Langfjorden-Vargsundet fault (LVF; Zwaan \& Roberts, 1978; Worthing, 1984; Olesen et al., 1990; Roberts \& Lippard, 2005), a poorly studied fault that strikes overall NE-SW, dips dominantly to the NW and displays a zigzag-shaped pattern of alternating NNE-SSW- and ENE-WSW-striking faults in map view, similar to that of the Troms-Finnmark Fault Complex and Vestfjorden-Vanna Fault Complex (Fig. 1). We explore the possible northeastward continuation and linkage of the latter with the LVF. Furthermore, the SW Barents Sea margin is segmented by NW-SE-trending transfer fault zones, the Senja Fracture Zone and Fugløya transfer zone (Indrevær et al., 2013), which strike subparallel to the onshore Neoproterozoic-early Palaeozoic Trollfjorden-Komagelva Fault Zone (TKFZ) in eastern Finnmark (Siedlecki, 1980; Herrevold et al., 2009) and to the Kokelv Fault on the Porsanger Peninsula (Gayer et al., 1985; Lippard \& Roberts, 1987; Rice, 2014). The TKFZ is believed to continue farther west, off the coast where it is thought to interact with and merge into a WNWESE-trending fault segment of the Troms-Finnmark Fault Complex (Gabrielsen, 1984; Vorren et al., 1986; Gabrielsen \& Færseth, 1989; Gabrielsen et al., 1990; Roberts et al., 2011; Bergø, 2016; Lea, 2016).

The present study aims at providing a better correlation between brittle fault segments (individual fault surfaces with any scale length that are part of a set of subparallel faults forming a fault zone; Segall \& Pollard, 1980; Peacock et al., 2016) and splays (faults that merge with and are genetically related to another larger fault; Biddle \& Christie-Blick, 1985) of the LVF and TKFZ, and associated fault strands (individual fault of a set of closely spaced, (sub)parallel faults of a fault system; Biddle \& Christie-Blick, 1985) of both NE-SW- and
Figure 1. Regional tectonic map of the SW Barents Sea margin and North Norway (based on Bergh et al., 2007; Faleide et al., 2008; Hansen et al., 2012; Indrevor et al., 2013; Koehl et al., 2018a). Onshore geology is from Ramberg et al. (2008). The dashed frame locates Fig. 2. Black frame in lower left inset locates the Barents Sea on the Norwegian continental shelf. Abbreviations: A - Altafjorden, AFC - Asterias Fault Complex, Akf - Akkarfjord fault, AsW Altenes tectonic window, AW - Alta-Kvonangen tectonic window, BFC - Bjørnøyrenna Fault Complex, BKFC - Bothnian-Kvonangen Fault Complex, BSFC - Bothnian-Senja Fault Complex, FTZ Fugløya transfer zone, GL - Gjesvor Low, He - Helnes, K - Kvaløya, KF - Kokelv Fault, L - Langfjorden, Lf - Laksvatn fault, Lg Lygenfjorden, LR - Lofoten Ridge, LVF - Langfjorden-Vargsundet fault, Ma - Magerøya, Mf - Magerøysundet fault, MFC - Måsøy Fault Complex, NFC - Nysleppen Fault Complex, NP - Nordkinn Peninsula, PP - Porsanger Peninsula, Re - Repparfjorden, $R f$ - Rolvsøya fault, Rg - Ryggefjorden, Ri - Ringvassøya, RLFC - Ringvassøya-Loppa Fault Complex, Rv - Revsbotn, RW Repparfjord-Komagfjord tectonic window, S - Sørkjosen, SB - Sørver Basin, Se - Seiland, SFZ - Senja Fracture Zone, SISZ - Sørøya-Ingøya shear zone, Sj - Sjernøya, Sn - Snøjorden, sNB - southwesternmost Nordkapp basin, SP - Svorholt Peninsula, SSB - Senja Shear Belt, Sø - Sørøya, TFFC - Troms-Finnmark Fault Complex, TKFZ - Trollfjorden-Komagelva Fault Zone, Tu Tufjorden, V - Vargsundet, Va - Vannøya, VP - Varanger Peninsula, VVFC - Vestfjorden-Vanna Fault Complex.

WNW-ESE-striking fault systems in nearshore areas of NW Finnmark. We will discuss their possible link to late Palaeozoic faults and (half-)graben structures on the Finnmark Platform and within coastal fjords of NW Finnmark, e.g., in Ryggefjorden (Fig. 1), using field observations, fjord bathymetry and aeromagnetic data (Gernigon et al., 2014; Nasuti et al., 2015a). We characterise onshore fault and fracture geometries and kinematics, and discuss the formation and interaction of these structures in space and time as potential analogues for offshore fault systems. We specifically study two dominant fault systems in NW Finnmark striking NESW and WNW-ESE, including respectively the NESW-striking LVF and the WNW-ESE-striking TKFZ, and how faults of both systems link and interact to form rhomboid- to sigma-shaped, (half-)graben basins in nearshore fjords of NW Finnmark. Further, we discuss the architecture of the TKFZ and potentially associated splays and fault strands, possible similarities with adjacent WNW-ESE-striking faults, e.g., the Kokelv Fault on the Porsanger Peninsula (Fig. 1), and their potential continuation offshore to the northwest. We also discuss tentative factors that controlled the location of these major faults in basement and Caledonian host rocks (inheritance). We compare our results with offshore faults and basins on the Finnmark Platform and briefly discuss the geometry and potential linkage of segments and splays of the TKFZ with the Troms-Finnmark Fault Complex and related offshore basin-bounding faults (Gabrielsen \& Færseth, 1989; Roberts et al., 2011; Bergø, 2016; Lea, 2016). Finally, we present an alternative model for the geometry of the TKFZ and associated fault system off the coast of Finnmark in which segments and 


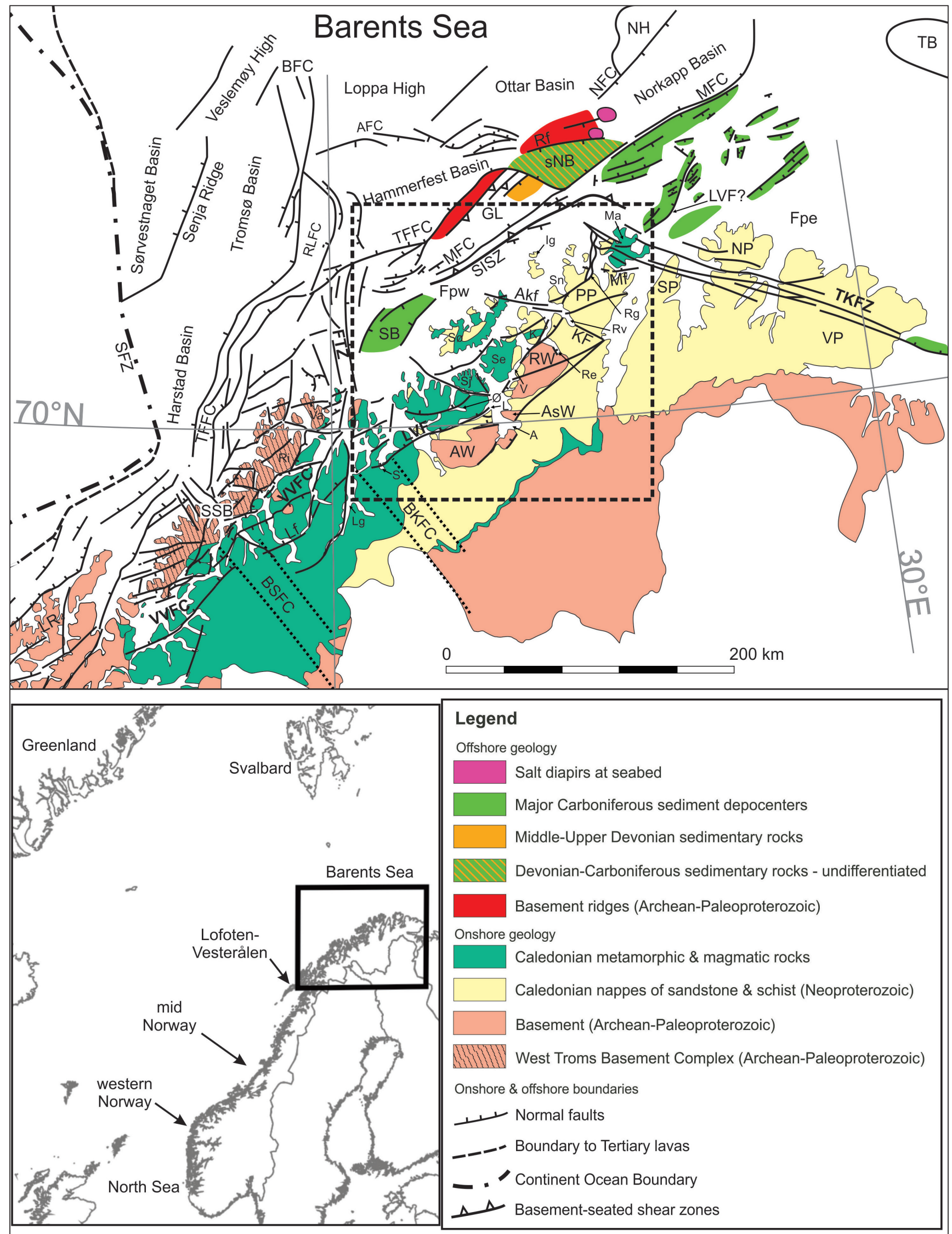

splays of the TKFZ and associated fault strands die out southeast of the Troms-Finnmark Fault Complex, and WNW-ESE-striking faults exposed onshore the island of Magerøya are part of the TKFZ and associated fault system (fault-tip) process zone (Vermilye \& Scholz, 1988; Braathen et al., 2013). 


\section{Geological setting}

Coastal areas in Western Troms and Finnmark along the SW Barents Sea margin (Fig. 1) consist of Neoarchaean to Palaeoproterozoic basement rocks (e.g., Zwaan, 1995; Bergh \& Torske, 1988; Bergh et al., 2010), partly preserved autochthonous Neoproterozoic rocks (Kirkland et al., 2008; Andresen et al., 2014) and a succession of Caledonian nappes (Andersen, 1981, 1984; Ramsay et al., 1985; Gayer et al., 1987; Fig. 1). Basement rocks in NW Finnmark are exposed within tectonic windows as horsts and ridges, e.g., the Alta-Kvænangen (Bøe \& Gautier, 1978; Zwaan \& Gautier, 1980), Altenes and RepparfjordKomagfjord tectonic windows (Pharaoh et al., 1982, 1983; Gayer et al., 1987; Bergh \& Torske, 1988; Jensen, 1996; Torgersen \& Viola, 2014; Torgersen et al., 2015). Neoproterozoic and Caledonian metasedimentary and meta-igneous rocks dominate on the shallow shelf and onshore areas (Indrevær \& Bergh, 2014; Fig. 1). These rocks belong to the Kalak Nappe Complex, the Magerøy Nappe and the Seiland Igneous Province (Ramsay et al., 1979, 1985; Andersen, 1981, 1984; Kirkland et al., 2005; Corfu et al., 2006). On the Finnmark Platform, successions of late Palaeozoic to Cenozoic sedimentary basins and highs formed during the collapse of the Caledonides and subsequent rifting of the NE Atlantic Ocean (Samuelsberg et al., 2003; Koehl et al., 2018a).

\section{Precambrian and Caledonian geology}

In the study area, Palaeoproterozoic rocks crop out in the Altenes, Repparfjord-Komagfjord (Pharaoh et al., 1982, 1983; Bergh \& Torske, 1988; Jensen, 1996) and AltaKvænangen (Bøe \& Gautier, 1978; Zwaan \& Gautier, 1980; Gautier et al., 1987) tectonic windows (Fig. 1). The basement suite of the Altenes and Alta-Kvænangen tectonic windows consists of low-grade metavolcanics and metasedimentary rocks of the Raipas Supergroup (Bergh \& Torske, 1986, 1988; Melezhik et al., 2015). These basement rocks are deformed by km-scale, steeply NW-plunging folds (Zwaan \& Gautier, 1980; Gautier et al., 1987), which show similar trend and wavelength as Precambrian fold structures in the West Troms Basement Complex (Bergh et al., 2010). Palaeoproterozoic basement rocks of the Repparfjord-Komagfjord tectonic window display slightly higher metamorphic grades and are deformed by $\mathrm{km}$-scale, gently NE-plunging Svecofennian folds (Reitan, 1963; Pharaoh et al., 1982, 1983; Torgersen \& Viola, 2014).

Caledonian rocks of the Kalak Nappe Complex make up most of the coastal region of NW Finnmark and include Proterozoic basement rocks, metasedimentary rocks, and plutons of the Seiland Igneous Province (Robins \& Gardner, 1975; Corfu et al., 2014). On the Porsanger Peninsula, the Kalak Nappe Complex consists of amphibolite-facies psammites, paragneisses and schists with a well-developed foliation and low-angle thrusts striking NE-SW and dipping gently northwestward (Ramsay et al., 1979, 1985; Gayer et al., 1987; Corfu et al., 2014). Internal nappe fabrics include a prominent gently $\mathrm{NW}$-dipping foliation, east-verging, NNE-SSW-trending, recumbent folds, a major low-angle basal thrust zone and subsidiary thrusts that accommodated top-ESE thrusting (Ramsay et al., 1985; Townsend, 1987b; Kirkland et al., 2005).

The Seiland Igneous Province (580-560 Ma; Roberts et al., 2006, 2010) is made up of mafic-ultramafic plutons related to the rifting of the Iapetus Ocean (Gardner \& Robins, 1975; Elvevold et al., 1994; Siedlecka et al., 2004; Corfu et al., 2014). New geophysical studies show that the Seiland Igneous Province is characterised by two deep-reaching roots below the islands of Seiland and Sørøya, revealing a maximum $10 \mathrm{~km}$ thickness for the Kalak Nappe Complex (Pastore et al., 2016). In addition, many thrust sheets in coastal areas of NW Finnmark show ENE-WSW- to NNE-SSW-trending metadolerite dykes of latest Cryogenian-Ediacaran age (K-Ar dating from Beckinsale et al., 1975 and Rice et al., 2004). These dykes are also linked to the rifting of the Iapetus Ocean (Roberts, 1972; Siedlecka et al., 2004; Nasuti et al., 2015a).

Late Ordovician to early Silurian greenschist-facies schists and metavolcanic units of the Magerøy Nappe crop out on the island of Magerøya, northeastern Sørøya and on the Porsanger Peninsula (Fig. 1; Andersen, 1981, 1984; Kirkland et al., 2005, 2007; Corfu et al., 2014) and are intruded by ultramafic and gabbroic-e.g., the Honningsvåg Suite (or Honningsvåg Igneous Complex; Robins et al., 1987; Robins, 1998; Corfu et al., 2006) —and granitic plutons-e.g., the Finnvik Granite (Andersen, 1981). Major structures in the Magerøy Nappe include NNE-SSW-trending, east-verging, asymmetric folds and NE-SW-trending, low-angle, Caledonian foliation and ductile thrusts (Andersen, 1981).

\section{Brittle faults and margin architecture}

\section{Post-Caledonian offshore basins}

From the end of the Caledonian Orogeny to the breakup of the NE Atlantic, the SW Barents Sea experienced multiple pulses of extension that began during extensional collapse of the Caledonides in the DevonianCarboniferous (Gudlaugsson et al., 1998; Gernigon et al., 2014; Koehl et al., 2018a). Late-post-orogenic collapse led to the exhumation of a regional, onshore-offshore core complex running from Lofoten-Vesterålen (Hames \& Andresen, 1996; Klein \& Steltenpohl, 1999; Klein et al., 1999; Steltenpohl et al., 2004, 2011; Henstra \& Rotevatn, 2014) to the Barents Sea (Koehl et al., 2018a), and possibly similar to core complexes in Mid Norway (Osmundsen et al., 2005). Core complex exhumation in Lofoten-Vesterålen is thought to have occurred along inverted Caledonian shear zones (Steltenpohl et al., 
2011), which may represent onshore analogues to the newly recorded Sørøya-Ingøya shear zone in the SW Barents Sea (Koehl et al., 2018a). This large-scale shear zone defines a large spoon-shaped trough that may have controlled formation of major, Devonian-Carboniferous, rhomboid to sigma-shaped basins offshore such as the southwesternmost part of the Nordkapp Basin (Koehl et al., 2018a) and minor (half-) grabens on the Finnmark Platform (Samuelsberg et al., 2003; Rafaelsen et al., 2008; Koehl et al., 2018a; Fig. 1), which are potential analogues to Middle Devonian collapse basins in western (Séranne et al., 1989; Chauvet \& Séranne, 1994; Wilks \& Cuthbert, 1994; Osmundsen \& Andersen, 2001) and Mid Norway (Braathen et al., 2000). This collapse phase may have lasted until the mid/late Carboniferous, initiating the formation of large sedimentary basins, like the Nordkapp, Hammerfest and Ottar basins (Dengo \& Røssland, 1992; Breivik et al., 1995; Gudlaugsson et al., 1998; Indrevær et al., 2013), and was possibly followed by a subsequent episode of rifting in the late Carboniferous(?)-early/mid Permian (Davids et al., 2013; Koehl et al., 2018b).

\section{Post-Caledonian faults and fractures}

Middle to Late Devonian-Carboniferous basins in the SW Barents Sea (Larssen et al., 2002; Samuelsberg et al., 2003; Koehl et al., 2018a) are bounded by zigzagshaped fault complexes composed of ENE-WSW- to NNE-SSW-striking arcuate normal faults (Gabrielsen et al., 1990; Doré et al., 1999; Faleide et al., 2008; Indrevær et al., 2013). An example near the coasts of Troms and Finnmark is the NW-dipping Troms-Finnmark Fault Complex, which terminates as a NNE-dipping fault, separating the western Finnmark Platform from the southwesternmost Nordkapp basin (Fig. 1; Gabrielsen et al., 1990; Koehl et al., 2018a). Another example is the Måsøy Fault Complex (Fig. 1; Gabrielsen et al., 1990) that bounds the southwesternmost Nordkapp basin and the Nordkapp Basin to the southeast. The main segment of this fault complex may have formed as a brittle splayfault during inversion of the Sørøya-Ingøya shear zone in the Mid-Late Devonian-early Carboniferous (Koehl et al., 2018a).

In onshore areas, zigzag-shaped, post-Caledonian normal faults are present in Lofoten-Vesterålen (Bergh et al., 2007; Eig, 2008; Eig \& Bergh, 2011; Hansen \& Bergh, 2012; Hansen et al., 2012), western Troms (Indrevær et al., 2013; Davids et al., 2013) and NW Finnmark (Roberts, 1971; Worthing, 1984; Lippard \& Roberts, 1987; Townsend, 1987a; Rykkelid, 1992; Lippard \& Prestvik, 1997; Roberts \& Lippard, 2005). A characteristic example is the onshore-nearshore, SE-dipping VestfjordenVanna Fault Complex that can be traced from Lofoten to western Troms as the contact between Precambrian basement rocks and downthrown Caledonian Nappes (Fig. 1; Indrevær et al., 2013). An example in NW Finnmark is the LVF. This NW-dipping fault complex presumably downthrows Caledonian rocks to the northwest, thus explaining the abrupt transition from
Palaeoproterozoic rocks of the Repparfjord-Komagfjord, Altenes and Alta-Kvænangen tectonic windows in the southeast to rocks of the Kalak Nappe Complex and Seiland Igneous Province in the northwest across Langfjorden and Vargsundet (Fig. 1; Zwaan \& Roberts, 1978). Apart from a study onshore the island of Seiland (Worthing, 1984), the geometry, kinematics, timing of formation and linkage of this fault complex are poorly studied and remain uncertain.

Onshore studies of post-Caledonian brittle faults in Finnmark show that the Kvenklubben fault, a major brittle-ductile, NW-dipping fault potentially merging with the LVF at depth and bounding the Caledonian Kalak Nappe Complex from basement rocks of the Repparfjord-Komagfjord tectonic window, acted as a Caledonian thrust and was reactivated as a normal fault during post-Caledonian extension (Torgersen \&

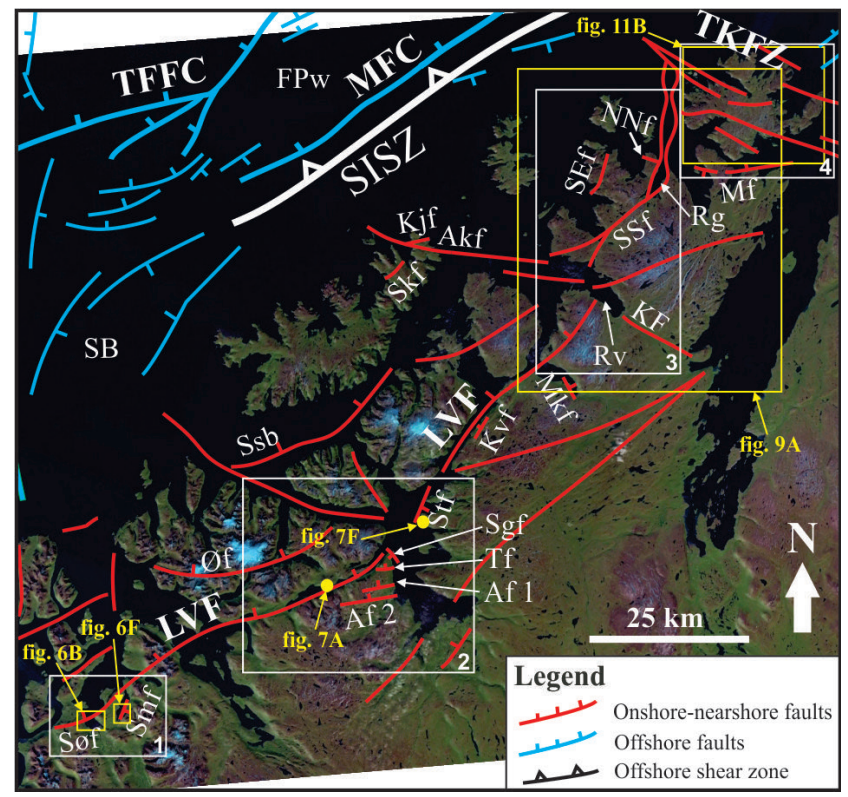

Figure 2. Satellite image of NW Finnmark showing major onshore and nearshore brittle faults belonging to the LVF and to the TKFZ and associated margin-oblique fault system. The map combines onshore faults from the present study and from Roberts (1971), Zwaan \& Roberts (1978), Gayer et al. (1985), Townsend (1987a), Lippard \& Roberts (1987), Rykkelid (1992), Marti (2013) and Torgersen et al. (2014). Offshore faults are from Indrevoer et al. (2013) and Koehl et al. (2018a). Satellite images of onshore areas are from www.norgei3d.no. See Fig. 1 for location. White boxes labelled 1-4 show the location of fault data acquired during fieldwork and displayed in stereo diagrams in Fig. 3. Abbreviations: Af 1 - Altafjorden fault 1, Af 2 - Altafjorden fault 2, Akf-Akkarfjord fault, FPw - western Finnmark Platform, KF - Kokelv Fault, Kjf - Kjøtvika fault, Kvf - Kvenklubben fault, LVF - Langfjorden-Vargsundet fault, $M f$ - Magerøysundet fault, MFC - Måsøy Fault Complex, Mkf - Markopp fault, NNf - Njoal-Neset fault, Rg - Ryggefjorden, Rv - Revsbotn, SB - Sørvor Basin, SEf - Selvika-Eiterfjorden fault, Sgf - Storhaugen fault, SISZ - Sørøya-Ingøya shear zone, Skf - Skarvdalen fault, Smf - Straumfjordbotn fault, Ssb - Sørøy sub-basin, SSf - SnøfjordenSlatten fault, Stf - Storekorsnes fault, Søf - Sørkjosen fault, Tf - Talvik fault, TFFC - Troms-Finnmark Fault Complex, TKFZ - TrollfjordenKomagelva Fault Zone, Øf-Øksfjorden fault. 
Viola, 2014; Torgersen et al., 2014). Farther north, on the Porsanger Peninsula (Fig. 1), Townsend (1987a) described several post-Caledonian normal faults including the Snøfjorden-Slatten (Passe, 1978), the Njoal Neset and the Selvika-Eiterfjorden faults (Hayes, 1980; Fig. 2). Between the island of Magerøya and the Porsanger Peninsula, a major, down-NNW, normal fault, the Magerøysundet fault, was observed during the construction of a subsea tunnel (Rykkelid, 1992). Andersen (1981) suggested that the Magerøynsundet fault extends northwestwards as a NNE-dipping normal fault (Figs. 1 \& 2), thus explaining the preservation (downthrowing) of rocks of the Magerøya Nappe onshore Magerøya.

\section{Post-Caledonian transfer fault zones}

The Lofoten-Vesterålen and SW Barents Sea margins are segmented by margin-oblique (i.e., oblique to the Atlantic margin of Norway), NNW-SSE- to WNW-ESE-striking transfer fault zones (Gabrielsen, 1984; Siedlecka, 1985; Gabrielsen \& Færseth, 1989; Faleide et al., 2008; Eig \& Bergh, 2011; Indrevær et al., 2013; Gernigon et al., 2014). The largest of these is the offshore De Geer Zone (Faleide et al., 2008; Cianfarra \& Salvini, 2015) separating the SW Barents Sea and Lofoten-Vesterålen margins. This transfer zone merges southwards into the Senja Fracture Zone along basement-seated weakness zones, like the Senja Shear Belt and Bothnian-Senja Fault Complex (Zwaan, 1995). These basement weakness zones account for switches of polarity along major normal faults, e.g., the Vestfjorden-Vanna Fault Complex (Fig. 1; Olesen et al., 1993, 1997). Farther north, Indrevær et al. (2013) described attitude changes of the Vestfjorden-Vanna Fault Complex across the Fugløya transfer zone (Fig. 1), and argued that the Vestfjorden-Vanna Fault Complex connects with the offshore Måsøy and Nysleppen fault complexes (Fig. 1). Northeastwards, the Tiddlybanken Basin (Mattingsdal et al., 2015) developed along WNWESE-striking faults segmenting the Nordkapp Basin (Fig. $1)$.

In NW Finnmark, a potential candidate to represent a transfer zone is the Neoproterozoic-early Palaeozoic, WNW-ESE-striking TKFZ (Siedlecki, 1980; Siedlecka, 1985; Herrevold et al., 2009), which crops out on the Varanger Peninsula and can be traced eastsoutheastwards on fjord bathymetry and seismic profiles (Roberts et al., 2011; Fig. 1), and onto the Rybachi and Sredni peninsulas in NW Russia where it was mapped as a single-segment fault with a $130 \mathrm{~m}$-wide zone of cataclasite and gouge (Roberts, 1995; Roberts \& Karpuz, 1995; Karpuz et al., 1995). On the Varanger Peninsula, the TKFZ splays into several sub-parallel fault segments and splays bounding duplex structures (Siedecka \& Siedlecki, 1967; Siedlecka, 1975; Siedlecka, 1985; Herrevold et al., 2009). Westwards, the TKFZ is thought to proceed offshore, into the Barents Sea, where it supposedly merges with a WNW-ESE-striking segment of the Troms-Finnmark Fault Complex, forming triangular- shaped mini-basins (Gabrielsen, 1984; Vorren et al., 1986; Townsend, 1987a; Gabrielsen \& Færseth, 1989; Gabrielsen et al., 1990; Roberts et al., 2011; Bergø, 2016; Lea, 2016). The TKFZ initially formed as a major, basinbounding, normal fault in the Neoproterozoic (Rice et al., 1989) and was later reactivated as a sinistralreverse oblique-slip fault during the Timanian Orogeny (Siedlecka \& Siedlecki, 1967; Roberts \& Olovyanishnikov, 2004). A paleomagnetic study and a recent restoration model constrains maximum Caledonian reactivation along the TKFZ to $207 \mathrm{~km}$ of dextral strike-slip movement (Bylund, 1994; Rice, 2014).

Other subsidiary potential transfer fault zones in NW Finnmark include the Kokelv Fault, a NNE-dipping fault inferred from abrupt changes in metamorphic grades in Caledonian nappe units (Gayer et al., 1985; Lippard \& Roberts, 1987), the WNW-ESE- to ENE-WSW-striking Akkarfjord fault in northeastern Sørøya (Fig. 1; Roberts, 1971) and the Markopp fault in Repparfjorden (Fig. 1), an ENE-dipping, low-angle brittle fault located near the contact between Precambrian rocks of the RepparfjordKomagfjord tectonic window and Caledonian rocks of the Kalak Nappe Complex (Figs. 1 \& 2; Torgersen et al., 2014). Also of interest, sets of ENE-WSW/NE-SW- (e.g., Kjøtvika and Skarvdalen faults; Fig. 2) and WNW-ESE/ NW-SE-striking strike-slip to oblique-slip faults on the island of Seiland (Worthing, 1984) and in northeastern Sørøya (Fig. 1; Roberts, 1971) may have formed as conjugate, dominantly strike-slip fracture sets due to WNW-ESE-oriented maximum stress.

\section{Absolute dating of post-Caledonian faults}

Age constraints for post-Caledonian faulting in NW Finnmark are provided by a few geochronological studies. First, lateral escape near the end of the Caledonian Orogeny was dated to 431-428 Ma using U$\mathrm{Pb}$ and $\mathrm{Ar}-\mathrm{Ar}$ geochronology and provide a maximum age for post-Caledonian brittle faults (Kirkland et al., 2005, 2006; Corfu et al., 2006). Second, K-Ar analyses of brittle fault gouge of the Kvenklubben fault in the Repparfjord-Komagfjord tectonic window yielded Carboniferous-early Permian ages and a subsidiary Early Cretaceous age (Torgersen et al., 2014). Third, recent $\mathrm{K}$-Ar faulting ages obtained for potential segments and splays of the LVF and TKFZ and associated faults indicate that normal faulting in NW Finnmark took place mostly in the Carboniferous and halted in mid-Permian times with only minor Mesozoic reactivation (Koehl et al., 2018b). By comparison, K-Ar ages for the VestfjordenVanna Fault Complex and related brittle normal faults in adjacent areas of Western Troms and Lofoten-Vesterålen yielded dominantly Late Devonian-early Carboniferous ages (Davids et al., 2013). Fourth, ${ }^{40} \mathrm{Ar}-{ }^{39} \mathrm{Ar}$ dating of dolerite dykes that intruded along WNW-ESE-striking brittle faults onshore Magerøya yielded Visean ages (early Carboniferous; Lippard \& Prestvik, 1997). Dolerite dykes trending $\mathrm{N}-\mathrm{S}$ to NE-SW are also present in the eastern part of the Varanger Peninsula (Guise \& Roberts, 
2002; Nasuti et al., 2015a) and on the Kola Peninsula in Russia (Roberts \& Onstott, 1995), where ${ }^{40} \mathrm{Ar}-{ }^{39} \mathrm{Ar}$ dating yielded Late Devonian ages. Fifth, ${ }^{40} \mathrm{Ar}-{ }^{39} \mathrm{Ar}$ dating of low-angle extensional shear zones in Vesterålen yielded Early Devonian ages (Steltenpohl et al., 2011).

\section{Methods and databases}

\section{Structural field study}

Brittle faults were mapped and characterised at outcrop scale with the main purpose to collect orientation data for brittle faults (Fig. 3) and host-rock ductile fabrics, unravel fault geometries, and study kinematic indicators in order to infer displacement magnitudes along brittle faults in NW Finnmark. In addition, the research team gathered information about the timing relationships between different fault sets where available. Structural data are plotted in lower-hemisphere equal-area stereonets as poles or great circles of planar fabrics, and as slip-linears of striated faults (Goldstein \& Marshak, 1988).

\section{Satellite images and Digital Elevation Model (DEM) data}

Digital 2D and 3D satellite imaging was used to infer the presence of brittle faults in the study area using surface intersections and tectonically controlled topographic lineaments. The interpretation of brittle faults and fractures on this dataset is based on the assumption that most of the observed lineaments in Norway are directly linked to the tectonic history and structural regime that affected northwestern Finnmark and northeastern Troms. Previous regional interpretations of similar datasets seem to confirm this assumption (Gabrielsen et al., 2002). The present satellite-image dataset is taken from www.norgei3d.no. Brittle faults interpreted on satellite images were compared to previously published bedrock maps (Roberts, 1973, 1987, 1998; Gautier et al.,

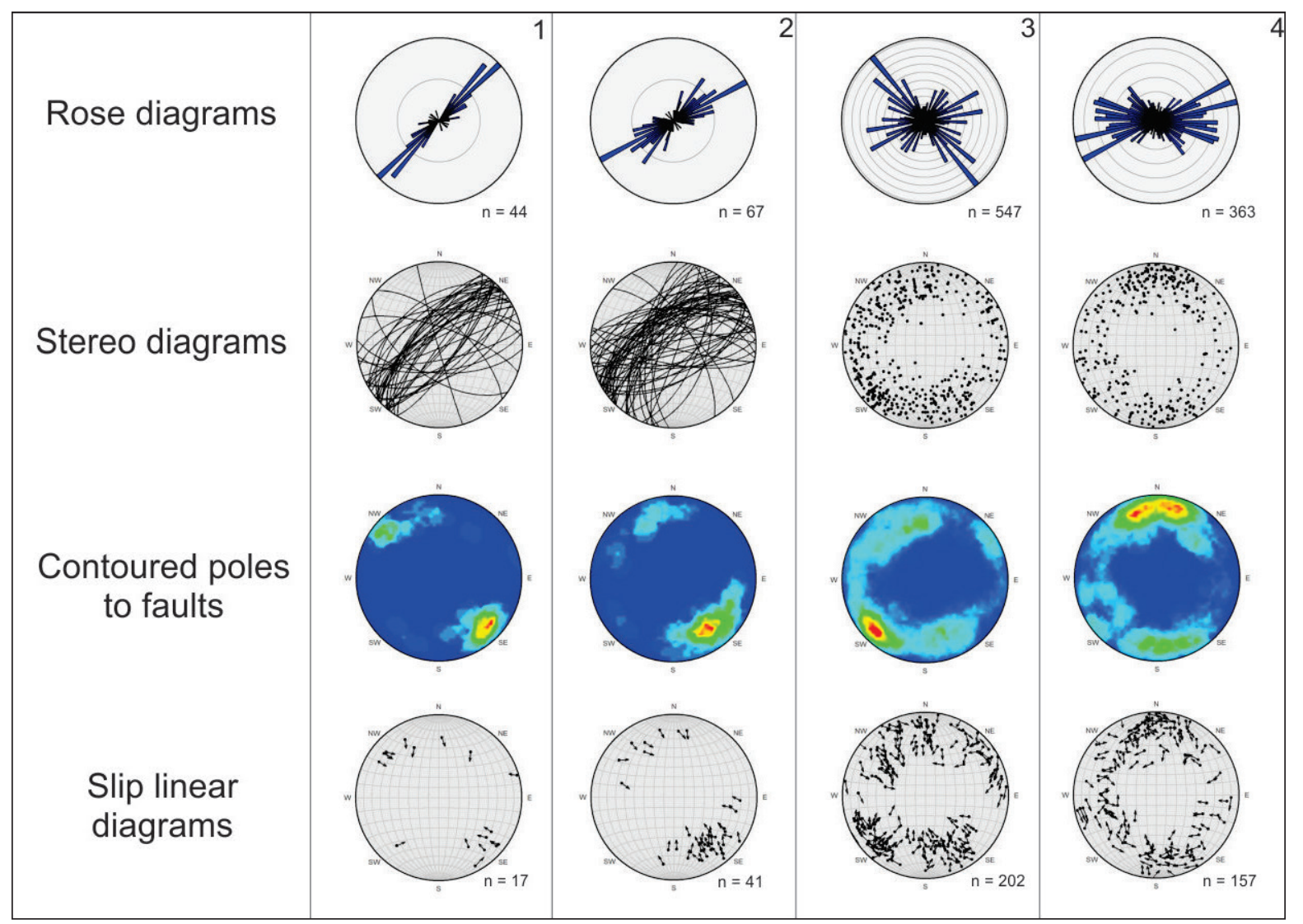

Figure 3. Brittle fault data from structural fieldwork, including from top to bottom: rose diagrams of measured fault strikes (grey circles represent an increment of four measurements), lower hemisphere Schmid stereonets showing fracture strike and dip as great circles (column $1 \& 2$ ) and poles to fault surfaces (columns $3 \& 4$ ), Schmidt stereonets showing fracture strike and dip as contoured poles (red indicates high fracture density and blue low fracture density), and slip-linear plots of slickenside lineations. Slip-linear is defined as the pole to the fault surface decorated by a line/arrow parallel with the direction of slip of the hanging wall (movement plane defined by the pole to the fault and the dip striae; Goldstein \& Marshak, 1988). Note the change of dominant fault trend from southwestern areas in Sørkjosen (column 1) and Altafjorden (column 2) dominated by ENE-WSW-and NNE-SSW-striking faults, compared with northeastern areas on the Porsanger Peninsula (column 3) and Mageroya (column 4), which display a dominance of WNW-ESEand ENE-WSW-striking faults. 
1987; Zwaan et al., 1987; Robins, 1990a, b) and correlated with results from fieldwork and interpretation of aeromagnetic, topography and bathymetry data.

\section{Bathymetry and topography data}

Nearshore bathymetry data were provided by the sea mapping division of the Norwegian Mapping Authority (Kartverket, Sjødivisjonen), and cover the strandflat area off the coasts and parts of the fjord network of NW Finnmark and northeastern Troms (Fig. 4). However, areas closer to the shore and narrow fjords are not covered by the bathymetry dataset. The bathymetry data were acquired with a maximum resolution of $25 \times 25 \mathrm{~m}$ horizontally and $10 \mathrm{~m}$ vertically. Onshore topography data have a lateral resolution of $10 \times 10 \mathrm{~m}$ and a vertical resolution of $10 \mathrm{~m}$. The interpretation of bathymetry data aims at studying the trend, length and dip of submarine escarpments, troughs and ridges observed on the strandflat, where glacial sediments are supposedly absent. Similar studies of the submarine relief on the strandflat off the coasts of western Troms enabled Indrevær \& Bergh (2014) to identify Precambrian basement ductile fabrics, Caledonian thrust nappes and post-Caledonian brittle faults. In NW Finnmark, however, glacial sediments cover parts of the strandflat and fjords, and abundant glacial features such as ploughmarks, glacial troughs (e.g., Djuprenna trough), moraines (Ottesen et al., 2008; Barbolla et al., in prep.) and large glacial sediment fans (Vorren et al., 1986; Fig. 4) complicate the interpretation of brittle faults because of the tendency of glacial drainage systems to use preexisting troughs and zones of weakness in the bedrock (e.g., brittle faults, bedrock ductile fabrics). We therefore apply bathymetry data to correlate lineaments on the strandflat in NW Finnmark with onshore geology and lineaments mapped in the field, on satellite photographs, topography data and from previous studies (Gabrielsen, 1984; Vorren et al., 1986; Lippard \& Roberts, 1987; Townsend, 1987a; Roberts et al., 2011). Glacial features are not described and ductile fabrics are discussed only when they are potentially controlling the formation of brittle faults.

\section{Aeromagnetic anomaly data}

We applied supplementary onshore-nearshore aeromagnetic data from the Geological Survey of Norway (Nasuti et al., 2015b) including aeromagnetic data (Fig. 5A) and a tilt-derivative function (Fig. 5B) to identify abrupt changes in the bedrock that may localise brittle

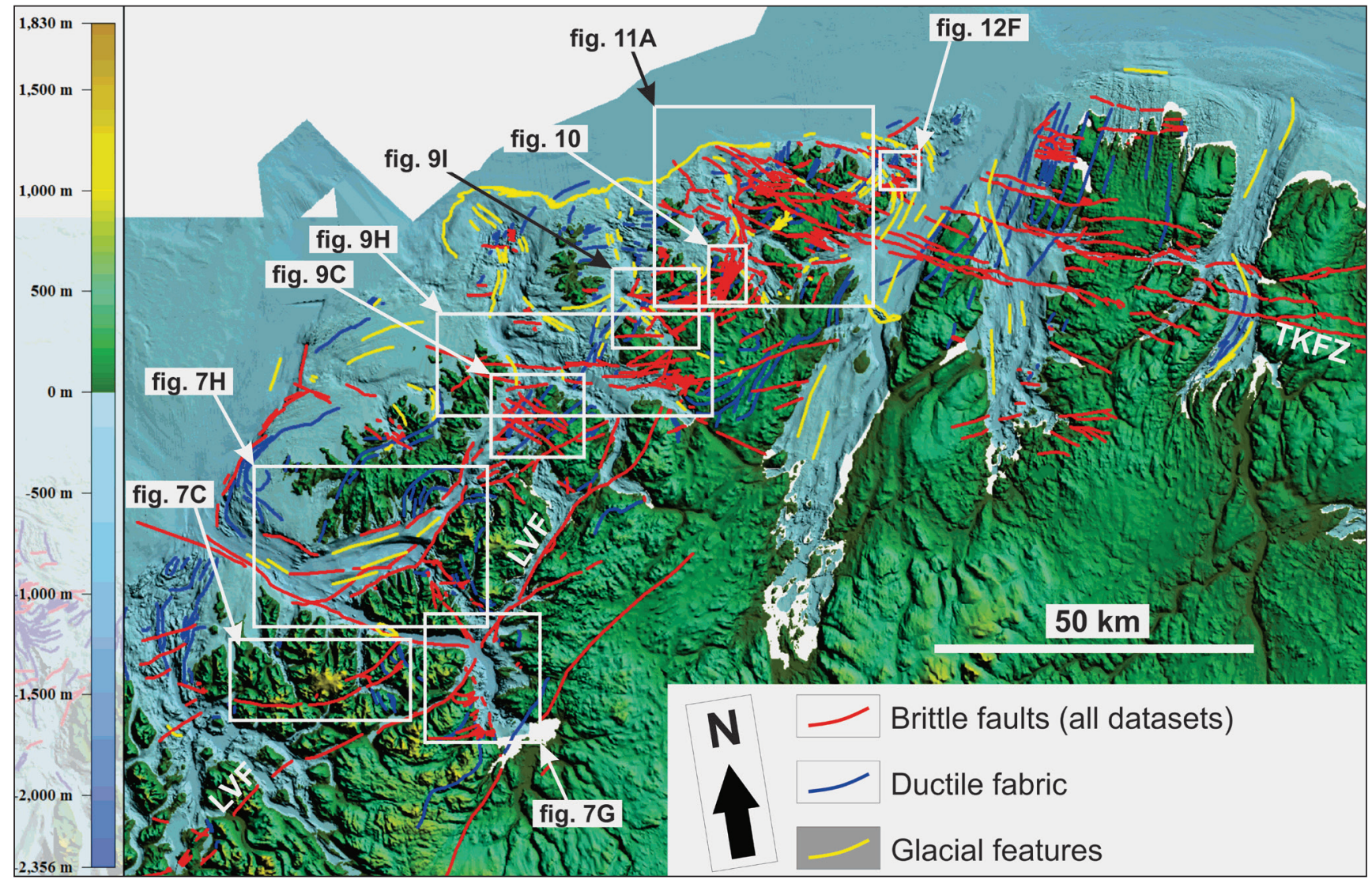

Figure 4. High-resolution topography and bathymetry data in NW Finnmark showing interpreted brittle faults (red lines) based on satellite images, structural field data, bathymetry, topography and aeromagnetic data (Nasuti et al., 2015a). Bedrock ductile fabrics (blue) dominantly trend NE-SW to NNE-SSW. The map also shows abundant glacial striations (yellow lines) and delineates three glacial sediment fans along the northern edge of the strandflat. The colour scale bar on the left-hand side denotes depth above (yellow-green) and below (blue) sea level. 


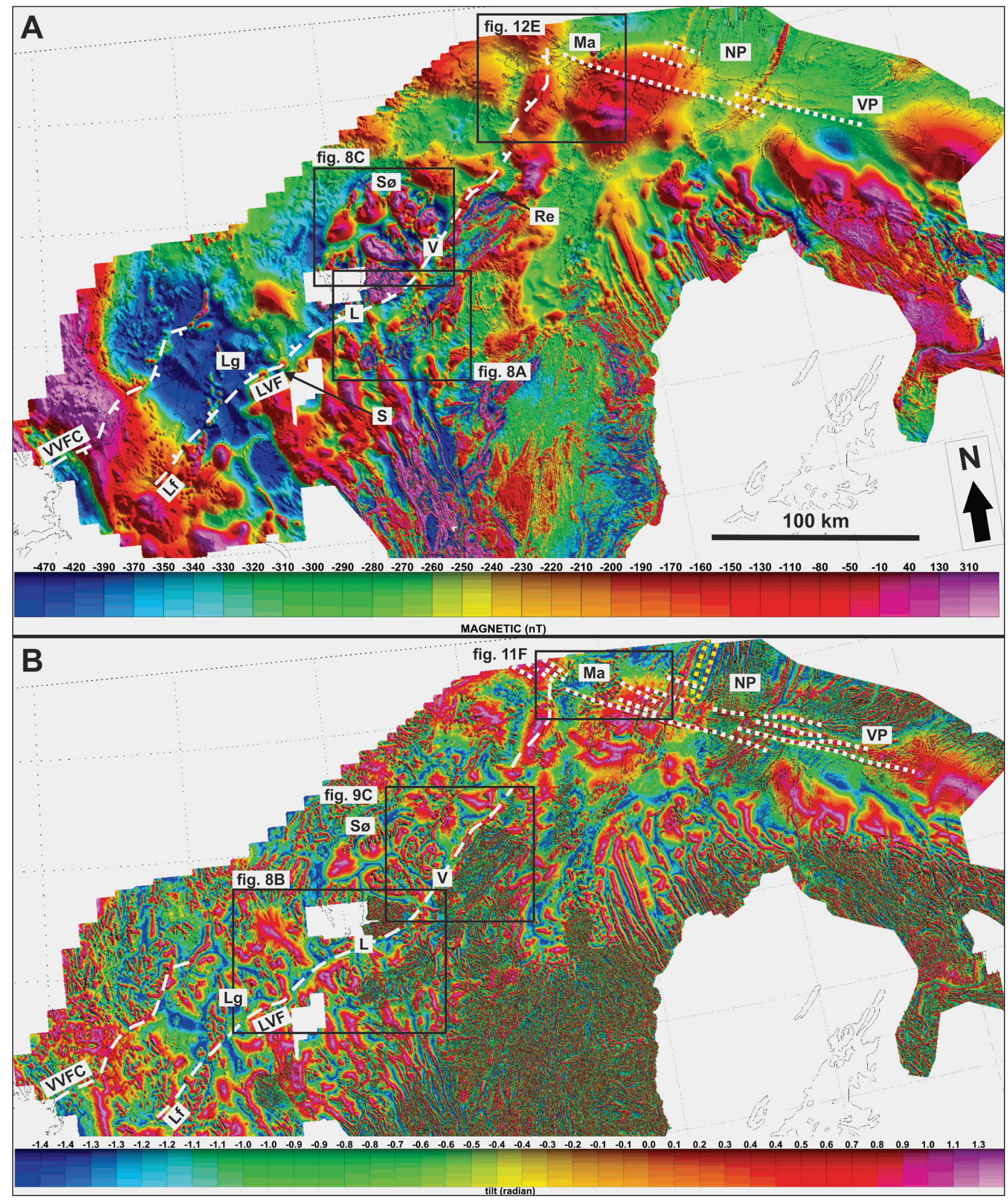

Figure 5. Aeromagnetic data from the Geological Survey of Norway (Nasuti et al., 2015a, b). (A) Aeromagnetic anomaly map of Troms and Finnmark showing well-defined large-scale, 10-80 km-wide, NW-SE- to NNW-SSE-trending, successive positive and negative anomalies depicting Precambrian granite and gneiss belts, and more diffuse NE-SW-trending Caledonian (nappe) fabrics. The data also highlight linear, elongated, WNW-ESE-trending, positive anomalies (dotted white lines) on Magerøya (Ma) and on the Varanger Peninsula (VP). Major margin-parallel fault complexes (LVF and Vestfjorden-Vanna Fault Complex) are shown in dashed white lines. Note the tentative continuation of the LVF southwestwards of Lyngenfjorden (Lg) as the Laksvatn fault (Lf). (B) Tilt-derivative of aeromagnetic data in Troms and Finnmark showing numerous WNW-ESE-trending, high positive aeromagnetic anomalies interpreted as dolerite dykes extending from the Varanger Peninsula (VP) to Magerøya (Ma; Nasuti et al., 2015a, b). The dotted yellow curve in the north delineates a positive aeromagnetic anomaly that correlates with a major syncline structure partly cropping out on the Nordkinn Peninsula (NP; Roberts \& Siedlecka, 2012; Roberts \& Williams, 2013). White-shaded areas indicate a lack of data coverage. 


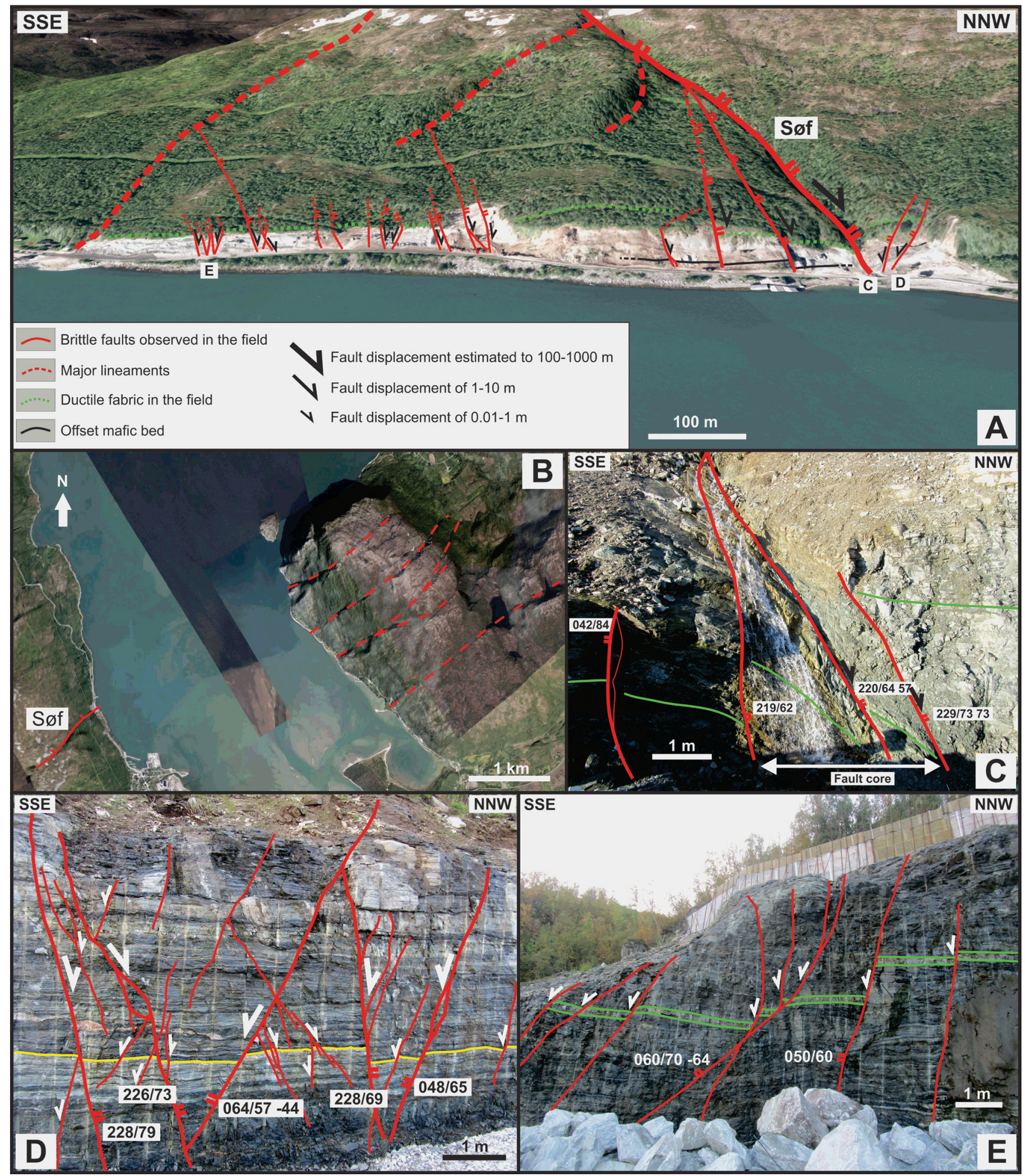

faults, and to delineate possible magmatic intrusions (e.g., dolerite dykes) emplaced along brittle faults (Nasuti et al., 2015a). Importantly, significantly different rocks may yield very similar magnetic responses. A crucial example in northern Finnmark is that of the similar, narrow, positive aeromagnetic anomalies produced both by dolerite dykes emplaced along brittle faults (see dotted white lines in Fig. 5A, B; Roberts et al., 1991; Nasuti et al., 2015a) and by folded magnetite-rich metasandstone beds (see dotted yellow lines in Fig. 5B; Roberts \& Siedlecka, 2012; Roberts \& Williams, 2013). We will therefore use aeromagnetic data as a confirmation tool to infer the presence of potential brittle faults in NW Finnmark. The aeromagnetic data are compiled from surveys acquired with different flight-line spacing and flying altitude: 500 and 200 m.a.s.l., respectively, in western Finnmark, 1000 and $200 \mathrm{~m}$ in northern Troms, and 200 and $60 \mathrm{~m}$ in eastern and southern Finnmark (Nasuti et al., 2015a, b). 


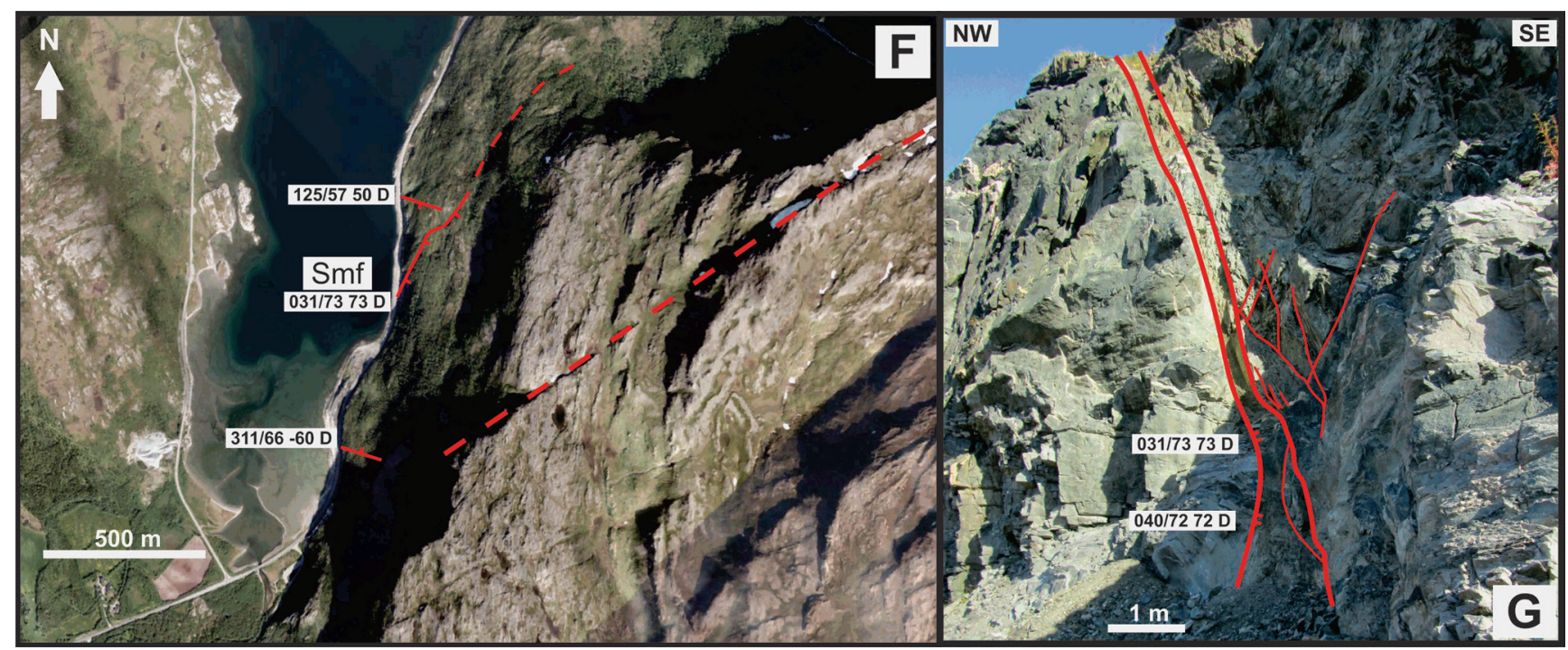

Figure 6. (page 10 and 11) (A) Outline of the Sørkjosen fault (Søf) and related subparallel minor faults (red lines), and of E-W-to WNW-ESE-trending lineaments curving into the Sørkjosen fault (dashed red lines) viewed in 3D satellite image (see Fig. 1 and Fig. 2 for location). Note the southward decrease in the amount of throw along brittle faults in the footwall of the Sørkjosen fault (e.g., offset mafic bed). The dominant Caledonian bedrock fabric is subhorizontal. (B) Map-view satellite image of the Sørkjosen fault (Søf; red line) with associated fault strike, dip, and slickenside lineations (white boxes; D down), and of NE-SW-trending lineaments on the northeastern side of the fjord (dashed red lines). Location is shown in Fig. 2. (C) Outcrop photograph of the Sørkjosen fault core with bedrock fabric (green lines) curving clockwise into the fault core. Location shown in (A). (D) Outcrop photograph in the hanging wall of the Sørkjosen fault showing antithetic, SSE-dipping, planar and listric brittle faults with a few tens of cm of normal displacement (see offset felsic unit in green lines). Location is shown in (A). (E) Outcrop photograph of a swarm of ENE-WSW- to NE-SW-trending, oppositely dipping, planar faults arranged in horst-graben structures and showing minor, cm-scale normal offsets of gneiss bands (yellow lines). Location shown in (A). (F) Satellite image of the Straumfjordbotn fault (Smf; red line) and its possible extension to the northeast (dashed red lines). The photo also shows a large $N E-S W$-trending lineament east of the fjord that may represent a major brittle fault. Location of the Straumfjordbotn fault shown in Fig. 2. (G) Outcrop photograph of the Straumfjordbotn fault with associated structural measurements.

\section{Results}

Three major fault trends were identified among which margin-parallel (1) ENE-WSW- and (2) NNE-SSW-striking faults (e.g., LVF) dominate the southwestern part of Finnmark from Sørkjosen to Revsbotn (Figs. 1, 2 \& 3), while margin-oblique (3) WNW-ESE-striking faults (e.g., TKFZ) are more abundant in the northeast, on the Porsanger Peninsula and Magerøya (Figs. 2 \& 3). We describe onshorenearshore fault geometries and kinematic characters and, where possible, relative timing constraints of brittle faults belonging to these three major trends (Figs. 2 \& 3) and link fault traces using bathymetry data from adjacent fjords (Fig. 4) and aeromagnetic data (Fig. 5).

\section{ENE-WSW- and NNE-SSW-striking faults}

Faults in Sørkjosen-Langfjorden-Altafjorden

In Sørkjosen, a major NNW-dipping fault, the Sørkjosen fault, and associated minor faults are exposed in a c. one $\mathrm{km}$-long, NNW-SSE-trending road-cut in granodioritic gneisses of the Precambrian basement with a subhorizontal foliation (Fig. 6A; Zwaan et al., 1987; Lindahl et al., 2005). On satellite images, this fault coincides with a major ENE-WSW-trending lineament that quickly dies out to the west (Fig. 2) but can be traced northeastwards across the fjord as a series of pronounced, sub-parallel, NE-SW- to NNE-SSW-trending lineaments (Fig. 6B). E-W- to WNW-ESE-trending lineaments, potentially representing older brittle faults, appear to curve into the Sørkjosen fault (see dashed red lines in Fig. 6A). At outcrop scale, the Sørkjosen fault core comprises metrethick lenses of cataclastic fault-rocks crosscut by a dense network of microscopic-scale faults and veins partly filled up with calcite cement (Fig. 6C). Slickenside lineations along clay-rich fault surfaces in the fault-core indicate normal dip-slip to oblique-slip, down-NNW movement, which is also supported by a gradual clockwise rotation of foliation surfaces in granodioritic gneiss toward the fault core (Fig. 6C). The amount of normal offset along the Sørkjosen fault is difficult to resolve because of the lack of correlative geological markers across the fault. However, the absence of a c. $30 \mathrm{~cm}$-thick amphibolite unit in the hanging wall suggests a vertical throw of a minimum of $c$. 10 metres (Fig. 6A), while a maximum estimate of $500 \mathrm{~m}$ is based on the thickness of the granodioritic gneiss unit (Zwaan et al., 1987).

Furthermore, in the hanging wall of the Søkjosen fault, we observed minor antithetic, SSE-dipping brittle faults characterised by vertically splaying listric geometries arranged in half-graben structures (Fig. 6D). Normal 


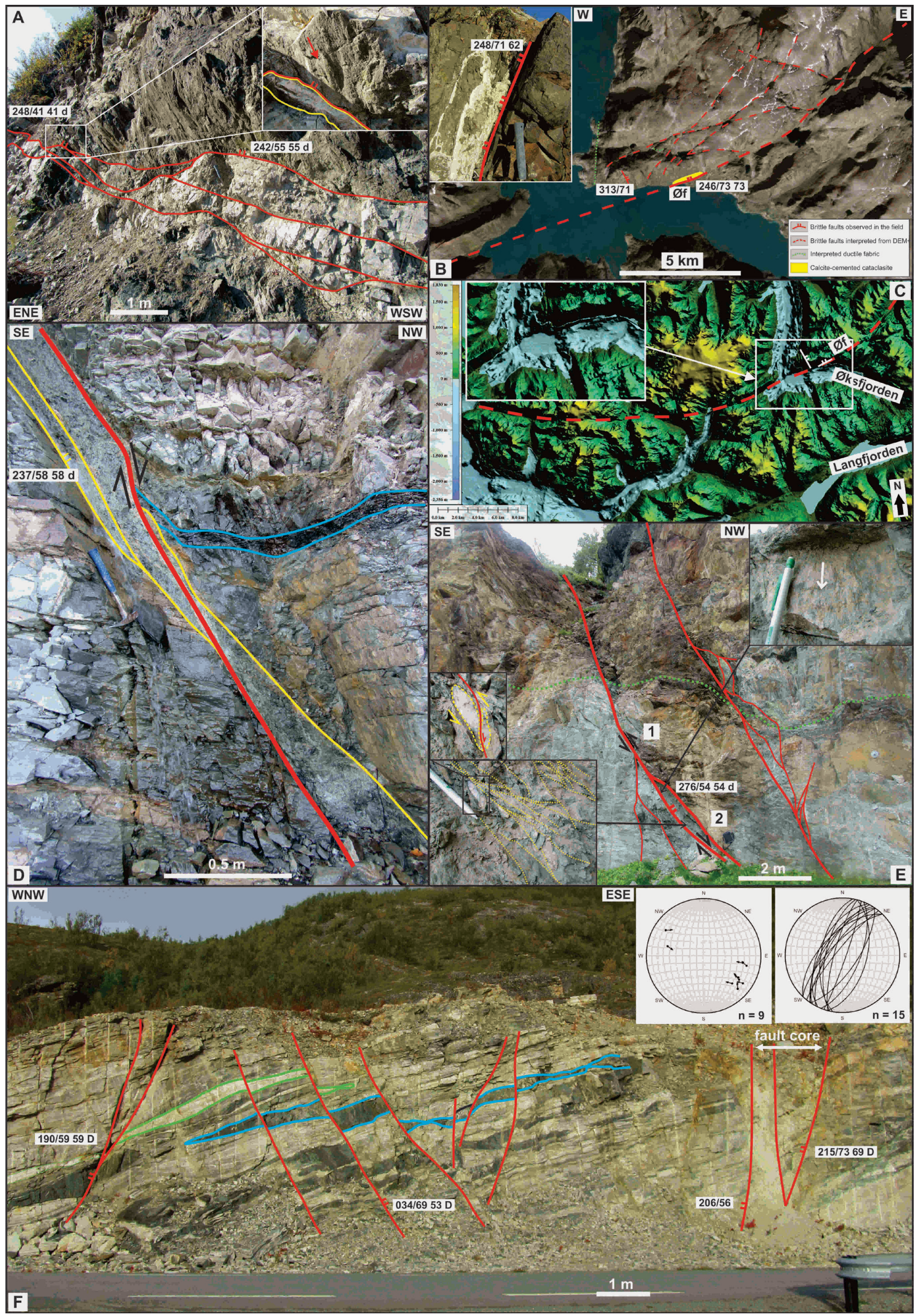




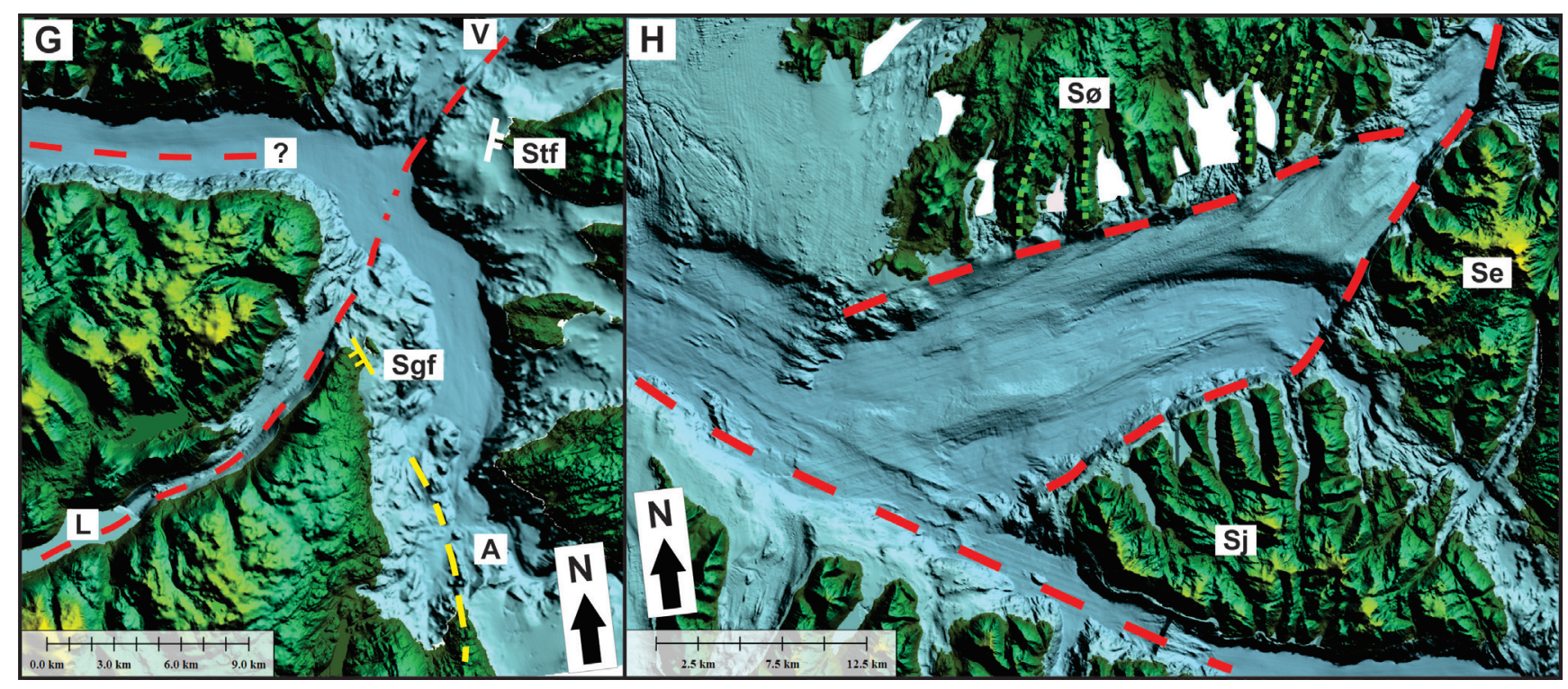

Figure 7. (A) Outcrop photograph of NNW-dipping brittle faults along the northern shore of Langfjorden (red lines; see Fig. 2 for location), showing calcite-filled cataclastic fault-core (upper right frame) and slickengrooves (red arrow) indicating normal dip-slip movement. Location is shown in Fig. 2. (B) Satellite image showing the Øksfjorden fault (Øf) and ENE-WSW- and NNE-SSW-trending lineaments (faults) within rocks of the Seiland Igneous Province. The upper-left inset shows the Øksfjorden fault core, which incorporates calcite-cemented cataclasite. See location in Fig. 2. (C) Bathymetry-topography in Øksfjorden showing submarine escarpments related to the outcrop occurrence of the $\emptyset k s f j o r d e n$ fault (Øf; white line) and its possible westward extension, curving into an E-W to WNW-ESE trend (dashed red line). Elevation colour scheme shown here is common to all bathymetry-topography figures. See Fig. 4 for location. (D) Outcrop photograph of the Altafjorden fault 1 and associated structural measurements with slickensides indicating down-NW normal dip-slip movement. The fault-core (yellow lines) appears downthrown to the NNW along a cm-thick, clay-rich slip surface (red line). Location shown in Fig. 2. (E) Outcrop photograph of the Talvik fault. The upper-right inset shows the main fault surface, which displays slickengrooves (white arrow) indicating normal dip-slip movement. The lower- and middle-left insets, respectively, show relict ductile shear-band fabric (dotted yellow) and quartz sigma-clasts (dashed yellow) in the fault core that indicate top-SE thrusting. These ductile fabrics are cross-cut by subsequent brittle normal dip-slip faults (see red line in middle-left box). Location is shown in Fig. 2. (F) NNE-SSWtrending horst-graben structures in foliated quartzofeldspathic Kalak Nappe Complex gneisses on the eastern shore of Altafjorden. Structural measurements of slickenside lineations and offsets of boudinaged mafic (blue lines) and felsic (green lines) units indicate normal dip-slip sense of shear for graben-bounding faults. Location is shown in Fig. 2. (G) Bathymetry data at the intersection of Altafjorden (A), Langfjorden ( $L)$ and Vargsundet $(V)$ showing submarine escarpments (dashed red lines) linked to the Langfjorden and Vargsundet segments of the LVF. Thick glacial deposits partly cover the trace of the LVF in Altafjorden. The field location of the Storekorsnes fault is showed in white. Dashed yellow lines mark NNW-SSE-trending submarine escarpments trending parallel to the bedrock fabric along the western shore of Altafjorden (Roberts, 1973) and aligning with the Storhaugen fault (Sgf; yellow line). Location in Fig. 4. (H) Topographic depression ascribed to the Sørøy sub-basin between the islands of Sørøya (Sø), Stjernøya (Sj) and Seiland (Se). The sub-basin is bounded by ENE-WSW- and NNE-SSW-trending, zigzag-shaped escarpments southeast- and northwards, and by a prominent WNWESE-trending lineament in the southwest. Areas coloured in white are gaps in data coverage. Location shown in Fig. 4. offsets of sub-horizontal granodioritic gneiss bands show that displacement along these faults is in the order of a few decimetres. In the footwall, we observed a succession of dominantly NNW- to NW-dipping brittle faults showing a variable amount of down-NW normal offset. Near the Sørkjosen fault core, a NNW-dipping fault displays c. $10-15 \mathrm{~m}$ vertical offset of the c. $30 \mathrm{~cm}$-thick amphibolite unit that is missing in the hanging wall of the Sørkjosen fault (Fig. 6A). Southwards, minor subparallel faults become planar in cross-section and in places form metre-wide horst-graben structures, showing decreasing amounts of vertical offset of geological markers from a few metres down to a few centimetres (Fig. 6A, E).

In Straumfjordbotn, c. $20 \mathrm{~km}$ east of Sørkjosen (Fig. 2), a large ESE- to SE-dipping fault, the Straumfjordbotn fault, crops out and correlates with a minor NNESSW-trending lineament on satellite images that strikes subparallel to a nearby, major, NE-SW-trending escarpment (Fig. 6F). The Straumfjordbotn fault exhibits slickengrooves that indicate down-ESE/SE normal movement (Fig. 6G) of uncertain magnitude due to a lack of convincing correlative markers on both sides of the fault. The fault core is about $0.5 \mathrm{~m}$ wide and shares similar characteristics with that of the Sørkjosen fault. For example, both fault cores are composed of clay-rich cataclastic fault-rocks with abundant calcite cement. Considering the proximity, fault-core similarities, and opposite dip of the Straumfjordbotn and Sørkjosen faults, we interpret the Straumfjordbotn fault as a subsidiary antithetic splay fault of the Sørkjosen fault.

Langfjorden is a $50 \mathrm{~km}$-long, narrow, linear fjord in western Finnmark trending ENE-WSW (Figs. 1 \& 2). Slickensided brittle faults with similar strike, NNW to NW dips, and normal dip-slip to normal-dextral oblique-slip movement indicators (Fig. 7A) occur in gabbroic rocks of the Seiland Igneous Province on the northern shore of the fjord (Fig. 7A). The faults show centimetre-thick lenses of calcite-cemented cataclastic 
fault rock and locally incorporate decimetre- to metrescale lenses of granitic augen gneiss (Fig. 7A) that typically dominates Caledonian lithologies on the southern shore of Langfjorden (Roberts, 1973). We consider these faults to represent synthetic splay-faults of the LVF, which is believed to be partly eroded and buried by glacial sediments within the fjord (Zwaan \& Roberts, 1978; Lippard \& Roberts, 1987; Roberts \& Lippard, 2005), and interpret the lenses of granitic gneiss as fault lenses downfaulted to the north-northwest due to extensional movement along the LVF and associated splay-faults.

In Øksfjorden, north of Langfjorden, NNE-SSW- and ENE-WSW-trending lineaments are visible on satellite images, some of which align and correlate with highangle, NNW- to WNW-dipping brittle faults, e.g., the Øksfjorden fault, which strikes oblique to the gently west-dipping Caledonian host-rock fabric (Fig. 7B). In map-view, the Øksfjorden fault shows an arcuate geometry comparable to that of the LVF, striking ENEWSW in Øksfjorden and curving into an NE-SW strike to the northeast (Fig. 7B). At outcrop scale, slickensided surfaces along the Øksfjorden fault suggest normal dip-slip extensional movement, and the associated dominant fault-rocks found along the fault include fault gouge and calcite-filled cataclasite developed from the amphibolitic host-rock (Fig. 7B). The Øksfjorden fault coincides with a smooth, arcuate lineament in the nearby fjord that may represent the western prolongation of the fault (Fig. 7C), truncating the southeastern extension of a presumably older NE-dipping brittle fault on the northern shore of Øksfjorden (Fig. 7B). Although partly truncated by a circular trough filled with glacial sediments, the Øksfjorden fault may continue onshore to the west where it gradually curves into a WNWESE trend, parallel to a similarly trending topographic depression (Figs. 2, 4 \& 7C). In this area, the Øksfjorden fault shows a c. 200-250 m right-lateral offset of a large lens of garnet-bearing gneiss within the Seiland Igneous Province (Roberts, 1973), suggesting that the Øksfjorden fault accommodated dextral strike-slip to dextral-normal oblique-slip movement. The lateral variations of inferred kinematics along the Øksfjorden fault may be ascribed to the arcuate map-view geometry of the fault (Fig. 7C), which likely accommodated dip-slip normal movement near its centre in Øksfjorden, and normal obliqueslip displacement with a gradual increase in lateral displacement towards the fault tips. Despite the change of host-rock, the strike, arcuate geometry, similarity of fault-rock composition and consistent extensional (dipslip to oblique-slip) kinematic indicators suggest that the Øksfjorden fault is part of the same fault system as the Langfjorden, Sørkjosen and Straumfjordbotn faults, i.e., the LVF.

New road-cuts along the western shore of Altafjorden unveiled multiple ENE-WSW- to NE-SW-striking, dominantly NW-dipping brittle faults, e.g., Altafjorden fault 1 (Fig. 7D), arranged in half-graben structures (Figs.
$2 \& 7 \mathrm{D}, \mathrm{E})$. These faults offset foliated Caledonian metaarkose of the Kalak Nappe Complex and psammitic schists and meta-arkose of the Alta-Kvænangen tectonic window. Most major fault surfaces display slickengrooves indicating normal dip-slip to normal-dextral obliqueslip sense of shear (Fig. 7D, E). Normal motions along brittle faults in this area are also supported by apparent upwards bending (drag-folding) of the flat-lying hostrock foliation into high-angle brittle faults (Fig. 7D). Fault cores include multiple slip-surfaces displaying faulting-related clay minerals (gouge) and cataclastic lenses of host-rock. Other NW- to north-dipping brittle faults such as the Talvik fault (see Figs. 2 \& 7E) show evidence of both normal brittle and ductile reverse motion, indicating that brittle faults in Altafjorden may have experienced several movement episodes. Ductile kinematic indicators along the Talvik fault include sheared quartz $\sigma$-clasts and a distributed viscous fabric within the fault core (Fig. 7E) similar to that of the Kvenklubben fault in Vargsundet (Torgersen \& Viola, 2014; Fig. 2), indicating top-south/southeast thrusting. Cross-cutting relationships show that ductile fabrics are consistently truncated by brittle fabrics (Fig. 7E), thus indicating that ductile thrusting occurred first and was later overprinted by brittle normal faulting. Since the inferred top-south transport direction matches those proposed by Townsend (1987b) and Marti (2013) within the Kalak Nappe Complex south of Langfjorden, the contractional kinematic indicators likely reflect a phase of Caledonian ductile thrusting. We propose that brittle-ductile faults observed on the western shore of Altafjorden, e.g., the Talvik fault (Fig. 7E), formed as Caledonian ductile thrusts that accommodated top-SE movement and were later reactivated as normal faults during post-Caledonian extension.

On the eastern shore of Altafjorden (Figs. $1 \& 2$ ), the dominant fault trend switches to a NNE-SSW trend (Fig. 7F) that is oblique to the ENE-WSW to NE-SW trend dominating in Langfjorden, Øksfjorden and along the western shore of Altafjorden (see Fig. 7A-D). In this area, brittle faults commonly display metre-scale normal offsets of geological markers (e.g., shallowdipping mafic dykes; Fig. 7F) and ductile host-rock gneissic fabric, and define meso-scale horst and graben structures (Fig. 7F). Slickensided fault surfaces indicate normal dip-slip movement (e.g., Fig. 7F). Near the southwestern tip of Vargsundet, we observed a steep c. $5 \mathrm{~m}$-wide ESE-dipping (i.e., opposite to that of the LVF) fault, termed the Storekorsnes fault, characterised by a wide fault corridor and cataclastic fault-rock. This large fault crosscuts a $50 \mathrm{~cm}$-thick mafic dyke that was not observed in the hanging wall and this suggests that the fault accommodated movement $>10 \mathrm{~m}$. Because of the proximity of the Storekorsnes fault to the LVF in Vargsundet, and by analogy to the opposite dips of the Straumfjordbotn fault and adjacent Sørkjosen fault, we interpret the ESE-dipping Storekorsnes fault as an antithetic, minor splay-fault of the LVF. 
In Langfjorden, Altafjorden and Vargsundet (Fig. 1), the trace of the LVF correlates with steep ENEWSW- to NNE-SSW-trending submarine escarpments observed on bathymetry data (Fig. 7G). Notably, in the outermost part of Altafjorden, a wide trough filled with glacial sediments overlaps two escarpments trending ENE-WSW and NNE-SSW, respectively located at the northeastern end of Langfjorden and at the southwestern tip of Varsundet (Fig. 7G). These escarpments align and possibly connect in Altafjorden, mimicking the mapview geometry of the LVF inferred by previous works (Zwann \& Roberts, 1978; Lippard \& Roberts, 1987; Fig. 7G). A similar trough filled with glacial sediments defines a topographic depression in the sound between Sørøya and Stjernøya (Figs. 2 \& 7H). This trough, herein termed the Sørøy sub-basin, is bounded by two escarpments that trend ENE-WSW and NNE-SSW, parallel to the coastlines of the islands of Stjernøya and Seiland (Fig. 7H). These escarpments exemplify the zigzag geometry of the LVF in Altafjorden (Fig. 7G) and, thus, may correspond to brittle faults analogous to fault segments of the LVF.

Aeromagnetic data illustrate well the bedrock architecture of Troms and Finnmark reflecting the lithology of Precambrian rocks in the Alta-Kvænangen tectonic window (e.g., Henderson et al., 2015; Melezhik et al., 2015). Notably, we have observed broad zones (c. 10-80 $\mathrm{km}$ ) of NW-SE- to NNW-SSE-trending, alternating negative and positive anomalies (Fig. 5A), some of which coincide well with major lithological boundaries, e.g., in the West Troms Basement Complex in western Troms (Bergh et al., 2010). In addition, large pods of positive anomalies north of Langfjorden coincide with ultramafic rocks of the Seiland Igneous Province located within a c. $80 \mathrm{~km}$-wide, negative anomaly of felsic metamorphic assemblages (Roberts, 1973; Pastore et al., 2016). In Sørkjosen, Langfjorden, Altafjorden and Vargsundet, the trace of the LVF is outlined by multiple abrupt changes in aeromagnetic signals (Fig. 5A). Importantly, most prominent Precambrian NW-SE- to NNW-SSE-trending negative anomalies (e.g., below the islands of Ringvassøya and Vannøya (Fig. 1), and below the Seiland Igneous Province) abruptly narrow across the trace of the LVF to c. 10-30 km (Fig. 5A). Conversely, a $30 \mathrm{~km}$-wide, NWSE- to NNW-SSE-trending, positive anomaly north of Sørkjosen abruptly widens to c. $80 \mathrm{~km}$ across the LVF, southeast of Sørkjosen (Fig. 5A). Thus, we propose that NW-SE- to NNW-SSE-trending, alternating positive and negative aeromagnetic anomalies correspond to belts of macrofolded Precambrian basement, made up, respectively,of granite-gneiss (e.g., Ersfjord Granite; Bergh et al., 2010) and volcano-sedimentary rocks in metasupracrustal-greenstone belts (e.g., Ringvassøya Greenstone Belt; Bergh et al., 2010), which were downfaulted to the northwest by the LVF (Fig. 5A).

In outermost areas of Altafjorden, pronounced, narrow, NNW-SSE-trending positive anomalies coincide with folded, steeply west-dipping, Precambrian metavolcanic units in the Alta-Kvænangen tectonic window (Fig. 8A, B; Roberts, 1973; Zwaan \& Gautier, 1980; Bergh \& Torske, 1988). Northwards, this anomaly abruptly curves into an E-W to ENE-WSW trend and extends below the eastern shore of Altafjorden where it coincides with a north-dipping metavolcanic unit of the Altenes tectonic window (Fig. 8A, B; Roberts, 1973) of analogue composition and metamorphic grade (Jensen, 1996). We propose that metavolcanic units of the Alta-Kvænangen and Altenes tectonic windows link up in Altafjorden, defining a steeply NW-plunging antiformal fold structure (Fig. 8A, B). This fold is located just south of a bend of the LVF, where a NNW-dipping fault segment in Langfjorden parallels the NNW-dipping northern limb of this antiform, suggesting that changing Precambrian bedrock fabrics and structures may have controlled the geometry of the LVF and related brittle faults in Altafjorden (see Fig. 7D and later discussion).

Between Sørøya and Stjernøya (Fig. 1), aeromagnetic data depict large pods of high positive anomalies ascribed to rocks of the Seiland Igneous Province (Pastore et al., 2016). These pods are truncated by narrow, linear, E-Wand NE-SW-trending, negative anomalies, some of which coincide with the southeastern boundary of the Sørøy sub-basin (Fig. 8C). The zigzag pattern defined by these anomalies matches a similar pattern of NW-dipping subsurface escarpments in the fjord off the northern coasts of Stjernøya and Seiland, interpreted as brittle faults (Fig. 7H). Despite small mismatches in trend and location of anomalies and bathymetry scarps, we interpret the negative anomalies to reflect the extention of the Sørøy sub-basin boundary-faults at depth (Fig. 8C).

\section{Faults on the Porsanger Peninsula}

The Porsanger Peninsula consists of Caledonian psammites, schists and banded gneisses with a dominantly flat-lying foliation, deeply incised by a series of interconnected fjords and brittle faults trending NW-SE to WNW-ESE (see next section), ENE-WSW, and subsidiarilly NNE-SSW (Figs. 2, 3 \& 9A). The orientation of major fjords consistently matches the strike of the predominant local fault trend. For example, most faults and fractures in Eiterfjorden strike NNESSW, e.g., Selvika-Eiterfjorden fault (Figs. 2 \& 9A; Townsend, 1987a), though NNE-SSW are subsidiary on the Porsanger Peninsula, and this possibly suggests that glaciers preferentially eroded along existing brittle faults. ENE-WSW- to NNE-SSW-striking faults, like the Snøfjorden-Slatten fault (Townsend, 1987a), correlate with a suite of lineaments on satellite photographs (Fig. 9B). This major fault can be traced from Revsbotn to the southwestern tip of Ryggefjorden in the northeast (Figs. $1,2 \& 9 \mathrm{~A}$ ), where it displays listric and splaying attitudes, forming large rhomboid-shaped to anastomosing structures between overlapping faults in map view (Fig. 9C), and generating (half-)graben structures in crosssection. 


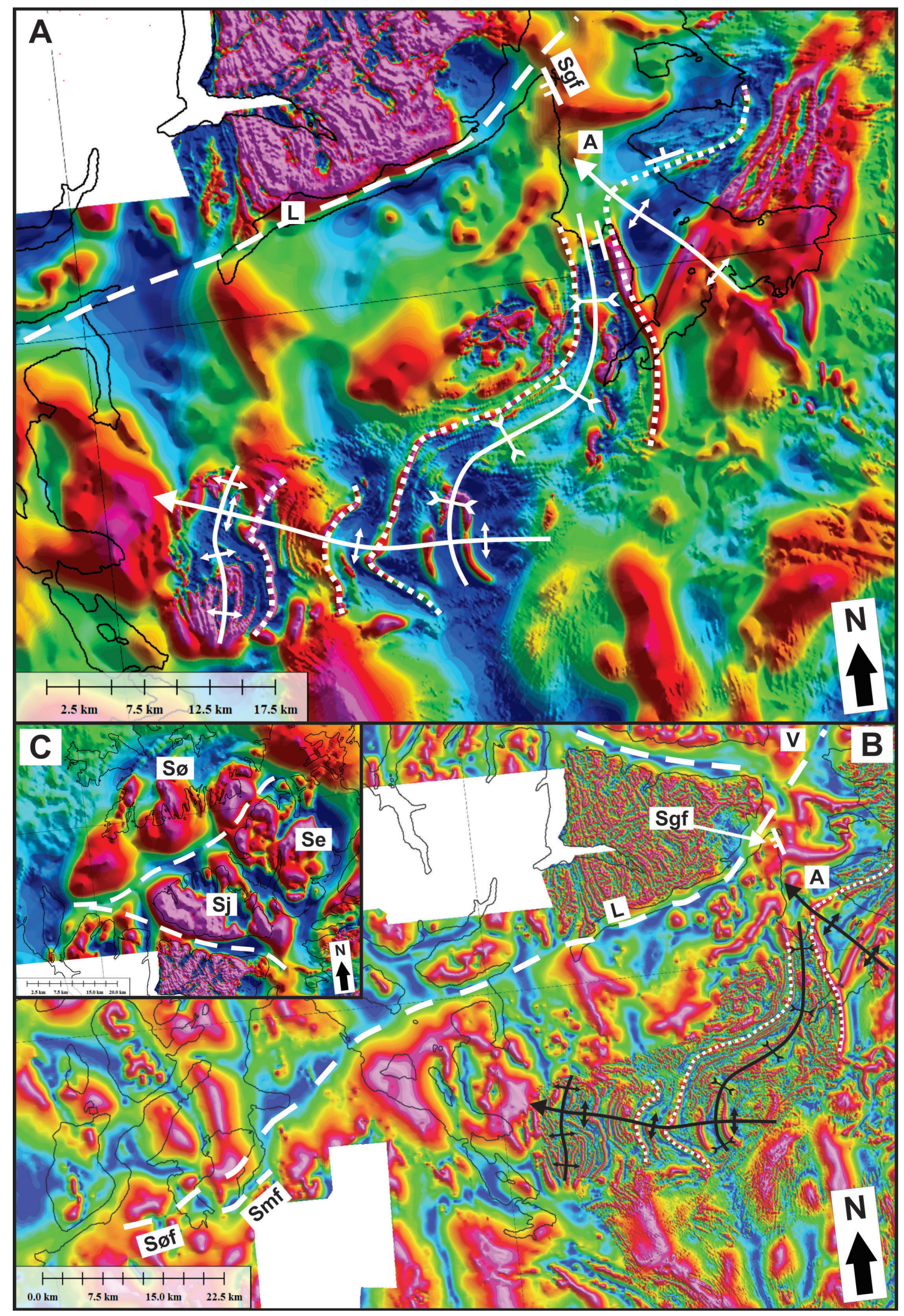


Figure 8. (A) Aeromagnetic data in Altafjorden (A) and south of Langfjorden $(L)$ showing positive aeromagnetic anomalies (dotted white lines) trending NNW-SSE in the west and ENE-WSW in the east, and coinciding with steeply dipping metavolcanic and sedimentary units of the Alta-Kvonangen and Altenes tectonic windows (dotted white lines). These anomalies define a steep NWSE-trending NW-plunging antiform fold structure in Altafjorden (white lines), the hinge zone of which coincides with a major bend of the LVF. The western limb of this antiform structure trends parallel to the Storhaugen fault (Sgf) and the northern limb parallels the LVF in Langfjorden (L). These anomalies extend westwards, south of Langfjorden, where they define another WNW-plunging antiform, the northern limb of which trends parallel to the LVF in Langfjorden. See Fig. 1 \& 2 for abbreviations, and Fig. 5A for location and data colour scheme. (B) Tilt-derivative showing an ENE-WSW-trending negative anomaly (dashed white line) following the trace of the LVF in Langfjorden ( $L$ ) and Sørkjosen (Søf). Aeromagnetic data also delineate possible refolded units (dotted white lines) in Proterozoic rocks of the Alta-Kvoenangen tectonic window, forming steep WNW to NW-plunging folds (black lines). See Fig. 1 \& 2 for abbreviations, and Fig. $5 B$ for location and data colour scheme. (C) Aeromagnetic data north of Langfjorden showing highly magnetic rocks of the Seiland Igneous Province cross-cut by zigzagging E-W- to NE-SW-trending, and WNW-ESE-trending negative anomalies, respectively, coinciding with the southeastern and southwestern boundary-faults of the Sørøy sub-basin.

Northeast of Vargsundet and Repparfjorden (Figs. 1 \& 2), a large NNE-SSW-trending escarpment appearing as a c. $10 \mathrm{~m}$-deep river gully in the field, correlates with multiple N-S to NE-SW-striking, dominantly WNWdipping brittle faults (Fig. 9D). Slickensided fault surfaces in the river gully indicate normal dip-slip to sinistralnormal oblique-slip sense of shear (Fig. 9D) and faults commonly incorporate $\mathrm{cm}$-thick lenses of quartzfilled cataclastic fault-rock. This major escarpment and similarly trending, outcrop-scale faults align with the LVF in Vargsundet and are therefore interpreted as the continuation of the LVF (Fig. 2), most likely representing minor, synthetic splay faults of the LVF (Fig. 9D). This is supported by a narrow, zigzagging, ENE-WSW- to NNESSW-trending, positive aeromagnetic anomaly stretching from the northeastern part of Vargsundet to the river gully north of Repparfjorden (Fig. 9E), where it parallels outcrop-scale brittle faults (Fig. 9D), and gradually dies out towards Revsbotn.

West of Kvaløya, bathymetry data show a network of steep, interconnected, NW-SE- to WNW-ESE-trending and E-W- to ENE-WSW-trending escarpments, in conjunction with pervasive, smooth, NE-SW-trending corrugations at the bottom of the fjord (Fig. 9F). These corrugations correspond in geometry, frequency and orientation with the strike of the main foliation fabric of bedrock gneisses onshore Kvaløya, which displays a consistent NE-SW trend and moderate to gentle northwestward dip (Roberts, 1973; Jansen et al., 2012). The presence of partly overlapping ENE-WSW-, and oblique E-W-striking brittle faults is inferred from the relatively steep character of ENE-WSW- to E-Wtrending escarpments and from a c. $400 \mathrm{~m}$-wide, leftlateral offset of a NW-SE-trending lineament in the fjord (Fig. 9F), which potentially indicates sinistral strike-slip movement along E-W- to ENE-WSW-striking brittle faults.

Slickensided ENE-WSW-striking fault surfaces on the Porsanger Peninsula mostly record normal dextral/ sinistral oblique-slip motion, whereas movements along subsidiary NNE-SSW-striking faults are dominantly dipslip normal (Fig. 3). Such fault characters are supported by rotation of ductile host-rock fabric across brittle faults. In outcrops, the fault-core of the SE-dipping SnøfjordenSlatten fault defines several metre-wide zones of shattered host-rock composed of clay-rich fault gouge and cataclasite lenses (Fig. 9G). Overall, the geometric and kinematic characters of ENE-WSW- and NNESSW-striking brittle faults on the Porsanger Peninsula suggest that these fault trends are genetically related to the LVF. More specifically, the Snøfjorden-Slatten fault (Fig. 9G) may represent the onshore continuation of the LVF on the Porsanger Peninsula or corresponds to an antithetic splay-fault related to the LVF. This is supported by the apparent alignment of the Snøfjorden-Slatten fault (Fig. 9E, G) with a major NE-SW- to NNE-SSWtrending escarpment northeast of Repparfjorden (Figs. 2 \& 9D).

Bathymetry data in Revsbotn (Fig. 1) show steep southdipping escarpments merging with major onshore lineaments of comparable E-W to ENE-WSW trend on the Porsanger Peninsula. Westwards, these submarine escarpments link up with E-W- to WNW-ESE-trending lineaments that correlate with brittle faults, some of which potentially offsetting the Kjøtvika fault from the Skarvdalen fault in Northeast Sørøya, e.g., the Akkarfjord fault (Fig. 9H; Roberts, 1971). Further, these escarpments trend oblique to NE-SW- to NNE-SSW-trending ridges correlating with ductile bedrock fabrics onshore Kvaløya (Fig. 9F, H) and to irregular glacial ploughmarks in Revsbotn (Fig. 9H). Thus, we interpret E-W- to ENEWSW-trending escarpments in Revsbotn as brittle fault segments of the Akkarfjord fault. These brittle faults strike oblique to the NNE-dipping Kokelv Fault, and the lack of WNW-ESE-trending lineaments in Revsbotn indicates that the Akkarfjord fault truncates the Kokelv Fault, which possibly terminates at the southeastern end of Revsbotn (Figs. 2 \& 9H). In addition, topographic data on the northeastern shore of Revsbotn and bathymetry data in Snøfjorden display steep NNE-SSW-trending escarpments (Fig. 9H, I) that overlap with a series of brittle faults cross-cutting the sub-horizontal Caledonian foliation at a high angle. We interpret these NNE-SSWtrending escarpments as the continuation of the LVF across Revsbotn (Fig. 9H).

A dense network of interconnected, steep, NNE-SSWand ENE-WSW-trending lineaments forming a c. 2 


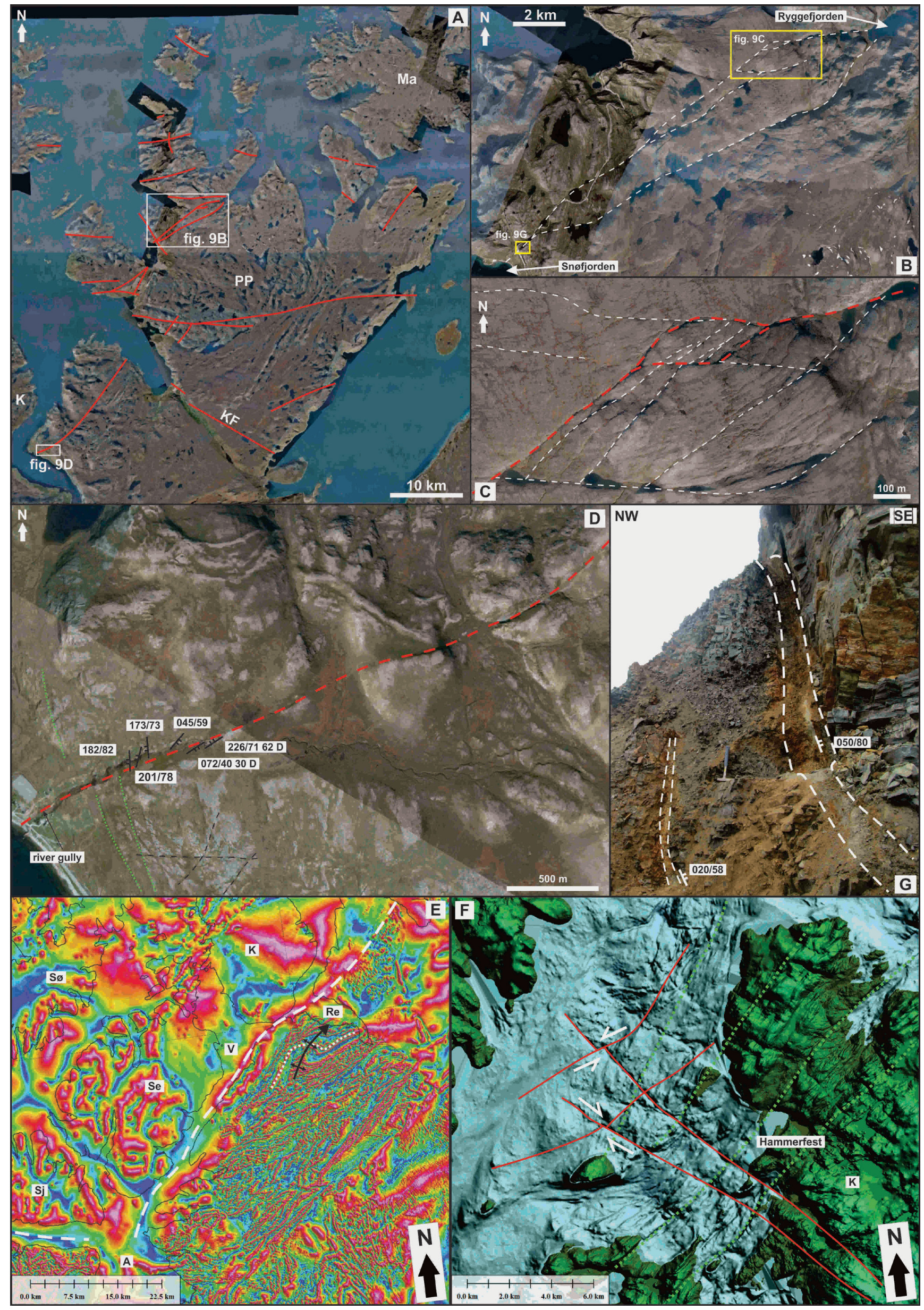




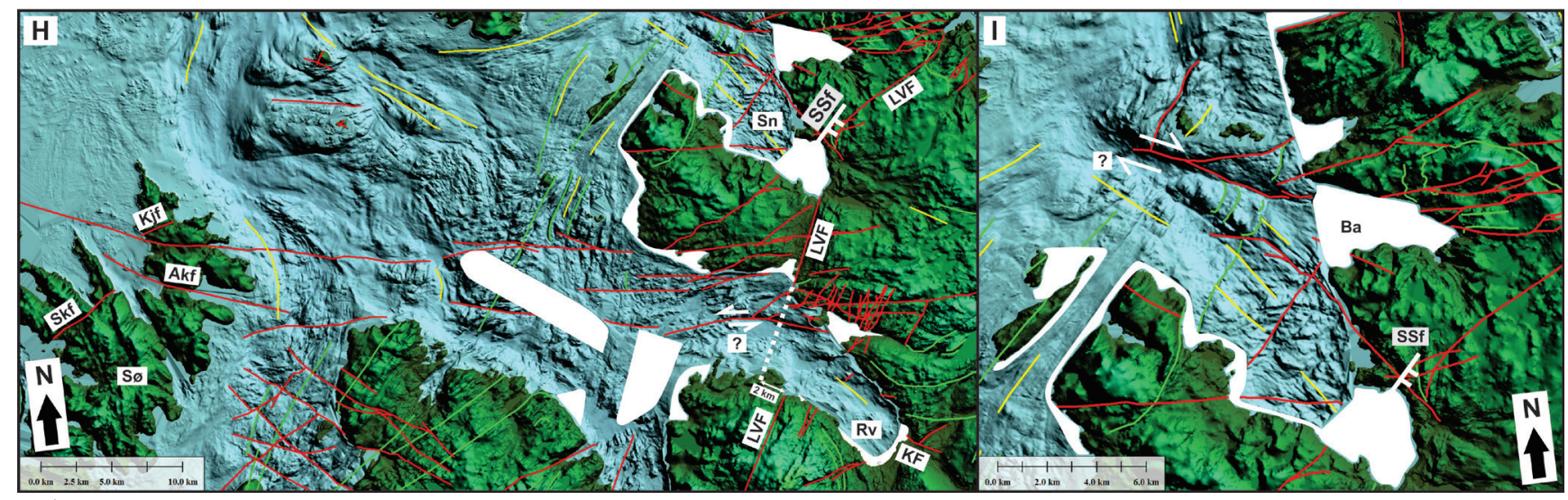

Figure 7. (A) Satellite image of the Porsanger Peninsula (PP) showing dominant WNW-ESE- and ENE-WSW-trending lineaments (red lines). Location is shown in Fig. 2. (B) Satellite image of the central part of the Porsanger Peninsula displaying major lineaments (dashed white) corresponding to a segment of the LVF between Snøfjorden and Ryggefjorden. Location shown as a white frame in (A). (C) Satellite image showing rhomboid-shaped structures formed bounded by WNWESE to E-W- and NE-SW to ENE-WSW-trending lineaments (dashed red and white lines) in the central part of the Porsanger Peninsula. The presumed trace of the LVF is marked by a dashed red line. Location shown in (B). (D) Satellite image northeast of Repparfjorden showing a large lineament possibly representing the LVF (dashed red line) along a river gully where NE-SW- to N-S-striking normal faults crop out (black lines). Ductile Caledonian fabric is shown in dotted green lines. Location is shown in (A). (E) Tilt-derivative in Vargsundet (V) and Repparfjorden (Re) showing a NE-SW-trending positive anomaly (dashed white line) correlating with the Vargsundet segment of the LVF. The anomaly widens and dies out north of Repparfjorden. Note the outline of a large $\mathrm{NE}-\mathrm{SW}$-trending fold structure (dotted white and black lines) mapped by Reitan (1963) in Proterozoic rocks of the Repparfjord-Komagfjord tectonic window. (F) Bathymetry data showing cross-cutting brittle faults (red) with associated inferred movements (white arrows) west of Kvaløya (K). Dotted green lines represent NNE-SSW-trending corrugations that correlate with Caledonian bedrock fabrics onshore Kvaløya. Location in Fig. 4. (G) Outcrop photograph of the Snøfjorden-Slatten fault core made up of oxidised cataclasite and fault gouge (dashed white lines). Location displayed in (B). (H) Bathymetry data showing multiple E-Wtrending fault-related submarine escarpments in Revsbotn (Rv) linking up with E-W-to ENE-WSW-striking faults eastwards, on the Porsanger Peninsula, and with WNW-ESE-striking faults (e.g., the Akkarfjord fault; Akf) westwards, in Sørøya (Sø). The LVF possibly steps left c. $2 \mathrm{~km}$ across these escarpments (white arrows and dotted white line). Bedrock foliation trends are shown in green and glacial plough marks in yellow. Outcrop occurrence of the Snøfjorden-Slatten fault (SSf) is marked by a white line. (I) Bathymetry data showing fault-related submarine escarpments (red lines), bedrock foliation (green lines) and glacial ploughmarks (yellow lines) in Snøfjorden. The outcrop occurrence of the SnøfjordenSlatten fault (SSf) is shown as a white line. In Bakfjorden (Ba), southward clockwise curving of onshore and nearshore ENE-WSW-striking faults possibly indicates dextral strike-slip movement along a major WNWESE-striking fault (white arrows). $\mathrm{km}$-wide depression, the Ryggefjorden trough, are observed on bathymetric data (Figs. 1 \& 10A-D). In map view, the Ryggefjorden trough has an asymmetric sigma shape essentially resulting from the arcuate geometry of a large WNW-dipping escarpment that bounds the trough to the southeast and abruptly curves into a N-S trend at the northeastern end of Ryggefjorden (Fig. $10 \mathrm{~A}-\mathrm{D})$. The sigma shape of the trough is controlled by a few, major, steeply dipping, NNE-SSW-trending escarpments and subsidiary ENE-WSW-trending escarpments (Fig. 10A-D). In the northwestern part of the trough, major scarps dip to the east-southeast, whereas escarpments in the southeastern part dip westnorthwestwards (Fig. 10C-E). These major oppositely dipping escarpments accommodate significant drops of relief within the trough, separating a series of gently dipping rugged terraces that gradually deepen towards the centre of Ryggefjorden (Fig. 10E). Since the bedrock foliation in the area is largely sub-horizontal (Fig. 10E; Roberts, 1998), we interpret the steep escarpments in the Ryggefjorden trough as brittle normal faults and the gently dipping, rugged terraces as eroded, tilted, dominolike fault-blocks. Southwestwards, on the Porsanger Peninsula, the main southeastern boundary-fault of the Ryggefjorden trough merges with NE-SW-trending lineaments representing the northeastern extension of the Snøfjorden-Slatten fault (Fig. 9B) and, thus, may also be part of the LVF. In the northeastern part of the trough, the southeast boundary-fault displays an undulating geometry in map-view and is clearly cross-cut by troughinternal ENE-WSW-trending escarpments that die out to the northeast (Fig. 10A-D). We ascribe the switch from linear to undulating geometry of the southeastern boundary-fault of the trough to minor movement along ENE-WSW-striking faults (Fig. 10A-D), suggesting that faulting along ENE-WSW-striking faults occurred subsequently to the formation of NNE-SSW-striking faults.

Detailed interpretation of bathymetry data further shows that WNW-dipping faults in Ryggefjorden consistently curve anticlockwise into a $\mathrm{N}-\mathrm{S}$ trend to the northeast (Fig. 10A, C) and extend northwards as arcuate NNWSSE- to NNE-SSW-trending escarpments bounding a 


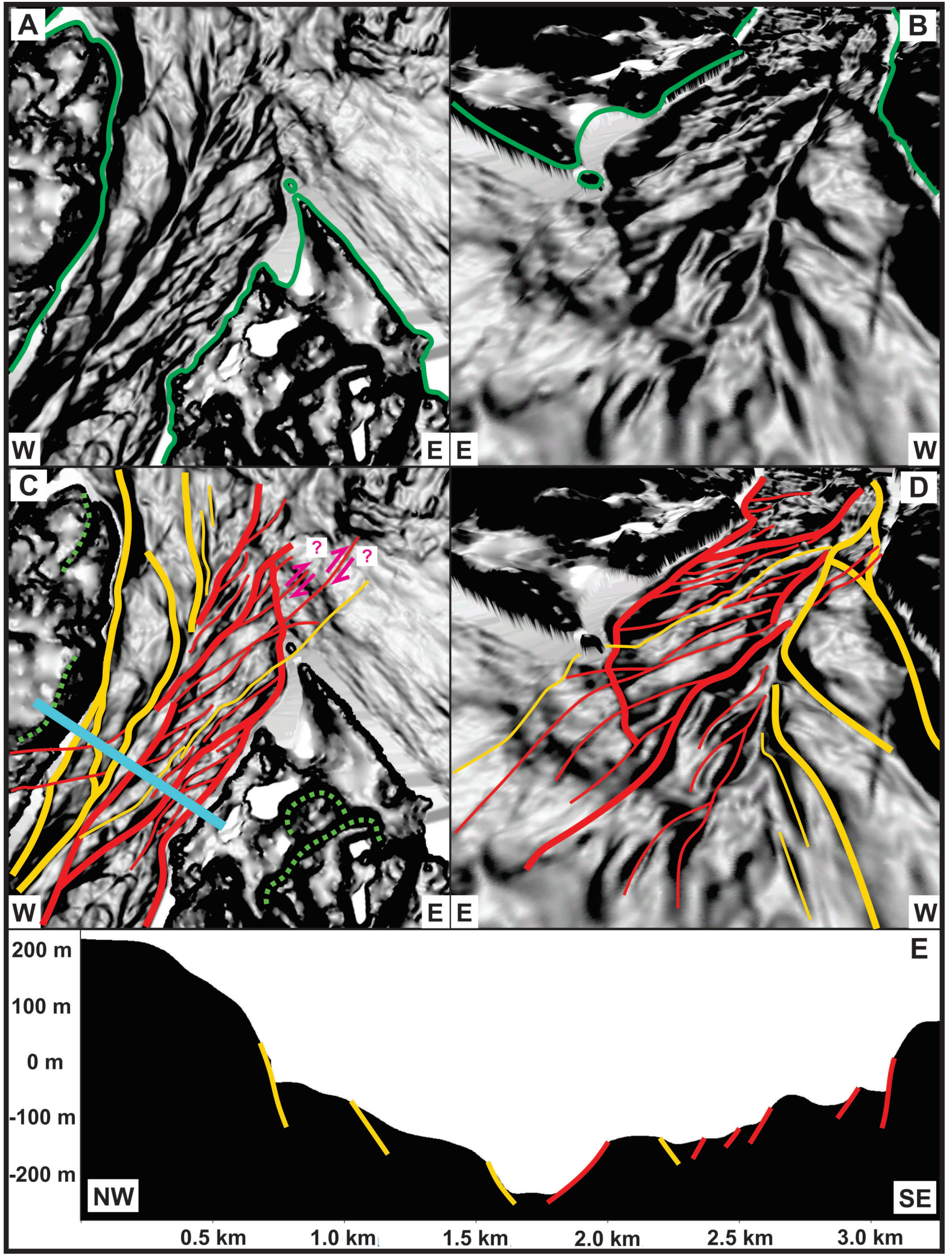

Figure 10. Non-interpreted $(A \& B)$ and interpreted $(C \& D)$ bathymetry data northeast of the Porsanger Peninsula, in Ryggefjorden (see Fig. 4 for location), showing a network of steep, interconnected, $N W$ - and SE-dipping escarpments forming a deep trough on the strandflat, the Ryggefjorden trough. $(A)$ and $(C)$ are map views whereas $(B)$ and $(D)$ are $3 D$ views towards the south. The coastline is marked as a green line in (A) and (B). Bathymetry data in $(A-D)$ are shown using a slope shader with steep slopes in darker and gentle slopes in lighter shades. Note small gaps between the onshore and nearshore data in $(B)$ and $(D)$. Red lines symbolise NW- to west-dipping escarpments and orange lines represent east- to SE-dipping escarpments, both of which we interpret as brittle faults. The southeastern boundary fault of the Ryggefjorden trough displays an arcuate geometry, curving from a NNE-SSW trend in the southwest to a N-S trend in the northeast. The undulating geometry of the northern portion of this fault may be related to minor lateral movement along ENE-WSW-striking faults (pink arrows). The bathymetry-topography profile displayed in (E) shows a gradual deepening of the trough towards the centre of the fjord through a succession of NW-(red) and SE-dipping (yellow) fault-related escarpments, resulting in a graben-like geometry in cross-section. The profile location is shown in blue in (C). 
series of left-stepping sigma-shaped troughs that can be traced to the apex of a large glacial fan (Vorren et al., 1986) near the shelf-break, west of Magerøya (Fig. 11A). We propose that these arcuate escarpments bounding left-stepping, sigma-shaped troughs represent brittle faults analogous to those bounding the Ryggefjorden trough and, thus, may belong to the LVF (Fig. 11A).

\section{Faults on Magerøya}

Metasedimentary and mafic plutonic rocks of the Magerøy Nappe are truncated by a series of dominant WNW-ESE-trending (see next section) and subsidiary ENE-WSW-trending lineaments (Fig. 11B), such as the NNW-dipping Magerøysundet fault (Figs. 1 \& 2) mapped during construction of the subsea tunnel between Magerøya and the Porsanger Peninsula (Rykkelid, 1992). Field studies on Magerøya show two prominent sets of steeply dipping faults trending ENE-WSW and WNWESE, while NNE-SSW-striking faults are scarce (Figs. 2,3 \& 11B). Exceptions occur, e.g., in a quarry within gabbroic rocks of the Honningsvåg Suite, where ENEWSW- and NNE-SSW-striking fractures are relatively abundant (Fig. 11D). Kinematic analysis of slickensided, ENE-WSW-striking fault surfaces reveal dominant sinistral- to dextral-normal oblique-slip movements, notably including a significant strike-slip component (Fig. 3), while a few NNE-SSW-striking faults yield normal dip-slip sense of shear. In northeastern Magerøya (Helnes), ENE-WSW-striking faults and lineaments are truncated by presumably younger, laterally continuous, WNW-ESE-striking faults (Fig. 11E). However, opposite cross-cutting relationships were also observed (e.g., Fig. 11D), advocating synchronous formation of ENE-WSWand WNW-ESE-striking brittle faults.

In southwestern Magerøya, the Magerøy Nappe and a major granite body, the Finnvik Granite (Andersen, 1981), disappear across the fjord to the southwest, where the Magerøysundet fault is thought to bend clockwise into a WNW-ESE strike and significantly downthrow the Magerøy Nappe and Finnvik Granite to the northeast (Andersen et al., 1982). However, aeromagnetic data in southern Magerøya do not support this speculated downfaulting (Fig. 11F), because the negative anomaly associated to the Finnvik Granite can be traced continuously into the Magerøysundet fjord in the southwest and does not appear to be offset (Fig. 11F). In addition, satellite images show a major E-W-trending escarpment cross-cutting rocks of the Kalak Nappe Complex (Fig. 11C). Thus, we propose that the NNWdipping Magerøysundet fault observed in the tunnel to Magerøya (Rykkelid, 1992) rather extends westsouthwestwards onto the Porsanger Peninsula (Fig. 11C) rather than into the Magerøysundet fjord as proposed by Andersen et al. (1982).

\section{WNW-ESE striking faults}

\section{Faults on Magerøya}

WNW-ESE-trending lineaments are most abundant on the island of Magerøya, i.e., near the trace of the TKFZ, and on the Porsanger Peninsula (Figs. 1, 2 \& 3). Satellite images show that the topography on Magerøya is largely controlled by steep, regional, WNW-ESE- (and subsidiary ENE-WSW-) striking lineaments arranged in rhomboid-shaped to anastomosing geometries (Figs. 11B \& 12A). At outcrop scale, WNW-ESEtrending escarpments correlate with dense networks of subparallel, (sub)vertical brittle faults and fractures (Fig. $12 \mathrm{~A}, \mathrm{~B})$ commonly appearing as metre- to hundreds of metre-scale fault corridors and joint swarms (Gabrielsen \& Koestler, 1987), e.g., at Helnes (Fig. 11E) and along the southern shore of Tufjorden in the west (Fig. 12A), in places intruded by dolerite dykes (Roberts et al., 1991) and occasionally forming half-graben structures in cross-section (Fig. 12C). Swarms of WNW-ESEstriking faults (Fig. 12B) generally show limited displacement in the order of a few centimetres, with up to $0.5 \mathrm{~m}$-thick lenses of calcite-cemented cataclasite (Fig. 12C). Slickensided fault surfaces indicate dominant sinistral strike-slip and subordinate oblique-normal sense of shear (Fig. 3). The dominance of sinistral strike-slip kinematics is supported by tens of metre leftlateral offsets of a felsic intrusion in the Magerøy Nappe and by the offset of the contact between the Magerøy Nappe and the Kalak Nappe Complex along WNWESE-striking faults in western Magerøya (Andersen, 1981). Merging-anastomosing geometries combined with contrasting dextral and sinistral strike-slip motion suggest a synchronous formation as conjugate sets for ENE-WSW- and WNW-ESE-striking faults. In addition, the interaction of these two fault sets onshore Magerøya forms S-shaped rhomboidal geometries (Fig. 11A, B \& E) that are comparable in shape, size and trend to strike-slip duplexes along the TKFZ on the Varanger Peninsula (Siedlecki, 1980; Karpuz et al., 1993; Herrevold et al., 2009). Thus, we interpret S-shaped rhomboidal structures on Magerøya as (sinistral) strike-slip duplexes.

Outcrop studies of deformation structures in a quarry in mildly foliated gabbroic rocks of the Honningsvag Suite show ductile shear zones comprising tight, partly offset, asymmetric Z-shaped folds and minor shear bands (Fig. 12D). These Z-shaped folds are interpreted as drag folds formed by top-NE thrusting (see orange marker and upper-right frame in Fig. 12D), i.e., oblique to Caledonian nappe transport directions in general. The Caledonian-oblique thrust is overprinted by a lowangle, SW-dipping brittle fault comprising thin lenses of cataclasite and displaying slickenside lineations that indicate an oblique normal-dextral down-SW sense of shear (Figs. 11D \& 12D), suggesting that the ductile thrust was reactivated during post-Caledonian extension. Adjacent listric SW-dipping brittle faults 


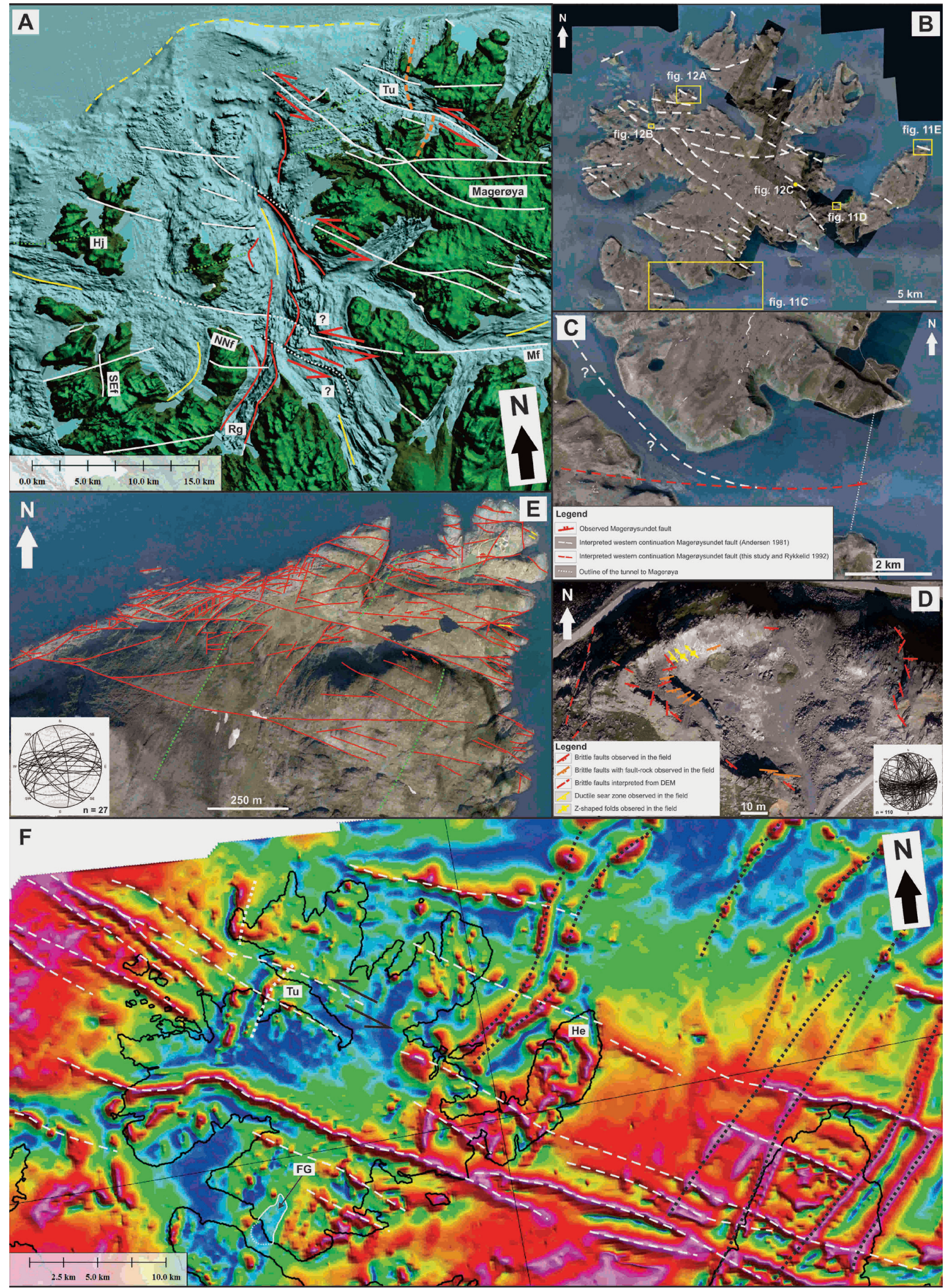


Figure 11. (A) Shallow shelf and fjord bathymetry between Magerøya and the Porsanger Peninsula (location in Fig. 4). Note the alignment of left-stepping sigma-shaped submarine troughs, including the Ryggefjorden trough, in Ryggefjorden (Rg) and west of Magerøya. The troughs are separated by WNW-ESE-trending submarine escarpments merging with onshore lineaments interpreted as brittle faults (white lines). Inferred shear senses displayed as red arrows. Orange dashed lines in northwestern Magerøya delineate the thrust contact between the Kalak Nappe Complex and Magerøy Nappe, which appears laterally offset leftlaterally by c. 3-4 km across a major WNW-ESE-trending fault-related escarpment in Tufjorden (Tu). Bedrock foliation is shown as dotted green lines and glacial ploughmarks as yellow lines. The dashed yellow line displays the contours of a large glacial delta fan (Vorren et al., 1986). (B) Satellite image of the island of Mageroya, which topography is controlled by WNW-ESE- to ENE-WSW-trending lineaments (dashed white lines). Location is shown in Fig. 2. (C) Detail of southern Magerøya showing the western continuation of the Magerøysundet fault according to Rykkelid (1992; red) and Andersen et al. (1982; white). See (B) for location. (D) Outcrop map of brittle faults in a quarry within the Honningsvåg Suite showing an anomalous dominance of ENE-WSW- and NNE-SSWstriking faults (see fracture surface stereoplot in lower-right corner). Location shown in (B). (E) Satellite image of Helnes in eastern Magerøya showing a dominance of WNW-ESE- and E-W- to ENE-WSWstriking fault-related lineaments, while NNE-SSW-striking faults are subsidiary (see fracture surface stereoplot in lower left corner). The bedrock is composed of gabbros from the Honningsvåg Suite and schists and metavolcanics of the Mageroya Nappe. Dominant ductile fabrics are drawn as dotted green lines. Exposed Caledonian mafic dykes are marked in yellow. Location displayed in (B). (F) Tilt derivative in Magerøya displaying numerous linear WNW-ESE-trending positive anomalies (dashed white lines) correlating with dolerite dyke swarms intruded along brittle faults. These faults cross-cut and laterally offset NNE-SSWtrending positive anomalies (dotted black lines) interpreted as magnetiterich metasedimentary units (Roberts \& Siedlecka, 2012; Roberts \& Williams, 2013). In Tufjorden (Tu), the thrust contact between the Magerøy Nappe and Kalak Nappe Complex (dotted white lines) coincides with a discontinuous NNE-SSW-trending positive anomaly that is offset left-laterally by a WNW-ESE-trending aeromagnetic lineament (see black arrows), which extends westwards as a dyke-related positive anomaly and, thus, may represent a brittle fault. In the southern part of Magerøya, a negative anomaly (thin white and dotted line) correlates with the outcrop occurrence of the Finnvik Granite (FG; Andersen, 1981), and extends within the fjord.

displaying comparable kinematic indicators and merging downwards into one another may have formed during the inversion of the thrust as subparallel extensional splay-faults (Figs. 11D \& 12D).

Analysis of bathymetry data west of Magerøya reveals pervasive, ENE-WSW-trending corrugations (green dotted lines in Fig. 11A). Northeastwards across Tufjorden (Fig. 1), these ENE-WSW-trending corrugations curve into a NNE-SSW trend (Fig. 11A) that coincides with a similar switch in trend of the dominant Caledonian bedrock fabrics onshore Magerøya (Andersen, 1981). On the strandflat west of Magerøya, these presumed Caledonian fabric corrugations are cross-cut by laterally continuous, WNW-ESE-trending gullies that correlate with major WNW-ESE-striking faults and lineaments onshore Magerøya (Fig. 11A). The largest WNW-ESE-trending gully occurs in Tufjorden parallel to the fjord coastline (Fig. 11A), and is bounded to the south by a steep NNE-dipping escarpment that accommodates a major drop of topography. On satellite images, this escarpment parallels a large, WNW-ESEtrending lineament interpreted as a major brittle fault onshore Magerøya (Fig. 12A), thus supporting our interpretation of WNW-ESE-trending gullies nearshore Magerøya as brittle faults. Bathymetry data show that the WNW-ESE-striking fault in Tufjorden offsets the Caledonian nappe contact between the Magerøya Nappe and the Kalak Nappe Complex by c. 2-3 km left-laterally (Fig. 11A; Andersen, 1981; Robins, 1990a). On tilt-derivative data, the nappe contact is outlined by a system of narrow, NNE-SSW-trending positive and negative anomalies that extend across Tufjorden to the north and are offset c. 3-4 km left-laterally below the nappe contact (Fig. 11F), which is comparable to the interpreted offset on bathymetry data (Fig. 11A). The mismatch between the location of the main WNW-ESEstriking fault on bathymetry data and the actual step/ offset of aeromagnetic anomalies may be caused by the northeastwards dip of the main fault combined with aeromagnetic imaging of a deeper portion of the fault (Fig. 11F). Thus, we propose that the offset of the nappe contact in Tufjorden is related to sinistral strike-slip to sinistral-normal oblique-slip movements along the interpreted WNW-ESE-striking brittle fault (Fig. 11A). This is consistent with dominant sinistral strike-slip shear senses along WNW-ESE-striking faults onshore Magerøya (Fig. 3). Dominant left-lateral strike-slip movements are further indicated by the left-stepping geometry of sigma-shaped troughs and associated bounding faults on the strandflat west of Magerøya (red lines in Fig. 11A), which seem to step by $>1 \mathrm{~km}$ across WNW-ESE-trending, fault-related, submarine escarpments (white lines in Fig. 11A).

Aeromagnetic data in this area (Nasuti et al., 2015b) also show a c. $15 \mathrm{~km}$-wide NNE-SSW-trending positive anomaly below the Ryggefjorden trough and the extension of the trough to the south onto the Porsanger Peninsula (Fig. 12E). Northwards, this $15 \mathrm{~km}$-wide positive anomaly steps several kilometres to the northwest, which is similar to the attitude of left-stepping sigma-shaped troughs on bathymetry data (Fig. 11A). The left step of this positive aeromagnetic anomaly (Fig. $12 \mathrm{E})$ coincides with a large escarpment on bathymetry data that merges into major fault-related lineaments onshore Magerøya (Fig. 11A, B), thus suggesting the left-step of the wide positive aeromagnetic anomaly to be related to sinistral strike-slip offset along a major WNW-ESE-striking brittle fault (Fig. 12E), which is in accordance with dominant kinematic indicators along similarly trending faults on Magerøya (Fig. 3).

Bathymetry data nearshore Helnes, east of Magerøya, show NNE-SSW- to NE-SW-trending escarpments (green lines in Fig. 12F) arranged subparallel to gently ESE-dipping bedrock foliation onshore Magerøya (Andersen, 1981). These escarpments of Caledonian 


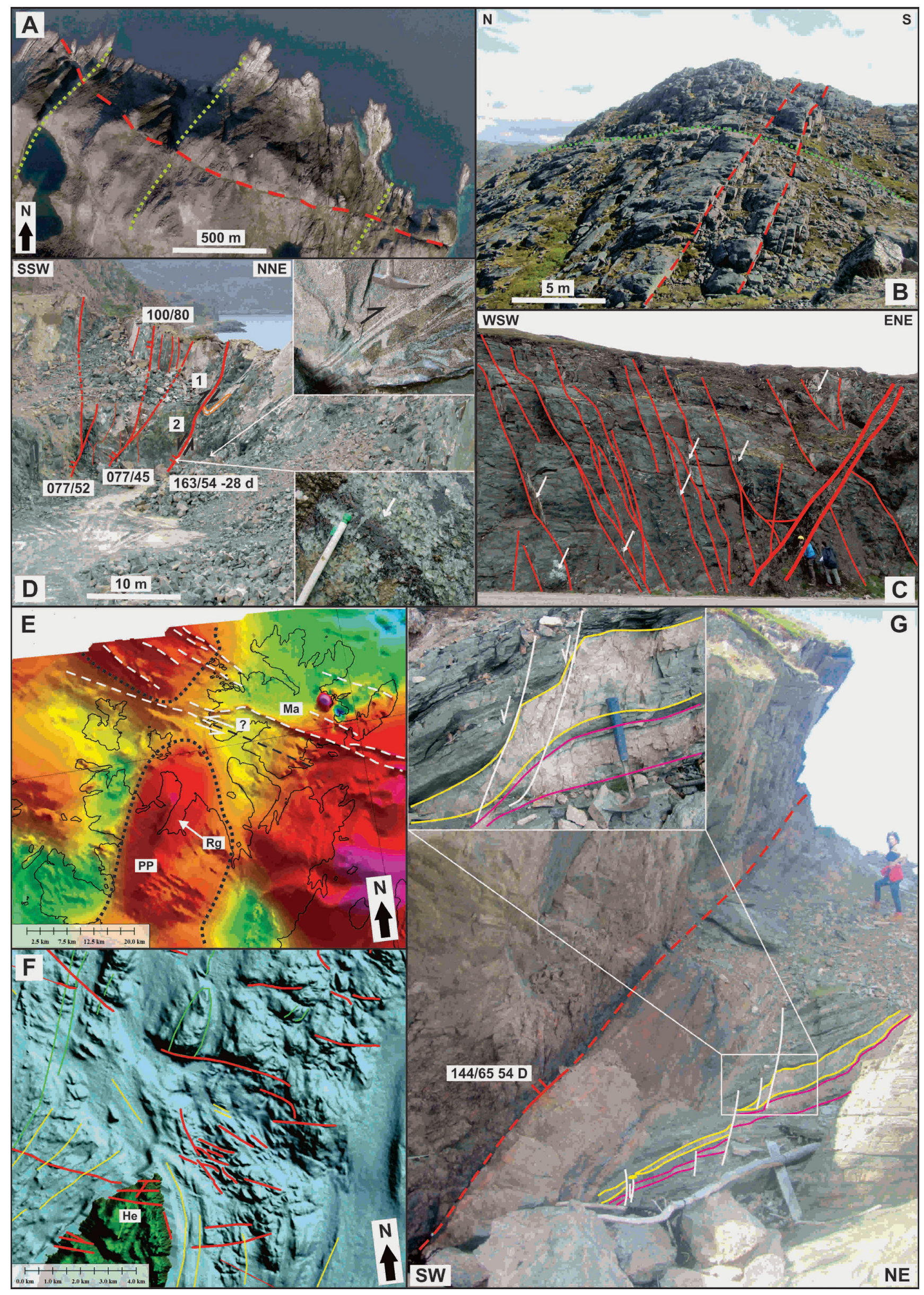


Figure 11. (A) Satellite image of a prominent WNW-ESE-trending faultrelated lineament (dashed red line). Bedrock foliation is shown as dotted green lines. Location along the southern coast of Tufjorden on Magerøya (Fig. 11B). (B) Pervasive subvertical WNW-ESE-striking fractures (e.g., in dashed red lines) cross-cutting schists of the Kalak Nappe Complex in western Magerøya. ESE-dipping Caledonian fabrics shown as a dotted green line. Location is shown in Fig. 11B. (C) Half-graben structure bounded by WNW-ESE-striking brittle faults comprising calcite-rich cataclasite (white arrows) in schists of the Magerøy Nappe in central Magerøya. Location is shown in Fig. 11B. (D) Listric faults (red lines) comprising 10-50 cm-thick lenses of cataclasite. Associated structural measurements in white boxes. A bolt-shaped felsic bed (orange) may indicate drag-folding along an adjacent $S W$-dipping ductile shear zone (upper inset), suggesting (1) top-NE ductile thrusting and, later on, (2) down-SW brittle normal reactivation (see slickensided fault surface, i.e., white arrow, in lower right inset). (E) NE-SW-trending positive aeromagnetic anomaly (dotted black line) in the Porsanger Peninsula $(P P)$ seemingly offset between Ryggefjorden $(\mathrm{Rg})$ and Magerøya (Ma). The apparent, $\mathrm{km}$-scale left-lateral offset may reflect sinistral strike-slip movement (white arrows) along a WNW-ESE-striking fault (dashed white) that can be traced eastward onshore Magerøya (Ma; dashed black line). (F) Bathymetry data north of Helnes (He; see Fig. 4 for location) revealing the presence of a Z-shaped trough bounded by WNW-ESEand NNW-SSE-striking fault-related escarpments (red). (G) Storhaugen fault core (red line), and adjacent footwall damage zone (inset box) where alternating felsic and mafic gneissic units (yellow and pink lines) are downthrown along minor synthetic normal faults (white lines and arrows). Location is shown in Fig. 2.

fabrics coincide with similarly trending positive anomalies on aeromagnetic data (Fig. 11F) and are crosscut by a network of interacting, prominent, WNWESE-trending and subsidiary NNW-SSE-trending escarpments that create a Z-shaped rhomboidal trough (red lines in Fig. 12F) that aligns with dominant fault trends onshore Magerøya (Fig. 3). This Z-shaped trough is similar to potential rhomboid-shaped strike-slip duplexes onshore Magerøya (Fig. 11A, B) and duplexes along the TKFZ on the Varanger Peninsula (Siedlecki, 1980; Karpuz et al., 1993), thus suggesting that WNWESE-striking faults nearshore Helnes are part of duplexes that accommodated strike-slip to oblique-normal movements. This is also consistent with the analysis of slickenside lineations along WNW-ESE striking faults on Magerøya (Fig. 3). We propose that the nearshore rhomboidal trough in Helnes (Fig. 12F) developed as a small-scale pull-apart basin along the westwards continuation of the TKFZ. An additional argument to link WNW-ESE-striking faults onshore-nearshore Magerøya to the TKFZ is the linkage of multiple, narrow, WNW-ESE-trending, positive aeromagnetic anomalies on Magerøya (Figs. 5A, B \& 11F), which represent Carboniferous dolerite dykes arranged in relay pattern (i.e., inconsistently overlapping or underlapping and subparallel; Harding \& Lowell, 1979; Biddle \& ChristieBlick, 1985; Christie-Blick \& Biddle, 1985) and intruded along WNW-ESE-striking brittle faults (Roberts et al., 1991; Nasuti et al., 2015a), to analogous anomalies on the Varanger Peninsula (key locality of the TKFZ). These anomalies truncate NNE-SSW- to NE-SW-trending submarine escarpments (Fig. 12F) and subparallel positive aeromagnetic anomalies representing Caledonian fabrics (Fig. 11F; Roberts \& Siedlecka, 2012), and extend onshore Helnes where they correlate with large, WNW-ESE-striking, fault corridors (Figs. 11E \& $12 \mathrm{~F})$. These fault corridors suggest that fault segments of the TKFZ continue westwards onshore Magerøya at Helnes (Figs. 4, 5A, B \& 11F).

\section{Faults on the Porsanger Peninsula}

The Porsanger Peninsula is incised by several large ENEWSW- and WNW-ESE- to NW-SE-trending fjords that penetrate and truncate the gently dipping bedrock foliation of the Kalak Nappe Complex (Fig. 9H, I). The dominant surface lineaments trending WNW-ESE and ENE-WSW largely overlap with exposed and inferred onshore brittle faults (Figs. 2 \& 9A). For example, the NNE-dipping Kokelv Fault defines a series of NW-SEto WNW-ESE-trending escarpments in the southern part of the Porsanger Peninsula (Fig. 9A). This fault strikes subparallel to the TKFZ and downthrows rocks of the Kalak Nappe Complex to the northeast (Gayer et al., 1985; Lippard \& Roberts, 1987). Outcrops near the trace of the Kokelv Fault and on the western coastline of the Porsanger Peninsula support the existence of pervasive, subvertical, NW-SE-striking fractures similar to those observed on Magerøya. These fractures display limited amounts of lateral offset, generally $<2 \mathrm{~m}$. Slickensided fault surfaces suggest that NW-SE-striking faults accommodated dominant sinistral and subsidiary dextral strike-slip movements (Fig. 3). Locally, fault-rock composed of cataclastic lenses and clay-rich fault gouge was found along low-angle listric faults.

Bathymetry data in Snøfjorden, west of the Porsanger Peninsula (Fig. 1), show large WNW-ESE- to NWSE-trending escarpments (Fig. 9I) that coincide with onshore-nearshore topographic troughs. In map-view, large ENE-WSW-striking brittle faults curve clockwise and merge into these WNW-ESE- to NW-SE-trending escarpments (Fig. 9I), suggesting that the latter represent dextral strike-slip faults, which might have drag-folded presumably older ENE-WSW-striking faults. Dextral motion is supported by recorded kinematic indicators on similarly trending faults on the Porsanger Peninsula (Fig. 3).

Farther west, between the islands of Kvaløya and Sørøya (Fig. 1), bathymetry data show several NW-SE- to WNW-ESE- and E-W- to ENE-WSW-trending linear escarpments (Fig. 9F). The former may be traced eastsoutheastwards onshore Kvaløya where they line up with WNW-ESE-trending linear valleys and lineaments (Fig. 9F). These two sets of linear escarpments trend oblique to the dominant NE-SW-trending bedrock foliation on Kvaløya (Jansen et al., 2012), which is also seen as a large number of corrugations in the adjacent fjord (Fig. 9F), and are therefore interpreted as brittle faults. West of Kvaløya, a c. 170 m-wide, right-lateral offset of an ENE-WSW- to NE-SW-striking fault and $400 \mathrm{~m}$-wide, 
left-lateral offset of a NW-SE-striking fault, respectively, indicate dextral strike-slip motion along a WNW-ESEstriking fault and sinistral strike-slip movement along an ENE-WSW-striking fault (Fig. 9F). Thus, WNW-ESEand ENE-WSW-striking faults laterally offset each other and may have formed synchronously as conjugate sets.

\section{Faults in Langfjorden-Altafjorden}

At the intersection of Langfjorden and Altafjorden (Fig. 1), the LVF defines a major map-view bend from an ENE-WSW trend in Langfjorden to a NNE-SSW trend in Vargsundet (Figs. 2 \& 7G). At the easternmost tip of Langfjorden, a low-angle SW-dipping fault, the Storhaugen fault (Marti, 2013), is exposed near the shoreline (Figs. $2 \& 12 \mathrm{G}$ ). The fault cross-cuts felsic and mafic metasedimentary units of the Kalak Nappe Complex (Fig. 12G) and strikes oblique to the LVF and sub-parallel to the TKFZ and Kokelv Fault (Fig. 2). Slickenfibres and asperities found along the main fault surface indicate a normal-sinistral oblique-slip sense of shear (Fig. 12G). Moreover, the host-rock fabrics in the footwall of the fault curve and merge into the brittle fault fabric, which is interpreted as drag-folding due to normal motions along the fault. This is consistent with $\mathrm{cm}$ - to $\mathrm{dm}$-scale normal offsets of foliation surfaces across minor brittle fault splays in the footwall of the fault (Fig. $12 \mathrm{G})$.

The Storhaugen fault can be traced into Altafjorden as one of several, steep, WSW-dipping escarpments (Fig. $7 \mathrm{G})$. Southwards, these escarpments correlate onshore with steeply SW-dipping, macro-folded, Proterozoic, volcano-sedimentary units of the Alta-Kvænangen tectonic window (Fig. 7G; Roberts, 1973; Zwaan \& Gautier, 1980). Aeromagnetic data in Altafjorden show that the Storhaugen fault and related submarine escarpments line up with a NNW-SSE-trending positive anomaly (Fig. 8A, B). We interpret this anomaly to represent a steeply WSW-dipping metavolcanic unit in the Alta-Kvænangen tectonic window, which we previously correlated with an analogous unit on the eastern shore of the fjord in the Altenes tectonic window (Fig. 8A, B). This unit clearly appears to form a steeply NW-plunging antiform fold structure in Altafjorden. Thus, we propose that the Storhaugen fault formed along the favourably oriented western limb of a Proterozoic fold at depth, and propagated upwards into the overlying Kalak Nappe Complex (Fig. 8A, B).

Bathymetry data between Altafjorden and the Sørøy sub-basin show a prominent WNW-ESE-trending escarpment that bounds the Sørøy sub-basin to the southwest and extends eastwards into Altafjorden, coinciding with a major counterclockwise bend in trend of the LVF (Figs. $1 \& 7 \mathrm{H}$ ). This major escarpment trends parallel to the TKFZ and we interpret it as a large WNW-ESE-striking brittle fault. On tilt-derivative data, this major lineament coincides with a narrow negative anomaly, which supports an interpretation as a brittle fault (Fig. 8B, C).

\section{Discussion}

In the discussion below we address and argue for the extent and linkage of segments and splays of the two major fault complexes LVF and TKFZ and associated faults in NW Finnmark, the interaction of the two fault systems, controlling basement fabrics and structures, timing constraints, and their relationship to rhomboidalsigma-shaped nearshore basins and offshore zigzagshaped fault complexes.

\section{Architecture and extent of the Langfjorden-Varg- sundet fault}

Thus far, the LVF was correlated from Langfjorden to Vargsundet and Revsbotn (Lippard \& Roberts, 1987; Roberts \& Lippard, 2005). We propose to expand this correlation and extend the LVF farther northeast and farther southwest. First of all, in Langfjorden, the presence of a major NW-dipping normal fault named the LVF is supported by submarine escarpments on bathymetry data (Figs. $4 \& 7 \mathrm{G}$ ) and by narrow, zigzagshaped, negative anomalies on tilt-derivative data (Fig. $8 \mathrm{~B})$, indicating an abrupt lithological transition below the fjord (Fairhead et al., 2008). Further arguments include the juxtaposition of rocks of the Seiland Igneous Province against rocks of the Kalak Nappe Complex across Langfjorden (Fig. 1; Roberts, 1973; Zwaan \& Roberts, 1978), and geophysical data indicating a very deep (up to $9 \mathrm{~km}$ ) root for the Seiland Igneous Complex (Pastore et al., 2016), i.e., possibly downthrown several $\mathrm{km}$ to the northwest by the LVF.

Near the mouth of Altafjorden, the LVF abruptly curves into a NNE-SSW trend (Figs. $2 \& 7 \mathrm{G}$ ) before bending into ENE-WSW trend again in VargsundetRepparfjorden (Fig. 9D, E). This bend is well constrained by a linear fjord-bottom escarpment in Langfjorden and Vargsundet (Figs. 4 \& 7G) and supported onshore by numerous fault splays with similar shifts in orientation and comparable normal dip-slip to obliqueslip kinematic characters (e.g., the Øksfjorden and Storekorsnes faults; Figs. 2, 3, 6C-G, 7 \& 9D). In addition, the arcuate-shaped Øksfjorden fault (Fig. 7B, C) and the zigzag shape of the southeastern boundary fault of the Sørøy sub-basin (Figs. 7H \& 8C) support the bending attitude of margin-parallel brittle faults in this area and linkage of the LVF from Langfjorden to Vargsundet (Fig. $7 \mathrm{G})$.

The extension of the LVF from Sørkjosen to Vargsundet is supported by abrupt width changes of major NNWSSE-trending aeromagnetic anomalies interpreted as macrofolded Precambrian granite-gneiss and volcanosedimentary metasupracrustal-greenstone belts (Zwaan \& Gautier, 1980; Gautier et al., 1987; Olesen et al., 1990; Bergh et al., 2010; Henderson et al., 2015; Nasuti et 
al., 2015b) across the presumed fault trace (Fig. 5A). These abrupt changes across the LVF may be caused by $\mathrm{km}$-scale, down-NW, normal offsets of NW-SE-trending macrofolded basement, where antiforms made up with granite-gneiss belts (producing positive aeromagnetic anomalies) become narrower to the northwest across the LVF, and are flanked by synforms made up with volcanosedimentary rocks (producing negative aeromagnetic anomalies) that broaden northwestwards across the LVF (Fig. 5A).

Fault-bend-acommodated linkage of the LVF from Vargsundet to Repparfjorden and Revsbotn (Fig. 1) is confirmed by a narrow, positive, aeromagnetic anomaly (Figs. 5A \& 9E) aligned parallel to a prominent NNE-SSW-trending surface escarpment north of Repparfjorden, and further supported by field observations such as normal dip-slip to oblique-slip fault kinematics (Fig. 9D). This escarpment was mapped as a large brittle fault separating two tectonic units of the Kalak Nappe Complex and accommodated down-NW displacement in the order of a few hundreds of metres (Gayer et al., 1985), i.e., comparable to the inferred offset along the LVF in Vargsundet (Zwaan \& Roberts, 1978).

On the Porsanger Peninsula, we interpret the SE-dipping Snøfjorden-Slatten fault and related minor faults between Revsbotn and Snøfjorden (Fig. 9A, G \& H; Passe, 1978; Rice, 1982; Townsend, 1987a) as part of a dip-slip to oblique-slip normal splay-fault formed antithetic to the LVF. East of the Snøfjorden-Slatten fault, the LVF may continue as a suite of interconnected, zigzag-shaped, NNE-SSW- to ENE-WSW-trending, fault-related lineaments possibly merging with the NW-dipping southeastern boundary-fault of the Ryggefjorden trough (Fig. 9A, B), thus suggesting a genetic relationship between the trough and the LVF.

Bathymetry data suggest that the Ryggefjorden trough (Fig. 10) continues as a series of $\mathrm{km}$-scale, left-stepping, sigma-shaped troughs (Fig. 11A). We argue that the several-km width of these troughs and the arcuate geometry of their boundary faults mimic the overall zigzag architecture of the LVF (Fig. 2). Consequently, the Ryggefjorden trough and associated left-stepping, sigma-shaped troughs likely represent graben structures developed along and bounded by the northeastern prolongation of the LVF (Fig. 11A). This is supported by offshore seismic data showing that the LVF extends northeastwards onto the eastern Finnmark Platform, where it appears as a similar, zigzag-shaped, NW-dipping fault bounding a sigma- to rhomboid-shaped Carboniferous graben (Fig. 1; Koehl et al., 2018a).

Considering strong similarities in fault architecture (zigzag shape and listric fault geometries), kinematics (normal dip-slip to oblique-slip) and inferred magnitude of displacement along the LVF and Vestfjorden-Vanna Fault Complex (i.e., a few hundreds of metres to a few kilometres; Indrevær et al., 2013), we argue that they belong to the same fault system. An argument against the Vestfjorden-Vanna Fault Complex and LVF belonging to the same fault complex is that the LVF mainly dips to the northwest, whereas the Vestfjorden-Vanna Fault Complex dips to the southeast. However, opposite dip directions may be explained by linkage of alternating synthetic and antithetic fault strands (Figs. 6, 7, 9 \& 10), and/or a switch in polarity across tentative transfer fault zones (Olesen et al., 1997; Bergh et al., 2007). For instance, Indrevær et al. (2013) argued that the Vestfjorden-Vanna Fault Complex extends offshore and merges with the Måsøy and Nysleppen fault complexes (Fig. 1), and that a shift in polarity between the SE-dipping VestfjordenVanna Fault Complex and NW-dipping Måsøy Fault Complex is due to movement transfer along the Fugløya transfer zone. Nevertheless, the Sørkjosen portion of the LVF extends to the southwest, across the Fugløya transfer zone, as observed in the field (Fig. 6A, B) and on aeromagnetic data (Figs. 5 \& 8B). West of Lyngenfjorden, the LVF possibly links up with the Laksvatn fault, a major NW-dipping inverted Caledonian thrust fault (Fig. 5; Davids et al., 2013) that may have accommodated downWNW extension during the collapse of the Caledonides (Schiffer, 2017) and locally separates the Lyngsfjell and Nordmannvik nappes (Slagstad, 1995; Kvassnes et al., 2004). Thus, we reject the possibility of the VestfjordenVanna Fault Complex and LVF representing fault strands of the same fault complex and, instead, argue that they represent antithetic fault complexes of a single, coastparallel fault system.

\section{Linking segments and splays of the Trollfjorden- Komagelva Fault Zone and associated faults}

The TKFZ is best expressed onshore the Varanger Peninsula in eastern Finnmark (Fig. 1; Siedlecka \& Siedlecki, 1967; Siedlecki, 1980), but can be traced westward between the Nordkinn Peninsula and the mainland, and, supposedly, off the strandflat north of Magerøya (Roberts et al., 2011). In the present chapter, we intend to show that WNW-ESE-striking faults onshorenearshore Magerøya, the Porsanger Peninsula and the Nordkinn Peninsula (Figs. 11A, B, E \& F \& 12A-F) share multiple geometric and kinematic similarities with the TKFZ and may actually represents segments and splays of the TKFZ and/or are part of the same fault system, although previous studies mapped them as independent faults (Andersen, 1981; Lippard \& Roberts, 1987; Siedlecka \& Roberts, 1996) and interpreted the TKFZ to continue offshore north of Magerøya (see "segments 3 and 4" in Gabrielsen \& Færseth, 1989 and Karpuz et al., 1993).

The first hints are given by satellite images of Magerøya and bathymetry data from adjacent fjords, which have revealed that WNW-ESE-striking faults typically form rhomboid-shaped structures in map-view (Figs. 9B, C, 
11A, B \& E \& 12F) similar to duplex structures along the TKFZ on the Varanger Peninsula (Johnson et al., 1978; Siedlecki, 1980; Karpuz et al., 1993; Herrevold et al., 2009). In addition, linear WNW-ESE-striking fractures are abundant both onshore and on bathymetry data east of Magerøya (Figs. 11A-C \& 12A-C). These linear features correspond well with a network of narrow, anastomosing positive aeromagnetic anomalies arranged in relay pattern (Harding \& Lowell, 1979; Biddle \& Christie-Blick, 1985; Christie-Blick \& Biddle, 1985), some of which correlate with swarms of early Carboniferous (Lippard \& Prestvik, 1997) dolerite dykes (Figs. 5A, B, 11F \& 12E; Nasuti et al., 2015a) intruded along and sealing (Roberts et al., 1991) WNW-ESE- to E-Wstriking faults onshore Magerøya. Some of these dykerelated anomalies (Nasuti et al., 2015a) continue and/ or step farther east, some merging with a major positive anomaly that mimics the trace and attitude of the TKFZ on the Varanger Peninsula (Fig. 5B). We interpret this major anomaly as the potential eastwards continuation along the TKFZ of dolerite dyke swarms observed onshore Magerøya (e.g., Roberts et al., 1991).

The linkage of the trace of the TKFZ on the Varanger Peninsula and WNW-ESE-striking faults intruded by dolerite dykes onshore-nearshore Magerøya suggests that these faults all belong to the same major fault system. Thus, we argue that WNW-ESE-striking faults in NW Finnmark, notably onshore-nearshore Magerøya, the Porsanger Peninsula and the Nordkinn Peninsula represent fault segments and splays of the TKFZ and/or fault strands associated with the TKFZ. More specifically, we propose that the TKFZ continues onshore-nearshore the northernmost tip of the Sværholt Peninsula, and westwards onshore Magerøya, possibly onshore-nearshore Helnes and/or in Tufjorden (Figs. $1 \& 13 \mathrm{~A}$ ). This is supported by the presence of a dykerelated positive aeromagnetic anomaly extending from the Varanger Peninsula to the Sværholt Peninsula and Helnes in eastern Magerøya (Figs. 5B \& 11F), by km-wide WNW-ESE-trending fault corridors at Helnes (Fig. 11E), by fault escarpments arranged in Z-shaped duplex-like structure nearshore Helnes (Fig. 12F), by the presence of a major WNW-ESE-striking fault-related escarpment on the southern shore of Tufjorden (Fig. 12A), and by a 3-4 km left-lateral offset of Caledonian nappes across Tufjorden (Fig. 11A, F).

We further argue that WNW-ESE-striking faults interpreted to be related to the TKFZ formed and evolved synchronously with the (TKFZ) main fault trace on the Varanger Peninsula, e.g., being reactivated during latepost-Caledonian extension and providing space for early Carboniferous dolerite dyke intrusions. This is supported by the relay pattern displayed by the dyke-related aeromagnetic anomalies (Figs. 5 \& $11 \mathrm{~F}$ ), the geometry of which is typical of extensional tectonics (Harding \& Lowell, 1979). By comparison, swarms of WNW-ESEstriking early Carboniferous dykes in Finnmark are similar in size (possibly $\mathrm{km}$-scale width for individual swarms, and a several tens of $\mathrm{km}$-wide area affected by the dykes) and shape (rectilinear dyke swarms arranged in relay pattern) to dyke swarms in active rifts, e.g., the Northern Rift Zone in Iceland (Buck et al., 2006; Hjartardóttir et al., 2016). There, dykes partly intruded along preexisting strike-slip faults are similar in length to fault segments and splays of the TKFZ (e.g., the 2014 Bárðarbunnga-Holuhraun dyke intrusion; Ágústsdóttir et al., 2016), thus supporting a pre-Carboniferous origin for strands of the WNW-ESE-striking fault system onshore-nearshore Finnmark.

Our grouping of WNW-ESE-striking faults in NW Finnmark into a single major fault system is further supported by several similarities with major active fault systems, such as that of the San Andreas fault in California, whose fault segments and splays are similar in length (up to $38 \mathrm{~km}$ ) and number (up to 68 major segments; Bilham \& King, 1989) to the faults herein proposed to represent segments and splays of the TKFZ (e.g., Fig. 13A). Furthermore, despite the clear predominance of steeply dipping WNW-ESE-striking faults and fracture swarms on Magerøya (Figs. 3, 11A, B \& E \& 12B), these faults are locally subsidiary, e.g., in Silurian rocks of the Honningsvåg Suite (Corfu et al., 2006; Fig. 11D). This suggests that very few new margin-orthogonal faults formed during late-postCaledonian extension and may therefore further support the notion that WNW-ESE-striking faults on Magerøya are fault strands associated with the TKFZ, some of these representing segments and/or splays of the TKFZ, rather than post-Caledonian faults since this marginoblique fault system was only mildly reactivated after the Caledonian Orogeny (see next paragraphs for further discussion on the TKFZ post-Caledonian movement history).

Most WNW-ESE-striking margin-oblique faults on Magerøya display evidence of sinistral strike-slip movements as shown by slickensided fault surfaces. (Fig. 3). In addition, large-scale evidence includes 3-4 km leftlateral offset of the contact between the Kalak Nappe Complex and the Magerøy Nappe visible on bathymetry and tilt-derivative aeromagnetic anomaly data in Tufjorden (Fig. 11A, F), >10 m offsets of a Caledonian granitic intrusion in western Magerøya (Andersen, 1981), km-scale left-lateral offsets of the Ryggefjorden trough and related troughs (Fig. 11A) and a several km, leftlateral offset of a c. $15 \mathrm{~km}$-wide aeromagnetic anomaly (Fig. 12E). Notably, NNE-SSW-striking faults in the Ryggefjorden trough are offset by several km left-laterally and bent counterclockwise into segments and splays of the TKFZ and fault strands of the associated fault system giving the troughs a sigma-shaped geometry in map view (Fig. 11A). If this map-view pattern is a product of dragrelated bending into WNW-ESE-striking fault segments and splays of the TKFZ and associated fault strands, the left-steps and sigma-shaped geometries of the troughs 


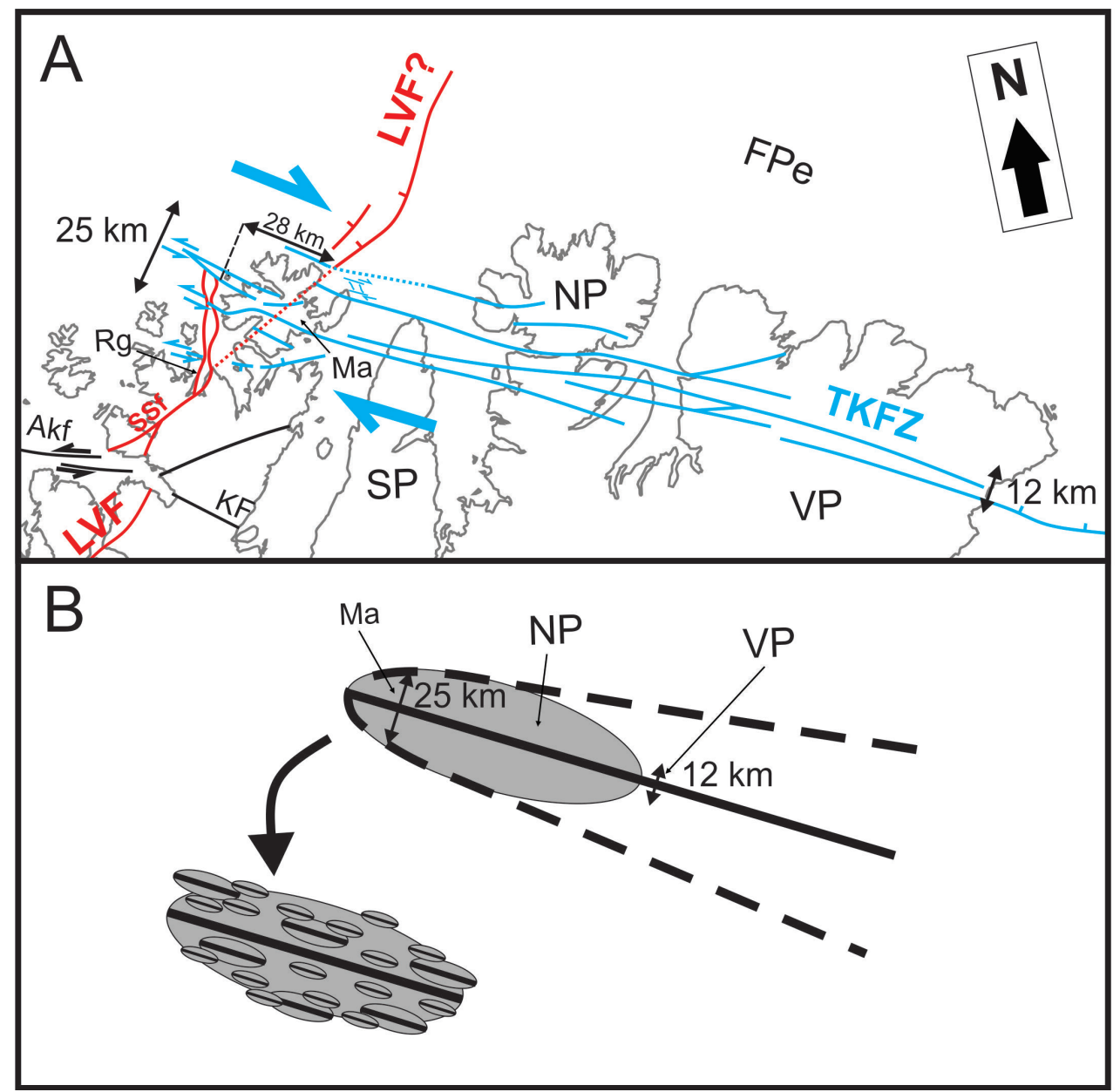

Figure 13. (A) Structural map showing the interaction of the TKFZ and associated fault system (blue) and LVF (red) during late Palaeozoic extension. The Akkarfjord fault and other (conjugate?) faults potentially related to the TKFZ are displayed as black lines. The TKFZ and other associated WNWESE-striking faults offset the LVF by c. $28 \mathrm{~km}$ right-laterally between Ryggefjorden and (Rg) and the eastern Finnmark Platform (FPe; Koehl et al., 2018a). Note that left- and right-lateral offsets of the LVF across fault segments and splays of the TKFZ and other related WNW-ESE-striking faults counter-balance one another so that the onshore-nearshore LVF and the offshore continuation of the LVF remain aligned along a NE-SW-trending axis (dotted red line). Note the significant width variation of the WNW-ESE-striking fault system (including the TKFZ) from the Varanger Peninsula $(c .12 \mathrm{~km})$ to Magerøya (c. $25 \mathrm{~km})$. Abbreviations as in Fig. 1. (B) Conceptual fault-tip process zone model for the TKFZ and associated WNW-ESEstriking fault strands based on Braathen et al. (2013). The process zone is grey-shaded and is composed of a high number of minor subparallel faults. On the Varanger Peninsula (VP), deformation localised along a few major fault segments and splays (fault system with a map-view width of c. $12 \mathrm{~km}$ ), while on Magerøya, deformation distributed along numerous minor faults that accommodated displacement in the order of a few tens of metres to a few kilometres (fault system with a map-view width of c. $25 \mathrm{~km}$ ). This model implies that segments and splays of the TKFZ and associated strands of the WNW-ESE-striking fault system die out west of Magerøya.

support sinistral strike-slip movements along segments and splays of the TKFZ and associated faults (Fig. 11A). Thus, we propose that fault segments and splays of the TKFZ and associated fault strands were dominantly reactivated as sinistral strike-slip faults, accommodating $\mathrm{km}$-scale lateral movements (Figs. 11A, F, 12E \& 13A).

By contrast, the offshore prolongation of the LVF on the eastern Finnmark Platform is offset right-laterally by c. $28 \mathrm{~km}$ (Koehl et al., 2018a). This correlation is based on zigzagging map-view geometries, comparable magnitude of normal movement (a few hundred metres to a few $\mathrm{km}$ ), and synchronous faulting ages obtained from $\mathrm{K}-\mathrm{Ar}$ dating of onshore fault-gouge (Davids et al., 2013; Torgersen et al., 2014; Koehl et al., 2018b) and syn-tectonic sedimentary wedges offshore (Koehl et al., 2018a). Dextral strike-slip movement is also supported by the Z-shape of the rhomboidal trough on bathymetry data northeast of Magerøya (Fig. 12F), which may have formed as a mini pull-apart basin along an initially sinistral strike-slip transpressional fault (e.g., the TKFZ; Rice et al., 1989; Roberts \& Olovyanishnikov, 2004) that was reactivated as a dextral strike-slip (transtensional) fault during late-post-Caledonian extension. Importantly, the LVF in Ryggefjorden aligns along a NE-SW axis with its potential continuation on the Finnmark Platform (see dotted red line in Fig. 13A), suggesting that left- and right-lateral offsets along margin-oblique segments and splays of the TKFZ and associated faults nullify/counterbalance one another, and that the TKFZ and associated fault system had a limited impact on the structuring of the margin. 
In eastern Finnmark, aeromagnetic data delineate narrow, WNW-ESE-trending, positive anomalies (Fig. 5B) similar to those reflecting dolerite dykes intruded along fault segments and splays of the TKFZ and associated faults in Magerøya (Nasuti et al., 2015a). Notably, on the Varanger Peninsula, the TKFZ and positive aeromagnetic anomalies define a narrow c. $12 \mathrm{~km}$-wide belt (Figs. 5B \& 13A; Siedlecka \& Siedlecki, 1967; Siedlecki, 1980; Nasuti et al., 2015a) that extends offshore bounding potential Late Devonian(?)-Carboniferous half-grabens (Fig. 1; Roberts et al., 2011). These anomalies splay into multiple sub-parallel anomalies arranged in a relay pattern westward onto the Nordkinn Peninsula and Magerøya, defining a much broader, c. $25 \mathrm{~km}$-wide area (same width as Magerøya). West of Magerøya these anomalies die out before reaching the Finnmark Platform (Fig. 5A, B; Gernigon et al., 2014). This suggests that the dolerite dykes and, thus, segments and splays of the TKFZ and the associated strands of the WNW-ESE-striking fault system, die out to the west in the potential '(fault-tip) process zone' of the TKFZ and associated fault system (Fig. 13B; Vermilye \& Scholz, 1988; Shipton \& Cowie, 2003; Braathen et al., 2013). The westwards increase in the number of potential splays and fault strands related to the TKFZ further supports the suggestion that the island of Magerøya is located near or at the termination of a major fault complex and fault system (Biddle \& Christie-Blick, 1985). Another argument is the counter-balancing/nullifying effect of sinistral (Fig. 11A; Andersen, 1981) and dextral (Fig. 12F) movements along brittle fault segments and splays of the TKFZ and associated faults, showing that the LVF, although offset left- and right-laterally by segments and splays of the TKFZ and associated faults, remains aligned along a NE-SW-trending axis (see dotted red line in Fig. 13A). An additional implication of the (fault-tip) process zone concept is the absence of a genetic relationship between the (subvertical) TKFZ and associated fault system and the adjacent, listric, WNW-ESE-striking segment of the Troms-Finnmark Fault Complex (Fig. 1; Koehl et al., 2018a).

\section{Interaction of the Langfjorden-Vargsundet fault with margin-oblique faults}

In Ryggefjorden and west of Magerøya (Fig. 1), segments and splays of the LVF and TKFZ interact in shaping the strandflat bathymetry, commonly merging to form bent and offset sigma-shaped troughs (Figs. 10 \& 11A). Km-scale lateral offsets $(<28 \mathrm{~km})$ and drag-related bending of segments of the LVF by segments and splays of margin-oblique faults, like the TKFZ (Figs. 10A, C \& 11A; Koehl et al., 2018a) and Akkarfjord fault (Roberts, 1971; Figs. 2 \& 9H), suggest that the latter acted as a strike-slip transfer fault during post-Caledonian extension. Moreover, these offsets indicate that faulting along margin-oblique faults persisted until marginparallel faults were fully developed (Fig. 13A).
Closely interacting ENE-WSW- and WNW-ESEstriking faults bound rhomboid-shaped structures interpreted as strike-slip duplexes (Figs. 9B, C \& 11A, B, E \& F), forming part of the Neoproterozoic fabric of the TKFZ and associated faults on Magerøya (Fig. 13A) and the Varanger Peninsula (Siedlecka \& Siedlecki, 1967; Johnson et al., 1978; Siedlecki, 1980; Herrevold et al., 2009; Roberts \& Siedlecka, 2012; Rice, 2014). Analysis of cross-cutting relationships between these two fault trends indicates that they evolved synchronously during postCaledonian extension, as they both cross-cut and offset each other (e.g., Figs. 9F, H \& 11A, E \& F) and consistently offset and/or bend NNE-SSW-striking segments of the LVF (Figs. 9H, I, 10C \& 11A, F). In addition, WNWESE- and ENE-WSW-striking faults are more abundant than NNE-SSW-striking faults on Magerøya and the Porsanger Peninsula, i.e., away from the Atlantic margin (Figs. 2 \& 3), and both display similar dominantly strike-slip (to normal oblique-slip) shear senses, which contrast with dominant dip-slip normal kinematics of NNE-SSW-striking faults (Fig. 3). Finally, K-Ar dating of ENE-WSW-striking faults in the Alta-Kvænangen tectonic window yielded latest Mesoproterozoic-midNeoproterozoic ages (Koehl et al., 2018b). Hence, the strong interaction, similarities (kinematics, geometries) and geochronology of ENE-WSW- and WNW-ESEstriking faults suggest that they might have initially formed synchronously in Neoproterozoic (Timanian?) times, potentially as conjugate (?) strike-slip fault sets and subsequently reactivated in Caledonian and Carboniferous times. A synchronous formation was also proposed for similarly striking fracture sets on the island of Seiland (Worthing, 1984) and northeastern Sørøya (Roberts, 1971).

Dominant dip-slip normal senses of shear recorded in the field suggest that NNE-SSW-striking segments of the LVF possibly formed only during post-Caledonian extension and, thus, are younger than inherited Neoproterozoic ENE-WSW- and WNW-ESE-striking faults (Figs. 10C, 11A \& 13A). This interpretation is supported by relatively sparse occurrences of NNE-SSWstriking faults in areas dominated by Neoproterozoic faults, like Magerøya and the Porsanger Peninsula (Fig. 3). Post-Caledonian faulting seemingly persisted longer along ENE-WSW- and WNW-ESE-striking faults because they both offset and/or bend NNE-SSWstriking faults. However, if interpreted as local stress perturbation in the vicinity of existing faults (Dyer, 1988), these apparent curving and offset geometries in map-view might simply suggest that NNE-SSW-striking faults formed after ENE-WSW- and WNW-ESE-striking faults, and/or that post-Caledonian faulting persisted longer along the former, which was also proposed by Hansen \& Bergh (2012) for similarly striking fault sets in Lofoten-Vesterålen.

Aeromagnetic data in Sørkjosen and Langfjorden show that the Fugløya transfer zone and its onshore extension, 
the Precambrian Bothnian-Kvænangen Fault Complex (Fig. 1), do not affect the LVF (Figs. 5A \& 8B), although they may accommodate switches of polarity between the Vestfjorden-Vanna Fault Complex and Måsøy Fault Complex farther north (Indrevær et al., 2013). Other minor, dip-slip to oblique-slip, margin-oblique, post-Caledonian faults, such as the Storhaugen fault in Altafjorden (Figs. 7G \& 12G), the WNW-ESE-striking brittle fault between Altafjorden and the Sørøy sub-basin (Figs. 7H \& 8B, C), the Markopp fault in Repparfjorden (Fig. 2; Torgersen et al., 2014) and the Kokelv Fault in Revsbotn (Figs. 13A \& Fig. 14; Gayer et al., 1985) do not seem to affect the geometry of the LVF either, which suggests that the LVF truncates margin-oblique faults, and supports the suggestion that NNE-SSW-striking faults are younger.

Based on field kinematic data, we argue that WNW-ESEoriented extension alone may explain the formation and reactivation of the various fault trends in NW Finnmark and, conceivably, farther southwest along the margin. A single extension direction is a much simpler explanation that does not require any major change in tectonic stress orientation. Stress orientation is also believed to remain constant in transpressional settings, e.g., in the West Spitsbergen Fold-and-Thrust Belt (Leever et al., 2011) and Sørvestnaget Basin (Kristensen et al., 2017), where progressive strain partitioning and decoupling allow for the formation of both margin-oblique and margin-parallel structures and fabrics, thus supporting our interpretation for post-Caledonian extension in northern Norway. Our interpretation notably contrasts with models arguing that ENE-WSW- and NNE-SSWstriking faults in Lofoten-Vesterålen formed during two discrete episodes of extension with changing stress-field conditions and varying NNW-SSE- to WNW-ESEoriented extension direction (Hansen et al., 2012; Hansen \& Bergh, 2012).

\section{Basement fabric-structure control on post- Caledonian brittle faulting}

\section{Influence of fabrics and structures in Archaean-} Palaeoproterozoic rocks

The geometry of post-Caledonian brittle faults appears to be partly controlled by preexisting Precambrian ductile fabrics and structures. For example, in Altafjorden, the major bend of the LVF coincides with the hinge zone of a NW-plunging antiform in (refolded) metavolcanic rocks of the Alta-Kvænangen and Altenes tectonic windows (Fig. 8A, B; Roberts, 1973; Bergh \& Torske, 1988; Jensen, 1996). Similarly, at the junction of Vargsundet and Repparfjorden, the LVF defines another map-view bend above the hinge of a major, NE-plunging antiform in the Repparfjord-Komagfjord tectonic window (Reitan, 1963; Pharaoh et al., 1982, 1983; Fig. 9E). These changes of attitudes of the LVF suggest a substantial influence of Precambrian ductile fabrics and structures on the architecture of post-Caledonian brittle faults in NW Finnmark (Figs. 5, 8A, B \& 9E). This is supported by brittle faults striking parallel to steeply dipping Precambrian fold limbs. For example, the Vargsundet segment of the LVF strikes parallel to the northwestern limb of the NE-plunging antiform in the Repparfjord-Komagfjord tectonic window (Fig. 9E), and the Langfjorden segment of the LVF and related NNW-dipping faults on the western side of Altafjorden (e.g., Altafjorden fault 1 and Talvik fault; Fig. 7D, E) are parallel to the northern NNW-dipping limb of the $\mathrm{NW/WNW-plunging} \mathrm{antiform} \mathrm{in} \mathrm{the} \mathrm{Alta-Kvænangen}$ tectonic window, south of Langfjorden (Fig. 8A, B; Zwaan \& Gautier, 1980; Gautier et al., 1987). In addition, the Storhaugen fault strikes parallel to the western WSW-dipping limb of the NW-plunging antiform in Altafjorden (Fig. 8A), possibly forming along steeply dipping fold limbs at depth and splaying upwards into overlying Caledonian nappe units.

Precambrian brittle fabrics also influenced the geometry of Caledonian and post-Caledonian faults. On the one hand, on Magerøya, the abundance of preexisting WNW-ESE-striking segments and splays of the TKFZ and associated fault strands may have controlled the formation of atypical, top-NE, Caledonian thrusts and related extensional brittle splay-faults within the Honningsvåg Suite (Fig. 12D). On the other hand, extension-parallel WNW-ESE-striking margin-oblique Neoproterozoic faults, like the TKFZ and Akkarfjord fault, were reactivated and accommodated $\mathrm{km}$-scale, post-Caledonian lateral offsets of margin-parallel fault complexes like the LVF (Fig. 11A).

\section{Influence of fabrics and structures in Caledonian nappe units}

Post-Caledonian extension initially localised along existing Caledonian thrusts. For instance, along the western shore of Altafjorden (Fig. 1), post-Caledonian extension utilised existing Caledonian ductile mylonitic fabrics along the Talvik fault to accommodate downnorth dip-slip normal movements (Fig. 7E). Similar controlling effects were inferred for the Kvenklubben (thrust) fault in the Repparfjord-Komagfjord tectonic window along the southeastern shore of Vargsundet (Fig. 2; Torgersen \& Viola, 2014; Torgersen et al., 2014). This low-angle SE-dipping fault acted as a brittle-ductile thrust during the Caledonian Orogeny and was later reactivated as a normal fault, possibly merging into the LVF at depth (see figure 2b in Torgersen \& Viola, 2014). Similarly, in igneous rocks of the Magerøy Nappe, gently SW-dipping Caledonian mylonitic shear zones formed as (atypical) top-NE thrusts in Silurian times, and were subsequently reactivated as low-angle dextral obliquenormal faults with down-SW movement (Figs. 11D \& 12D).

The preservation in the footwall of the LVF of c. 6-8 km-wide lenses of Kalak Nappe Complex rocks in 

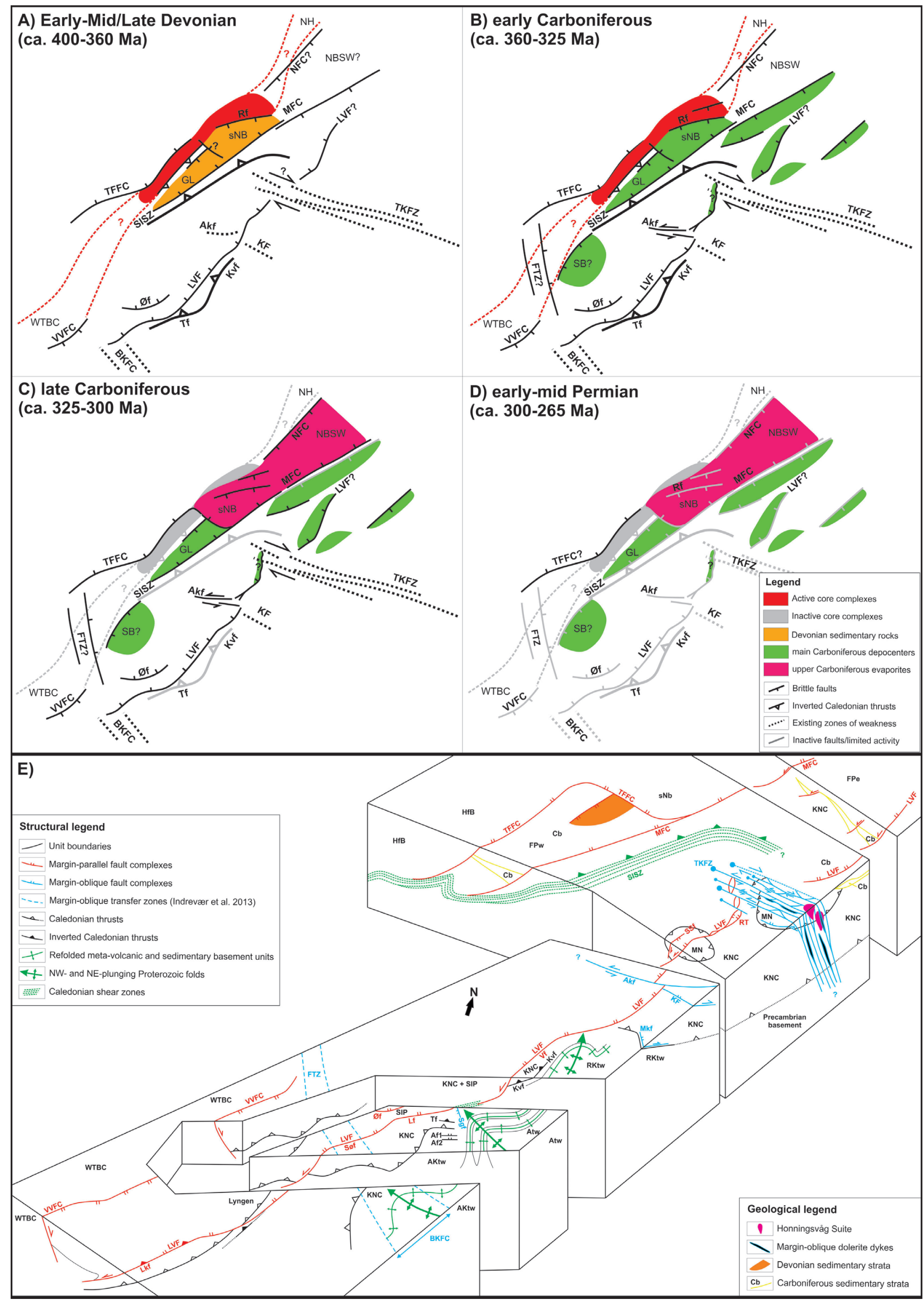
Figure 14. Map-view evolutionary model for brittle faults in NW Finnmark during late Palaeozoic post-Caledonian extension. Active brittle faults are shown in black and inactive faults in light grey. Dotted lines represent inherited Precambrian fault fabrics. (A) Initiation of the collapse of the Caledonides in the Mid to Late Devonian along inverted, low-angle, NE-SW trending Caledonian ductile thrusts such as the Kvenklubben (Kvf) and Talvik fault (Tf). Inverted low-angle Caledonian ductile thrusts quickly thinned the crust and were exhumed to shallow brittle depth and, thus, reactivated as low-angle brittle normal faults. Incremental extension led to the formation of high-angle brittle normal faults, e.g., the LVF and Øksfjorden fault, which possibly splayed upwards from Caledonian thrusts or existing fabrics and structures in Precambrian basement rocks. (B) Early Carboniferous times were marked by the deposition of thick sedimentary deposits in offshore basins on the Finnmark Platform and, potentially, in nearshore mini-basins (e.g., Ryggefjorden trough). WNW-ESE-striking faults and segments and splays of the TKFZ and associated faults were reactivated as strike-slip transfer fault offsetting and segmenting the LVF between Ryggefjorden and the Finnmark Platform. The Akkarfjord fault, a possible conjugate to the TKFZ, accommodated sinistral strike-slip displacement during post-Caledonian extension and also segmented and offset the LVF. (C) Inverted Caledonian thrusts (Tf and Kvf) became inactive and were truncated and offset due to continued extension along the LVF and related high-angle brittle normal faults. (D) Extension is believed to have come to a halt towards the end of the Carboniferous, and NW Finnmark remained tectonically quiet through Permian to Cenozoic times apart from a few minor tectonic adjustments. (E) 3D diagram of NW Finnmark and the SW Barents Sea margin showing the relationship between existing ductile fabrics and structures, and post-Caledonian brittle normal faults. Abbreviations: Af1 - Altafjorden fault 1, Af2 - Altafjorden fault 2, Akf - Akkarfjord fault, AKtw - Alta-Kvonangen tectonic window, Atw - Altenes tectonic window, BKFC - Bothnian-Kvonangen Fault Complex, $\mathrm{Cb}$ - Carboniferous, FPe - eastern Finnmark Platform, FPw - western Finnmark Platform, FTZ - Fugløya transfer zone, HfB Hammerfest Basin, KF - Kokelv Fault, KNC - Kalak Nappe Complex, Kvf - Kvenklubben fault, LVF - Langfjorden-Vargsundet fault, MFC - Måsøy Fault Complex, Mkf - Markopp fault, MN - Magerøy Nappe, RKtw - Repparfjord-Komagfjord tectonic window, RT - Ryggefjorden trough, SIP - Seiland Igneous Province, SISZ - Sørøya-Ingøya shear zone, sNb - southwesternmost Nordkapp basin, SSf - Snøfjorden-Slatten fault, Søf - Sørkjosen fault, Tf - Talvik fault, TFFC - Troms-Finnmark Fault Complex, TKFZ - Trollfjorden-Komagelva Fault Zone, VVFC - Vestfjorden-Vanna Fault Complex, WTBC - West Troms Basement Complex, Øf-Øksfjorden fault.

Vargsundet (Torgersen \& Viola, 2014; Fig. 1) and hundreds of metre-wide pods of units of the Seiland Igneous Province in Langfjorden (Marti, 2013) suggest that rocks of the Seiland Igneous Province and Kalak Nappe Complex were previously thrusted southeastwards over Precambrian basement rocks. Subsequent inversion of Caledonian thrusts (e.g., Talvik and Kvenklubben faults) and formation of high-angle post-Caledonian normal faults later contributed to juxtapose rocks of the Seiland Igneous Province against rocks of the Kalak Nappe Complex across Langfjorden (Roberts, 1973) and against Precambrian basement rocks across Vargsundet through km-scale down-NW normal movements along the LVF (Zwaan \& Roberts, 1978). This is supported by consistent down-NW normal movements along postCaledonian margin-parallel faults in these areas (Fig.
7A, B \& D-F). We propose a model in which arcuate, zigzag-shaped, post-Caledonian normal faults formed as extensional brittle splays of inverted Caledonian thrusts during the collapse of the Caledonides (Fig. 14A, B). Later on, incremental extension localised along highangle splay-faults (e.g., LVF; Fig. 14C), which, in places, eventually truncated inactive portions of low-angle Caledonian thrust faults (Fig. 14D). A similar origin was proposed for the main segment of the Mid to Late Devonian(?)-Carboniferous Måsøy Fault Complex near the coasts of Finnmark (Koehl et al., 2018a; Fig. 1), for normal faults bounding Middle Devonian collapse basins in western Norway (Wilks \& Cuthbert, 1994), and for Carboniferous faults in the North Sea (Phillips et al., 2016).

\section{Timing of brittle faulting and dolerite dykes intrusion}

Accurate timing of post-Caledonian brittle faulting along and adjacent to the LVF and TKFZ is partly constrained by geochronology (Lippard \& Prestvik, 1997; Torgersen et al., 2014; Koehl et al., 2018b) and by interpretation of syn-tectonic wedges on seismic data (Koehl et al., 2018a). On Magerøya, along segments and splays of the TKFZ and associated faults, early Carboniferous ages (337.3 $\pm 0.4 \mathrm{Ma}$ and $340 \pm 4 \mathrm{Ma}$ ) were obtained for dolerite dykes intruded along and sealing WNW-ESE-striking faults (Lippard \& Prestvik, 1997), thus providing for a minimum age estimate for post-Caledonian strike-slip reactivation of the TKFZ and associated subparallel fault strands (Fig. 14A, B). These are supported by Late Devonian (c. $370 \mathrm{Ma}){ }^{40} \mathrm{Ar}-{ }^{39} \mathrm{Ar}$ ages obtained for similar dykes on the Varanger Peninsula (Guise \& Roberts, 2002) and nearby areas of Russia (Roberts \& Onstott, 1995). However, new K-Ar dating of NW-SE trending faults in the Repparfjord-Komagfjord tectonic window, e.g., the Markopp fault (Fig. 2; Torgersen et al., 2014), and of segments and splays of the TKFZ and associated faults that are not sealed by dolerite dykes (Koehl et al., 2018b) suggest that brittle faulting may have persisted until midPermian times (Fig. 14C, D).

The LVF is correlated with nearshore and offshore basin-bounding faults on the Finnmark Platform where seismic data show that post-Caledonian brittle faulting ceased by the end of the late Carboniferous (Koehl et al., 2018a). In addition, recent K-Ar dating of segments and splays of the LVF, e.g., Talvik (Koehl et al., 2018b) and Kvenklubben faults (Torgersen et al., 2014), yielded partly younger, early Carboniferous to mid Permian ages and subsidiary Mid/Late Jurassic-Early Cretaceous ages, hence suggesting extensive widespread faulting during the collapse of the Caledonides and/or subsequent late Palaeozoic rifting, and mild reactivation during Mesozoic rifting. A formation of the LVF during latepost-orogenic collapse is also supported by arcuate fault geometries and lateral variations in fault kinematics 
(e.g., along the Øksfjorden fault) with dominant dip-slip normal shear sense near the fault's centre and gradual increase in lateral displacement toward fault tips, which is similar to what is observed for brittle faults bounding Mid Devonian collapse basins in western Norway (e.g., Séranne et al., 1989; Wilks \& Cuthbert, 1994). By comparison, in Western Troms and Lofoten-Vesterålen, $\mathrm{K}$-Ar dating of the Vestfjorden-Vanna Fault Complex (Davids et al., 2013) showed similar widespread faulting in the Late Devonian-early Permian and sporadic minor reactivation of brittle faults from the mid Permian to Early Cretaceous. In the southwest, the LVF notably correlates with the Laksvatn fault (Fig. 1), for which a Late Devonian $\mathrm{K}-\mathrm{Ar}$ age was obtained (Davids et al., 2013), thus supporting a formation of the LVF in Devonian times during late- to post-Caledonian collapse.

\section{Comparison with deep offshore basins}

Our data document the existence of nearshore sigmato rhomboid-shaped (half-)grabens bounded by zigzag-shaped normal fault segments of the LVF (e.g., Ryggefjorden trough; Fig. 10). These (half-)grabens are similar in shape and geometry to late Palaeozoic (half-)grabens imaged on seismic data on the eastern Finnmark Platform (Koehl et al., 2018a), and to the southwestern segment of the Nordkapp Basin farther offshore (Fig. 1; Gudlaugsson et al., 1998). The zigzag shape of the LVF and related onshore-nearshore brittle faults in map view, and the resulting sigma-rhomboid shape of associated (half-)grabens have arguably been shaped by existing Caledonian thrust faults (Torgersen \& Viola, 2014) and attitudes of Precambrian belts and folds at depth (Figs. 8A, B \& 9E; Reitan, 1963; Zwaan \& Gautier, 1980; Pharaoh et al., 1982, 1983; Gautier et al., 1987; Bergh \& Torske, 1988). Deeper offshore basins like the Hammerfest and Nordkapp basins, and adjacent coast-parallel faults such as the Troms-Finnmark Fault Complex and Vestfjorden-Vanna Fault Complex (Fig. $14 \mathrm{E})$, all follow existing basement trends and share the same geometric properties as the LVF (Gernigon et al., 2014; Koehl et al., 2018a). This is particularly true for the Ryggefjoren trough (Fig. 10) and the southwestern segment of the Nordkapp Basin (Fig. 1). Assuming that the LVF and related Ryggefjorden trough and southwestern segment of the Nordkapp Basin formed in the Mid to Late Devonian-early Carboniferous (Davids et al., 2013; Koehl et al., 2018a), the Ryggefjorden trough may represent an exhumed 'window' into contemporaneous faults and sedimentary strata, e.g., below upper Carboniferous-lower Permian evaporites in the Nordkapp Basin (Jensen \& Sørensen, 1992; Koyi et al., 1993; Nilsen et al., 1995).

\section{Conclusions}

1) Large ENE-WSW- and NNE-SSW-striking normal faults line up to form a major zigzag-shaped, marginparallel, NW-dipping fault complex, the LangfjordenVargsundet fault, which accommodated down-NW normal displacement in the order of hundreds of metres to a few $\mathrm{km}$. This fault complex is interpreted to have formed as an extensional brittle splay along inverted, low-angle, Caledonian brittle-ductile thrusts and, thus, represents an onshore-nearshore analogue to the Troms-Finnmark and Måsøy fault complexes formed along the inverted Sørøya-Ingøya shear zone offshore.

2) The WNW-ESE-striking margin-oblique TrollfjordenKomagelva Fault Zone corresponds to a major reactivated Neoproterozoic fault that acted as a strike-slip transfer fault separating onshore areas of NW Finnmark from the offshore eastern Finnmark Platform during post-Caledonian extension, and offsetting laterally the Langfjorden-Vargsundet fault by up to $28 \mathrm{~km}$. Post-Caledonian, km-scale sinistral and dextral offsets by fault segments and splays of the Trollfjorden-Komagelva Fault Zone nullify/counterbalance one another and the fault zone and associated fault system are interpreted to die out west of the island of Magerøya, which represents an exposed portion of the (fault-tip) process zone.

3) The WNW-ESE- to ENE-WSW-striking Akkarfjord fault may be part of an inherited Neoproterozoic strike-slip fault set that formed as a conjugate to the Trollfjorden-Komagelva Fault Zone. This fault acted as a strike-slip transfer fault during post-Caledonian extension, offsetting the Langfjorden-Vargsundet fault by c. $2 \mathrm{~km}$ left-laterally.

4) Gently NW-dipping brittle-ductile Caledonian thrust faults, and steeply NW-plunging and gently NE-plunging folds in Palaeoproterozoic basement rocks provided favourably oriented weakness zones that controlled the formation of post-Caledonian normal faults, e.g., as extensional splays of Caledonian thrusts faults and along steep limbs of Precambrian folds.

5) Major faulting events with $\mathrm{km}$-scale offsets along WNW-ESE-striking fault segments and splays of the Trollfjorden-Komagelva Fault Zone and ENEWSW- and NNE-SSW-striking fault segments of the Langfjorden-Vargsundet fault last occurred in the Late Devonian-Carboniferous. This is supported by geochronological dating of dolerite dykes and fault gouge onshore NW Finnmark, and by seismic interpretation of syn-tectonic sedimentary wedges along the offshore extension of the LangfjordenVargsundet fault on the eastern Finnmark Platform. 
6) Half-graben and graben basins bounded by the Langfjorden-Vargsundet fault in shallow-shelf areas, e.g., the Ryggefjorden trough, display trends and shapes (rhomboid- to sigma-shaped) analogous to major offshore sedimentary basins, such as the southwestern segment of the Nordkapp Basin, and to Devonian(?)-Carboniferous basins on the Finnmark Platform. The Ryggefjorden trough might therefore provide insights into the architecture of the Nordkapp Basin below thick, upper Carboniferous-lower Permian evaporites.

Acknowledgements. The present study is part of the ARCEx project (Research Centre for Arctic Petroleum Exploration) which is funded by the Research Council of Norway (grant number 228,107) together with ten academic and eight industry partners. We thank all the persons from these institutions that are involved in this project. We also express our gratitude to the Geological Survey of Norway (NGU), and in particular Odleiv Olesen, Laurent Gernigon and Aziz Nasuti for sharing and allowing the publication of aeromagnetic anomaly data and to David Roberts for constructive comments on the manuscript. We also acknowledge the help of Arnstein Osvik from the Norwegian Mapping Authority (Kartverket) for granting us access to high-resolution bathymetry and topography data and allowing the publication of parts of the data. Many thanks to Erling Rykkelid who kindly sent the first author his report on field mapping on the Porsanger Peninsula and Magerøya prior to the construction of the tunnel to Magerøya. We thank Tore Forthun, Equinor (formerly Statoil), for fruitful discussions and field collaborations. Finally, we acknowledge the review work of Prof. Emeritus David Roberts (Geological Survey of Norway), Prof. Emeritus Arild Andresen (University of Oslo) and of Dr. Thomas Berg Kristensen (Equinor), all of which helped significantly in improving the manuscript.

\section{References}

Ágústsdóttir, T., Woods, J., Greenfield, T., Green, R.G., White, R.S., Winder, T., Brandsdóttir, B., Steinthórsson, S. \& Soosalu, H. 2016: Strike-slip faulting during the 2014 Bárðarbunga-Holuhraun dike intrusion, central Iceland. Geophysical Research Letters 43, 14951503. https://doi.org/10.1002/2015GL067423.

Andersen, T.B. 1981: The structure of the Magerøy Nappe, Finnmark, North Norway. Geological Survey of Norway 363, 1-23.

Andersen, T.B. 1984: The stratigraphy of the Magerøy Supergroup, Finnmark, north Norway. Geological Survey of Norway 395, 25-37.

Andersen, T.B., Austrheim, H., Sturt, B.A., Pedersen, S. \& Kjærsud, K. 1982: Rb-Sr whole rock ages from Magerøy, North Norwegian Caledonides. Norwegian Journal of Geology 62, 79-85.

Andresen, A. \& Forslund, T. 1987: Post-Caledonian brittle faults in Troms: geometry, age and tectonic significance. The Caledonian and Related Geology of Scandinavia, Cardiff, 22-23 September, 1987.

Andresen, A., Agyei-Dwarko, N.Y., Kristoffersen, M. \& Hanken, N-M. 2014: A Timanian foreland basin setting for the late Neoproterozoic-Early Palaeozoic cover sequences (Dividal Group) of northeastern Baltica. In Corfu, F., Gasser, D. \& Chew, D.M. (eds.): New Perspectives on the Caledonides of Scandinavia and Related Areas. Geological Society of London, Special Publications 390, pp. 157-175. https://doi.org/10.1144/SP390.29.

Beckinsale, R.D., Reading, H.G. \& Rex, D.C. 1975: Potassium-argon ages for basic dykes from east Finnmark: Stratigraphical and structural implications. Scottish Journal of Geology 12, 51-65. https://doi.org/10.1144/sjg12010051.

Bergh, S.G. \& Torske, T. 1986: The Proterozoic Skoadduvarri Sandstone Formation, Alta, Northern Norway: A tectonic fan-delta complex. Sedimentary Geology 47, 1-25.

https://doi.org/10.1016/0037-0738(86)90068-0.

Bergh, S.G. \& Torske, T. 1988: Palaeovolcanology and tectonic setting of a Proterozoic metatholeiitic sequence near the Baltic Shield Margin, northern Norway. Precambrian Research 39, 227-246. https://doi.org/10.1016/0301-9268(88)90021-6.

Bergh, S.G., Eig, K., Kløvjan, O.S., Henningsen, T., Olesen, O. \& Hansen, J-A. 2007: The Lofoten-Vesterålen continental margin: a multiphase Mesozoic-Palaeogene rifted shelf as shown by offshore-onshore brittle fault-fracture analysis. Norwegian Journal of Geology 87, 29-58.

Bergh, S.G., Kullerud, K., Armitage, P.E.B., Zwaan, K.B., Corfu, F., Ravna, E.J.K. \& Myhre, P.I. 2010: Neoarchean to Svecofennian tectono-magmatic evolution of the West Troms Basement Complex, North Norway. Norwegian Journal of Geology 90, 21-48.

Bergø, E. 2016: Analyses of Paleozoic and mesozoic brittle fractures in West-Finnmark. Unpublished MSc Thesis, University of Tromsø, $128 \mathrm{pp}$.

Biddle, K.T. \& Christie-Blick, N. 1985: Glossary - Strike-slip deformation, basin formation, and sedimentation. In Biddle, K.T. \& Christie-Blick, N. (eds.): Strike-Slip Deformation, Basin Formation, and Sedimentation, Society of Economic Paleontologists and Mineralogists Special Publication 37, pp. 375-386.

https://doi.org/10.2110/pec.85.37.

Bilham, R. \& King, G. 1989: Slip Distribution on Oblique Segments of the San Andreas Fault, California: Observations and Theory. Open File Rep. U.S. Geological Survey 89-315, 80-93.

Braathen, A., Osmundsen, P-T., Nordgulen, Ø., Roberts, D. \& Meyer, G.B. 2000: Orogen-parallel extension of the Caledonides in northern Central Norway: an overview. Norwegian Journal of Geology 82, 225-241.

Braathen, A., Osmundsen, P.T., Hauso, H., Semshaug, S., Fredman, N. \& Buckley, S.J. 2013: Fault-induced deformation in poorly consolidated, siliciclastic growth basin: A study from the Devonian in Norway. Tectonophysics 586, 112-129. https://doi.org/10.1016/j.tecto.2012.11.008.

Breivik, A.J., Gudlaugsson, S.T. \& Faleide, J.I. 1995: Ottar Basin, SW Barents Sea: a major Upper Palaeozoic rift basin containing large volumes of deeply buried salt. Basin Research 7, 299-312. https://doi.org/10.1111/j.1365-2117.1995.tb00119.x.

Buck, W.R., Einarsson, P. \& Brandsdóttir, B. 2006: Tectonic stress and magma chamber size as controls on dike propagation: Constraints from the 1975-1984 Krafla rifting episode. Journal of Geophysical Research 111. https://doi.org/10.1029/2005JB003879.

Bylund, G. 1994: Palaeomagnetism of the Late Precambrian Vadsø and Barents Sea Groups, Varanger Peninsula, Norway. Precambrian Research 69, 81-93. https://doi.org/10.1016/0301-9268(94)90080-9.

Bøe, P. \& Gautier, A.M. 1978: Precambrian primary volcanic structures in the Alta-Kvænangen tectonic window, northern Norway. Norwegian Journal of Geology 58, 113-119.

Chauvet, A. \& Séranne, M. 1994: Extension-parallel folding in the Scandinavian Caledonides: implications for late-orogenic processes. Tectonophysics 238, 31-54. https://doi.org/10.1016/0040-1951(94)90048-5.

Christie-Blick, N. \& Biddle, K.T. 1985: Deformation and basin formation along strike-slip faults. In Biddle, K.T. \& ChristieBlick, N. (eds.): Strike-Slip Deformation, Basin Formation, and Sedimentation, Society of Economic Paleontologists and Mineralogists Special Publication 37, pp. 1-34. https://doi.org/10.2110/pec.85.37.0001.

Cianfarra, P. \& Salvini, F. 2015: Lineament Domain of Regional StrikeSlip Corridor: Insight from the Neogene Transtentional De Geer Transform Fault in NW Spitsbergen. Pure and Applied Geophysics 172, 1185-1201. https://doi.org/10.1007/s00024-014-0869-9. 
Corfu, F., Torsvik, T.H., Andersen, T.B., Ashwal, L.D., Ramsay, D.M. \& Roberts, R.J. 2006: Early Silurian mafic-ultramafic and granitic plutonism in contemporaneous flysch, Magerøy, northern Norway: $\mathrm{U}-\mathrm{Pb}$ ages and regional significance. Journal of the Geological Society of London 163, 291-301.

https://doi.org/10.1144/0016-764905-014.

Corfu, F., Andersen, T.B. \& Gasser, D. 2014: The Scandinavian Caledonides: main features, conceptual advances and critical questions. In Corfu, F., Gasser, D. \& Chew, D.M. (eds.): New Perspectives on the Caledonides of Scandinavia and Related Areas, Geological Society of London Special Publications 390, pp. 9-43. https://doi.org/10.1144/SP390.25.

Davids, C., Wemmer, K., Zwingmann, H., Kohlmann, F., Jacobs, J. \& Bergh, S.G. 2013: K-Ar illite and apatite fission track constraints on brittle faulting and the evolution of the northern Norwegian passive margin. Tectonophysics 608, 196-211. https://doi.org/10.1016/j.tecto.2013.09.035.

Dengo, C.A. \& Røssland, K.G. 1992: Extensional tectonic history of the western Barents Sea. In Larsen, R.M., Brekke, H., Larsen, B.T. \& Talleraas, F. (eds.): Structural and Tectonic Modelling and its Apllication to Petroleum Geology, Norwegian Petroleum Society Special Publication 1, pp. 91-107. https://doi.org/10.1016/B978-0-444-88607-1.50011-5.

Doré, A.G., Lundin, E.R., Jensen, L.N., Birkeland, Ø., Eliassen, P.E. \& Fichler, C. 1999: Principal tectonic events in the evolution of the northwest European Atlantic margin. In Fleet, A.J. \& Boldy, S.A.R. (eds.): Petroleum Geology of Northwest Europe: Proceedings of the 5th Conference, Petroleum Geology, Geological Society, London, pp 41-61. https://doi.org/10.1144/0050041.

Dyer, R. 1988: Using Joint Interactions to Estimate Paleostress Ratios. Journal of Structural Geology 10, 685-699. https://doi.org/10.1016/0191-8141(88)90076-4.

Eig, K. 2008: Onshore and offshore tectonic evolution of the Lofoten passive margin, North Norway. PhD thesis, University of Tromsø, $256 \mathrm{pp}$.

Eig, K. \& Bergh, S.G. 2011: Late Cretaceous-Cenozoic fracturing in Lofoten, North Norway: Tectonic significance, fracture mechanisms and controlling factors. Tectonophysics 499, 190-215. https://doi.org/10.1016/j.tecto.2010.12.002.

Elvevold, S., Reginiussen, H., Krogh, E.J. \& Bjørklund, F. 1994: Reworking of deep-seated gabbros and associated contact metamorphosed paragneisses in the south-eastern part of the Seiland Igneous Province, northern Norway. Journal of Metamorphic Geology 12, 539-556.

https://doi.org/10.1111/j.1525-1314.1994.tb00041.x.

Fairhead, J.D., Salem, A., Williams, S. \& Samson, E. 2008: Magnetic interpretation made easy: The Tilt-Depth-Dip- $\Delta \mathrm{K}$ method. SEG Technical Program Expanded Abstracts 2008, p. 779-783. https://doi.org/10.1190/1.3063761.

Faleide, J.I., Vågnes, E. \& Gudlaugsson, S.T. 1993: Late MesozoicCenozoic evolution of the south-western Barents Sea in a regional rift-shear tectonic setting. Marine and Petroleum Geology 10, 186214. https://doi.org/10.1016/0264-8172(93)90104-Z.

Faleide, J.I., Tsikalas, F., Breivik, A.J., Mjelde, R., Ritzmann, O., Engen, Ø., Wilson, J. \& Eldholm, O. 2008: Structure and evolution of the continental margin off Norway and the Barents Sea. Episodes 31, 82-91.

Forslund, T. 1988: Post-Kaledonske forkastninger I Vest-Troms, med vekt på Kvaløyslettaforkastningen, Kvaløya. MSc Thesis, University of Tromsø, 173 pp.

Gabrielsen, R.H. 1984: Long-lived fault zones and their influence on the tectonic development of the southwestern Barents Sea. Journal of the Geological Society, London 141, 651-662. https://doi.org/10.1144/gsjgs.141.4.0651.

Gabrielsen, R.H. \& Færseth, R.B. 1989: The inner shelf of North Cape, Norway and its implications for the Barents Shelf-Finnmark Caledonide boundary. A comment. Norwegian Journal of Geology $69,57-62$.
Gabrielsen, R.H. \& Koestler, A.G. 1987: Description and structural implications of fractures in late Jurassic sandstones of the Troll Field, northern North Sea. Norwegian Journal of Geology 67, 371381.

Gabrielsen, R.H., Færseth, R.B., Jensen, L.N., Kalheim, J.E. \& Riis, F. 1990: Structural elements of the Norwegian continental shelf, Part I: The Barents Sea Region. Norwegian Petroleum Directorate Bulletin 6, 1-33.

Gabrielsen, R.H., Braathen, A., Dehls, J. \& Roberts, D. 2002: Tectonic lineaments of Norway. Norwegian Journal of Geology 82, 153-174.

Gautier, A.M., Zwaan, K.B., Bakke, I., Lundahl, I., Ryghaug, P. \& Vik, E. 1987: Kvænangen bedrock map 1734 1, scale 1:50,000, Geological Survey of Norway.

Gayer, R.A., Hayes, S.J. \& Rice, A.H.N. 1985: The structural development of the Kalak Nappe Complex of Eastern and Central Porsangerhalvøya, Finnmark, Norway. Geological Survey of Norway Bulletin 400, 67-87.

Gayer, R.A., Rice, A.H.N., Roberts, D., Townsend, C. \& Welbon, A. 1987: Restoration of the Caledonian Baltoscandian margin from balanced cross-secyions: the problem of excess continental crust. Transactions of the Royal Society of Edinburgh: Earth Sciences 78, 197-217. https://doi.org/10.1017/S026359330001110X.

Gernigon, L., Brönner, M., Roberts, D., Olesen, O., Nasuti, A. \& Yamasaki, T. 2014: Crustal and basin evolution of the southwestern Barents Sea: From Caledonian orogeny to continental breakup. Tectonics 33, 347-373. https://doi.org/10.1002/2013TC003439.

Goldstein, A. \& Marshak, S. 1988: Analysis of fracture array geometry. In Marshak, S. \& Mitra, G. (eds.): Basic Methods of Structural Geology, Prentice Hall, Englewood Cliffs, New Jersey, pp. 249-267.

Gudlaugsson, S.T., Faleide, J.I., Johansen, S.E. \& Breivik, A.J. 1998: Late Palaeozoic structural development of the South-western Barents Sea. Marine and Petroleum Geology 15, 73-102. https://doi.org/10.1016/S0264-8172(97)00048-2.

Guise, P.G. \& Roberts, D. 2002: Devonian ages from ${ }^{40} \mathrm{Ar} /{ }^{39} \mathrm{Ar}$ dating of plagioclase in dolerite dykes, eastern Varanger Peninsula, North Norway. Geological Survey of Norway 440, 27-37.

Hames, W.E. \& Andresen, A. 1996: Timing of Paleozoic orogeny and extension in the continental shelf of north-central Norway as indicated by laser ${ }^{40} \mathrm{Ar} /{ }^{39} \mathrm{Ar}$ muscovite dating. Geology 24, 10051008 .

https://doi.org/10.1130/0091-7613(1996)024<1005:TOPOAE>2.3.CO;2.

Hansen, J-A. \& Bergh, S.G. 2012: Origin and reactivation of fracture systems adjacent to the Mid-Norwegian continental margin on Hamarøya, North Norway: use of digital geological mapping and morphotectonic lineament analysis. Norwegian Journal of Geology 92, 391-403.

Hansen, J-A., Bergh, S.G. \& Henningsen, T. 2012: Mesozoic rifting and basin evolution on the Lofoten and Vesterålen Margin, NorthNorway; time constraints and regional implications. Norwegian Journal of Geology 91, 203-228.

Harding, T.P. \& Lowell, J.D. 1979: Structural Styles, Their PlateTectonic Habitats, and Hydrocarbon Traps in Petroleum Provinces. American Association of Petroleum Geologists Bulletin 63, 10161058 . https://doi.org/10.1306/2F9184B4-16CE-11D7-8645000102C1865D.

Hayes, S.J. 1980: The Caledonian geology of NE Porsangerhalvøya, Finnmark, North Norway. Unpublished PhD thesis, University of Wales.

Henderson, I.H.C., Viola, G. \& Nasuti, A. 2015: A new tectonic model for the Palaeoproterozoic Kautokeino Greenstone Belt, northern Norway, based on high-resolution airborne magnetic data and field structural analysis and implications for mineral potential. Norwegian Journal of Geology 95, 1-26. https://doi.org/10.17850/njg95-3-05.

Henstra, G.A. \& Rotevatn, A. 2014: Nature of Palaeozoic extension in Lofoten, north Norwegian Continental Shelf: insights from 3-D seismic analysis of a Cordilleran-style metamorphic core complex. Terra Nova 26, 247-252. https://doi.org/10.1111/ter.12098. 
Herrevold, T., Gabrielsen, R.H. \& Roberts, D. 2009: Structural geology of the southeastern part of the Trollfjorden-Komagelva Fault Zone, Varanger Peninsula, Finnmark, North Norway. Norwegian Journal of Geology 89, 305-325.

Hjartardóttir, Á.R., Einarsson, P., Bramham, E. \& Wright, T.J. 2012: The Krafla fissure swarm, Iceland, and its formation by rifting events. Bulletin of Volcanology 74, 2139-2153. https://doi.org/10.1007/s00445-012-0659-0.

Indrevær, K. \& Bergh, S.G. 2014: Linking onshore-offshore basement rock architecture and brittle faults on the submerged strandflat along the SW Barents Sea margin, using high-resolution ( 5 x $5 \mathrm{~m}$ ) bathymetry data. Norwegian Journal of Geology 94, 1-34.

Indrevær, K., Bergh, S.G., Koehl, J-B., Hansen, J-A., Schermer, E.R. \& Ingebrigtsen, A. 2013: Post-Caledonian brittle fault zones on the hyperextended SW Barents Sea margin: New insights into onshore and offshore margin architecture. Norwegian Journal of Geology 93, 167-188.

Jansen, Ø, Akselsen, J. \& Roberts, D. 2012: Berggrunnsgeologisk kart Hammerfest 1936 III, scale 1:50,000, Geological Survey of Norway.

Jensen, L.N. \& Sørensen, K. 1992: Tectonic framework and halokinesis of the Nordkapp Basin, Barents Sea. In Larsen, R.M., Brekke, H., Larsen, B.T. \& Talleraas, E. (eds.): Structural and Tectonic Modelling and its Application to Petroleum Geology, Norwegian Petroleum Society Special Publications 1, pp. 109-120.

https://doi.org/10.1016/B978-0-444-88607-1.50012-7.

Jensen, P.A. 1996: The Altenes and Repparfjord tectonic windows, Finnmark, northern Norway: Remains of a Palaeopreterozoic Andean-type plate margin at the rim of the Baltic Shield. Unpublished PhD Thesis, University of Tromsø, $120 \mathrm{pp}$.

Johnson, H.D., Levell, B.K. \& Siedlecki, S. 1978: Precambrian sedimentary rocks in East Finnmark, north Norway and their relationship to the Trollfjord-Komagelv fault. Journal of the Geological Society of London 132, 517-533. https://doi.org/10.1144/gsjgs.135.5.0517.

Karpuz, M.R., Roberts, D., Olesen, O., Gabrielsen, R.H. \& Herrevold, T. 1993: Application of multiple data sets to structural studies on Varanger Penisula, Northern Norway. International Journal of Remote Sensing 14, 979-1003. https://doi.org/10.1080/01431169308904390.

Karpuz, M.R., Roberts, D., Moralev, V.M. \& Terekhov, E. 1995: Regional lineaments of eastern Finnmark, Norway, and the western Kola Peninsula, Russia. Geological Survey of Norway Special Publication 7, 121-135.

Kirkland, C.L., Daly, J.S. \& Whitehouse, M.J. 2005: Early Silurian magmatism and the Scandian evolution of the Kalak Nappe Complex, Finnmark, Arctic Norway. Journal of the Geological Society of London 162, 985-1003.

https://doi.org/10.1144/0016-764904-124.

Kirkland, C.L., Daly, J.S., Eide, E.A. \& Whitehouse, M.J. 2006: The structure and timing of lateral escape during the Scandian Orogeny: A combined strain and geochronological investigation in Finnmark, Arctic Norwegian Caledonides, Tectonophysics 425, 156-189. https://doi.org/10.1016/j.tecto.2006.08.001.

Kirkland, C.L., Daly, J.S. \& Whitehouse, M.J. 2007: Provenance and Terrane Evolution of the Kalak Nappe Complex, Norwegian Caledonides: Implications for Neoproterozoic Paleogeography and Tectonics. The Journal of Geology 115, 21-41. https://doi.org/10.1086/509247.

Kirkland, C.L., Daly, J.S. \& Whitehouse, M.J. 2008: Basement-cover relationships of the Kalak Nappe Complex, Arctic Norwegian Caledonides and constraints on Neoproterozoic terrane assembly in the North Atlantic region. Precambrian Research 160, 245-276. https://doi.org/10.1016/j.precamres.2007.07.006.

Klein, A.C. \& Steltenpohl, M.G. 1999: Basement-cover relations and late- to post-Caledonian extension in the Leknes group, westcentral Vestvågøy, Lofoten, north Norway. Norwegian Journal of Geology 79, 19-31. https://doi.org/10.1080/002919699433889.
Klein, A.C., Steltenpohl, M.G., Hames, W.E. \& Andresen, A. 1999: Ductile and brittle extension in the southern Lofoten archipelago, north Norway: implications for differences in tectonic style along an ancient collisional margin. American Journal of Science 299, 69-89. https://doi.org/10.2475/ajs.299.1.69.

Koehl, J-B.P., Bergh, S.G., Henningsen, T. \& Faleide, J.I. 2018a: Middle to Late Devonian-Carboniferous collapse basins on the Finnmark Platform and in the southwesternmost Nordkapp basin, SW Barents Sea. Solid Earth 9, 341-372. https://doi.org/10.5194/se-9-341-2018.

Koehl, J-B.P., Bergh, S.G. \& Wemmer, K. 2018b: Neoproterozoic and post-Caledonian exhumation and shallow faulting in NW Finnmark from K-Ar dating and p/T analysis of fault-rocks. Solid Earth 9, 923-951. https://doi.org/10.5194/se-2018-16.

Koyi, H., Talbot, C.J. \& Tørudbakken, B.O. 1993: Salt diapirs of the southwest Nordkapp Basin analogue modelling. Tectonophysics 228, 167-187. https://doi.org/10.1016/0040-1951(93)90339-L.

Kristensen, T.B., Rotevatn, A., Marvik, M., Henstra, G.A., Gawthorpe, R.L. \& Ravnås, R. 2017: Structural evolution of sheared margin basins: the role of strain partitioning. Sør vestnaget Basin, Norwegian Barents Sea. Basin Research 30, 1-23. https://doi.org/10.1111/bre.12253.

Kvassnes, A., Strand, A., Moen-Eikeland, H. \& Pedersen, R. 2004: The Lyngen Gabbro: the lower crust of an Ordovician Incipient Arc. Contributions to Mineralogy and Petrology 148, 358-379. https://doi.org/10.1007/s00410-004-0609-8.

Larssen, G.B. Elvebakk, G., Henriksen, S.E., Nilsson, I., Samuelsberg, T.J., Svånå, T.A., Stemmerik, L. \& Worsley, D. 2002: Upper Palaeozoic lithostratigraphy of the Southern Norwegian Barents Sea. Norwegian Petroleum Directorate Bulletin 9, 1-76.

Lea, H. 2016: Analysis of Late Paleozoic-Mesozoic brittle faults and fractures in West-Finnmark: geometry, kinematics, fault rocks and the relationship to offshore structures on the Finnmark Platform in the SW Barents Sea. Unpublished MSc Thesis, University of Tromsø, $129 \mathrm{pp}$.

Leever, K.A., Gabrielsen, R.H., Faleide, J.I. \& Braathen A. 2011: A transpressional origin for the West Spitsbergen fold-and-thrust belt: Insight from analog modelling. Tectonics 30, 1-24. https://doi.org/10.1029/2010TC002753.

Lindahl, I., Stevens, B.J. \& Zwaan, K.B. 2005: The geology of the Váddás area, Troms: a key to our understanding of the Upper Allochthon in the Caledonides of northern Norway. Geological Survey of Norway Bulletin 445, 5-43.

Lippard, S.J. \& Prestvik, T. 1997: Carboniferous dolerite dykes on Magerøy: new age determination and tectonic significance. Norwegian Journal of Geology 77, 159-163.

Lippard, S.J. \& Roberts, D. 1987: Fault systems in Caledonian Finnmark and the southern Barents Sea. Geological Survey of Norway Bulletin 410, 55-64.

Marti, S. 2013: The Kalak Nappe Complex in Northern Norway: unraveling the tectonic evolution using quartz fabrics. Unpublished MSc Thesis, University of Basel, 135 pp.

Mattingsdal, R., Høy, T., Simonstad, E. \& Brekke, H. 2015: An updated map of structural elements in the southern Barents Sea, Norwegian Petroleum Directorate.

Melezhik, V.A., Bingen, B., Sandstad, J.S., Pokrovsky, B.G., Solli, A. \& Fallick, A. 2015: Sedimentary-volcanic successions of the Alta-Kvænangen Tectonic Window in the northern Norwegian Caledonides: Multiple constraints on deposition and correlation with complexes on the Fennoscandian Shield. Norwegian Journal of Geology 95, 245-284. https://doi.org/10.17850/njg95-3-01.

Nasuti, A., Roberts, D. \& Gernigon, L. 2015a: Multiphase mafic dykes in the Caledonides of northern Finnmark revealed by a new highresolution aeromagnetic dataset. Norwegian Journal of Geology 95, 251-263. https://doi.org/10.17850/njg95-3-02.

Nasuti, A., Roberts, D., Dumais, M-A., Ofstad, F., Hyvönen, E., Stampolidis, A. \& Rodionov, A. 2015b: New high-resolution 
aeromagnetic and radiometric surveys in Finnmark and North Troms: linking anomaly patterns to bedrock geology and structure. Norwegian Journal of Geology 95, 217-244.

https://doi.org/10.17850/njg95-3-10.

Nilsen, K.T., Vendeville, B.C. \& Johansen, J-T. 1995: Influence of Regional Tectonics on Halokinesis in the Nordkapp Basin, Barents Sea. In Jackson, M.P.A., Roberts, D.G. \& Snelson, S. (eds.): Salt tectonics a global perspective, American Association of Petroleum Geologists Memoir 65, pp. 413-436.

Olesen, O., Roberts, D., Henkel, H., Lile, O.B. \& Torsvik, T.H. 1990: Aeromagnetic and gravimetric interpretation of regional structural features in the Caledonides of West Finnmark and North Troms, northern Norway. Geological Survey of Norway Bulletin 419, 1-24.

Olesen, O., Torsvik, T.H., Tveten, E. \& Zwaan, K.B. 1993: The LofotenLopphavet Project - an integrated approach to the study of a passive continental margin, Summary report. Geological Survey of Norway, 54 pp.

Olesen, O., Torsvik, T.H., Tveten, E., Zwaan, K.B., Løseth, H. \& Henningsen, T. 1997: Basement structure of the continental margin in the Lofoten-Lopphavet area, northern Norway: constraints from potential field data, on-land structural mapping and palaeomagnetic data. Norwegian Journal of Geology 77, 15-30.

Osmundsen, P-T. \& Andersen, T.B. 2001: The middle Devonian basins of western Norway: sedimentary response to large-scale transtensional tectonics. Tectonophysics 332, 51-68. https://doi.org/10.1016/S0040-1951(00)00249-3.

Osmundsen, P.T., Braathen, A., Sommaruga, A., Skilbrei, J.R., Nordgulen, Ø., Roberts, D., Andersen, T.B., Olesen, O. \& Mosar, J. 2005: Metamorphic core complexes and gneiss-cored culminations along the Mid-Norwegian margin: an overview and some current ideas. In Wandaas, B., Gradstein, F. et al. (eds.): Onshore-offshore relations on the Mid-Norwegian margin, Norwegian Petroleum Society, Special Publications 12, pp. 29-41. https://doi.org/10.1016/S0928-8937(05)80042-6.

Ottesen, D., Stokes, C.R., Rise, L. \& Olsen, L. 2008: Ice-sheet dynamics and ice streaming along the coastal parts of northern Norway. Quaternary Science Reviews 27, 922-940.

Passe, C.R. 1978: The structural geology of east Snøfjord, Finnmark, North Norway. Unpublished PhD thesis, University of Wales.

Pastore, Z., Fichler, C. \& McEnroe, S.A. 2016: The deep crustal structure of the mafic-ultramafic Seiland Igneous Province of Norway from 3-D gravity modelling and geological implications. Geophysical Journal International 207, 1653-1666. https://doi.org/10.1093/gji/ggw362.

Peacock, D.C.P., Nixon, C.W., Rotevatn, A., Sanderson, D.J. \& Zuluaga, L.F. 2016: Glossary of fault and other fracture networks. Journal of Structural Geology 92, 12-29. https://doi.org/10.1016/j.jsg.2016.09.008.

Pharaoh, T.C., Macintyre, R.M. \& Ramsay, D.M. 1982: K-Ar age determinations on the Raipas suite in the Komagfjord Window, northern Norway. Norwegian Journal of Geology 62, 51-57.

Pharaoh, T.C., Ramsay, D.M. \& Jansen, Ø. 1983: Stratigraphy and Structure of the Northern Part of the Repparfjord-Komagfjord Window, Finnmark, Northern Norway. Geological Survey of Norway 377, 1-45.

Phillips, T., Jackson, C.A-L., Bell, R.E., Duffy, O.B. \& Fossen, H. 2016: Reactivation of intrabasement structures during rifting: A case study from offshore southern Norway. Journal of Structural Geology 91, 54-73. https://doi.org/10.1016/j.jsg.2016.08.008.

Rafaelsen, B., Elvebakk, G., Andreassen, K., Stemmerik, L., Colpaert, A. \& Samuelsberg, T.J. 2008: From detached to attached carbonate buildup complexes - 3D seismic data from the Upper Palaeozoic, Finnmark Platform, southwestern Barents Sea. Sedimentary Geology 206, 17-32. https://doi.org/10.1016/j.sedgeo.2008.03.001.

Ramberg, I.B., Bryhni, I., Nøttvedt, A. \& Rangnes, K. 2008: The making of a land. Geology of Norway. The Norwegian geological Association, Oslo, $624 \mathrm{pp}$.
Ramsay, D.M., Sturt, B.A. \& Andersen, T B. 1979: The sub-Caledonian unconformity on Hjelmsøy - New Evidence of Primary Basement/ Cover Relations in the Finnmarkian Nappe Sequence. Geological Survey of Norway Bulletin 351, 1-12.

Ramsay, D.M., Sturt, B.A., Jansen, Ø., Andersen, T.B. \& Sinha-Roy, S. 1985: The tectonostratigraphy of western Porsangerhalvøya, Finnmark, north Norway. In Gee, D.G. \& Sturt, B.A. (eds.): The Caledonide Orogen-Scandinavia and Related Areas, John Wiley \& Sons Ltd, London, pp. 1-18.

Reitan, P.H. 1963: The geology of the Komagfjord tectonic window of the Raipas suite, Finnmark, Norway. Geological Survey of Norway $221,1-71$.

Rice, A.H.N. 1982: The geology of the Kalak Nappe between Revsbotn and Repparfjord, Finnmark, North Norway. Unpublished PhD thesis, University of Wales.

Rice, A.H.N. 2014: Restoration of the External Caledonides, Finnmark, North Norway. In Corfu, F., Gasser, D. \& Chew, D.M. (eds.): New Perspectives on the Caledonides of Scandinavia and Related Areas, Geological Society of London, Special Publications 390, pp. 271299. https://doi.org/10.1144/SP390.18.

Rice, A.H.N., Gayer, R.A., Robinson, D. \& Bevins, R.E. 1989: Strikeslip restoration of the Barents Sea Caledonides Terrane, Finnmark, North Norway. Tectonics 8, 247-264. https://doi.org/10.1029/TC008i002p00247.

Rice, A.H.N., Ntaflos, T., Gayer, R.A. \& Beckinsale, R.D. 2004: Metadolerite geochronology and dolerite geochemistry from East Finnmark, northern Scandinavian Caledonides. Geological Magazine 141,301-318. https://doi.org/10.1017/S001675680300788X.

Roberts, D. 1971: Patterns of folding and fracturing in north-east Sørøy. Geological Survey of Norway 269, 89-95.

Roberts, D. 1972: Tectonic deformation in the Barents Sea region of Varanger Peninsula, Finnmark. Geological Survey of Norway 282, $1-39$.

Roberts, D. 1973: Geologisk kart over Norge, berggrunnskart. Hammerfest, scale 1:250,000, Geological Survey of Norway.

Roberts, D. 1987: Honningsvåg berggrunnsgeologisk kart 2136 4, scale 1:50,000, Geological Survey of Norway.

Roberts, D. 1995: Principal features of the structural geology of Rybachi and Sredni Peninsulas, Northwest Russia, and come comparisons with Varanger Peninsula, North Norway. Geological Survey of Norway Special Publication 7, 247-258.

Roberts, D. 1998: Berggrunnskart Honningsvåg - Geologisk kart over Norge, scale 1:250,000, Geological Survey of Norway.

Roberts, D. \& Karpuz, M.R. 1995: Structural features of the Rybachi and Sredni Peninsulas Northwest Russia, as interpreted from Landsat-TM imagery. Geological Survey of Norway Special Publication 7, 145-150.

Roberts, D. \& Lippard, S.J. 2005: Inferred Mesozoic faulting in Finnmark: current status and offshore links. Norges geologiske undersøkelse Bulletin 443, 55-60.

Roberts, D. \& Olovyanishnikov, V. 2004: Structural and tectonic development of the Timanide orogen. In Gee, D.G. \& Pease, V. (eds.): The Neoproterozoic Timanide Orogen of Eastern Baltica, Geological Society of London, Memoirs 30, pp. 47-57. https://doi.org/10.1144/GSL.MEM.2004.030.01.05.

Roberts, D. \& Onstott, T.C. 1995: 40Ar/39Ar laser microprobe analyses and geochemistry of dolerite dykes from the Rybachi and Sredni Peninsulas, NW Kola, Russia. Geological Survey of Norway Special Publication 7, 307-314.

Roberts, D. \& Siedlecka, A. 2012: Provenance and sediment routing of Neoproterozoic formations on the Varanger, Nordkinn, Rybachi and Sredni peninsulas, North Norway and Northwest Russia: a review. Geological Survey of Norway Bulletin 452, 1-19.

Roberts, D. \& Williams, G.D. 2013: Berggrunnskart Kjøllefjord 2236-4, scale 1:50,000, Geological Survey of Norway. 
Roberts, D., Mitchell, J.G. \& Andersen, T.B. 1991: A post-Caledonian dyke from Magerøy North Norway: age and geochemistry. Norwegian Journal of Geology 71, 289-294.

Roberts, D., Chand, S. \& Rise, L. 2011: A half-graben of inferred Late Palaeozoic age in outer Varangerfjorden, Finnmark: evidence from seismic reflection profiles and multibeam bathymetry. Norwegian Journal of Geology 91, 191-200.

Roberts, R.J., Corfu, F., Torsvik, T.H., Ashwal, L.D. \& Ramsay, D.M. 2006: Short-lived mafic magmatism at 560-570 Ma in the northern Norwegian Caledonides: U-Pb zircon ages from the Seiland Igneous Province. Geological Magazine 143, 887-903. https://doi.org/10.1017/S0016756806002512.

Roberts, R.J., Corfu, F., Torsvik, T.H., Hetherington, C.J. \& Ashwal, L.D. 2010: Age of alkaline rocks in the Seiland Igneous Province, Northern Norway. Journal of the Geological Society of London 167, 71-81. https://doi.org/10.1144/0016-76492009-014.

Robins, B. 1990a: Nordkapp berggrunnskart 2037 2, scale 1:50,000, Geological Survey of Norway.

Robins, B. 1990b: Skarsvåg berggrunnsgeologisk kart 2137 3, scale 1:50,000, Geological Survey of Norway.

Robins, B. 1998: The mode of emplacement of the Honningsvåg Intrusive Suite, Magerøya, northern Norway. Geological Magazine 135, 231-244. https://doi.org/10.1017/S0016756898008395.

Robins, B. \& Gardner, P.M. 1975: The magmatic evolution of the Seiland Province, and Caledonian plate boundary in northern Norway. Earth and Planetary Science Letters 26, 167-178. https://doi.org/10.1016/0012-821X(75)90084-9.

Robins, B., Haukvik, L. \& Jansen, S. 1987: The organization and internal structure of cyclic units in the Honningsvåg Intrusive Suite, North Norway: implications for intrusive mechanisms, doublediffusive convection and pore-magma infiltration. In Parsons, I. (ed.): Origins of Igneous Layering, Dordrecht: D. Reidel Publishing Company, pp. 287-312. https://doi.org/10.1007/978-94-017-2509-5_9.

Rykkelid, E. 1992: E69 “FATIMA” - Geologisk undersøkelse av tunnel under Magerøysundet. Veglaboratoriet, Statens Vegvesen.

Samuelsberg, T.J., Elvebakk, G. \& Stemmrik, L. 2003: Late Paleozoic evolution of the Finnmark Platform, southern Norwegian Barents Sea. Norwegian Journal of Geology 83, 351-362.

Schiffer, W.J. 2017: Structural and Metamorphic Implications of the Final Emplacement of the Lyngen Nappe. Unpublished MSc Thesis, University of Tromsø, $117 \mathrm{pp}$. https://doi.org/10.1130/abs/2017AM-301444.

Segall, P. \& Pollard, D.D. 1980: mechanics of Discontinuous Faults. Journal of Geophysical Research 85, 4337-4350. https://doi.org/10.1029/JB085iB08p04337.

Séranne, M., Chauvet, A., Seguret, M. \& Brunel, M. 1989: Tectonics of the Devonian collapse-basins of western Norway. Bulletin de la Société Géologique de France 8, 489-499.

Shipton, Z.K. \& Cowie, P.A. 2003: A conceptual model for the origin of fault damage zone structures in high-porosity sandstones. Journal of Structural Geology 25, 333-344. https://doi.org/10.1016/S0191-8141(02)00037-8.

Siedlecka, A. 1975: Late Precambrian Stratigraphy and Structure of the North-Eastern Margin of the Fennoscandian Shield (East Finnmark - Timan Region). Geological Survey of Norway 316, 313-348.

Siedlecka, A. 1985: Development of the Upper Proterozoic sedimentary basins of the Varanger Peninsula, east Finnmark, North Norway. Geological Survey of Finland Bulletin 331, 175-185.

Siedlecka, A. \& Siedlecki, S. 1967: Some new aspects of the geology of Varanger peninsula (Northern Norway). Norges geologiske undersøkelse 247, 288-306.

Siedlecka, A., Roberts, D., Nystuen, J.P. \& Olovyanishnikov, V.G. 2004: Northeastern and northwestern margins of Baltica in Neoproterozoic time: evidence from the Timanian and Caledonian Orogens. Geological Society of London, Memoirs 30, 169-190. https://doi.org/10.1144/GSL.MEM.2004.030.01.15.
Siedlecki, S. 1980: Geologisk kart over Norge, berggrunnskart Vadsø, scale 1:250,000, Geological Survey of Norway.

Slagstad, D. 1995: Lyngen Magmatic Complex Rypdalen Shear Zone: magmatic and structural evolution. Geonytt 22, 22-67.

Steltenpohl, M.G., Hames, W.E. \& Andresen, A. 2004: The Silurian to Permian history of a metamorphic core complex in Lofoten, northern Scandinavian Caledonides. Tectonics 23, 1-23. https://doi.org/10.1029/2003TC001522.

Steltenpohl, M.G., Moecher, D., Andresen, A., Ball, J., Mager, S. \& Hames, W.E. 2011: The Eidsfjord shear zone, Lofoten-Vesterålen, north Norway: An Early Devonian, paleoseismogenic low-angle normal fault. Journal of Structural Geology 33, 1023-1043. https://doi.org/10.1016/j.jsg.2011.01.017.

Torgersen, E. \& Viola, G. 2014: Structural and temporal evolution of a reactivated brittle-ductile fault - Part I: Fault architecture, strain localization mechanisms and deformation history. Earth and Planetary Science Letters 407, 205-220. https://doi.org/10.1016/j.eps1.2014.09.019.

Torgersen, E., Viola, G., Zwingmann, H. \& Harris, C. 2014: Structural and temporal evolution of a reactivated brittle-ductile fault - Part II: Timing of fault initiation and reactivation by $\mathrm{K}-\mathrm{Ar}$ dating of synkinematic illite/muscovite. Earth and Planetary Science Letters 407, 221-233. https://doi.org/10.1016/j.epsl.2014.09.031.

Torgersen, E., Viola, G. \& Sandstad, J.S. 2015: Revised structure and stratigraphy of the northwestern Repparfjord Tectonic Window, northern Norway. Norwegian Journal of Geology 95, 397-422. https://doi.org/10.17850/njg95-3-06.

Townsend, C. 1987a: The inner shelf of North Cape, Norway and its implications for the Baretns Shelf-Finnmark Caledonide boundary. Norwegian Journal of Geology 67, 151-153.

Townsend, C. 1987b: Thrust transport directions and thrust sheet restoration in the Caledonides of Finnmark, North Norway. Journal of Structural Geology 9, 345-352. https://doi.org/10.1016/0191-8141(87)90057-5.

Vermilye, J.M. \& Scholz, C.H. 1988: The process zone: A microstructural view of fault growth. Journal of Geophysical Research 103, 12223-12237. https://doi.org/10.1029/98JB00957.

Vorren, T., Kristoffersen, Y. \& Andreassen, K. 1986: Geology of the inner shelf west of North Cape, Norway. Norwegian Journal of Geology 66, 99-105.

Wilks, W.J. \& Cuthbert, S.J. 1994: The evolution of the Hornelen Basin detachment system western Norway: implications for the style of late orogenic extension in the southern Scandinavian Caledonides. Tectonophysics 238, 1-30. https://doi.org/10.1016/0040-1951(94)90047-7.

Worthing, M.A. 1984: Fracture patterns on Eastern Seiland, North Norway and their possible Relationship to Regional Faulting. Geological Survey of Norway Bulletin 398, 35-41.

Zwaan, K.B. 1995: Geology of the West Troms Basement Complex, northern Norway, with emphasis on the Senja Shear Belt: a preliminary account. Geological Survey of Norway Bulletin 427, 33-36.

Zwaan, K.B. \& Gautier, A.M. 1980: Alta and Gargia. Description of the geological maps (AMS-M711) 18341 and 1934 IV 1:50 000. Geological Survey of Norway 357, 1-47.

Zwaan, K.B. \& Roberts, D. 1978: Tectonostratigraphic Succession and Development of the Finnmarkian Nappe Sequence, North Norway. Geological Survey of Norway 343, 53-71.

Zwaan, K.B., Bakke, I., Cramer, J.J. \& Ryghaug, P. 1987: Rotsund berggrunnskart $1634 \mathrm{I}$, scale

1:50,000, Geological Survey of Norway. 
